\title{
日本直腸肛門病學會雜誌
}

第 一 第 二號昭和十五年十二月 (1940)

原著

-内面腸静脈對就中直腸肛門部，静脈二 於ヶル形成體ノ解剖及ビ病理組織學的 䂺焭並二之二基ク痔核, 觀察

第 2 編 哺乳動物ノ内直腸静脈琩特二 痔静脈摭大累束二就テ

醫學博士山本八治

目次
1. 緒官
2. 材料及ビ方法
3. 解剖所見
4. 總. 括
5. 絬 論

1. 緒言

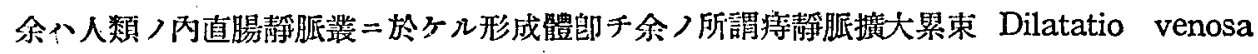

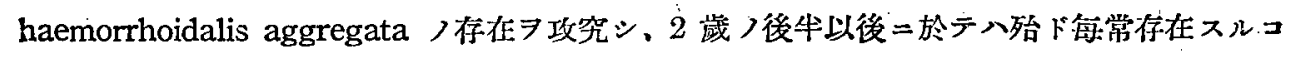

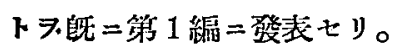

從來哺乳動物ノ內直腸靜脈叢二關シ Bolk, Ellenberger, Martin, Gegenbaur, Perényi, Bensley, Schimkewitsch, Phohle, Schmitz, Stromsten 等ノ動物學並二器醫解剖學ノ文献

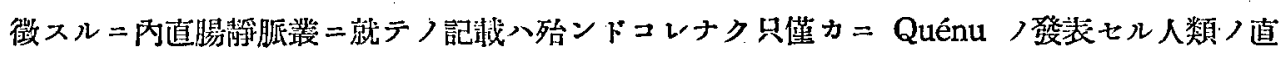

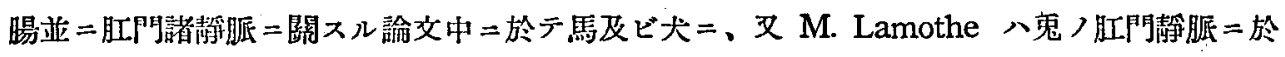

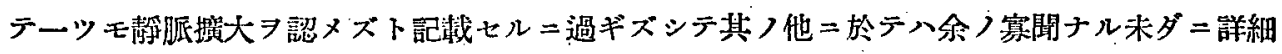
ナル記述アルラ知ラザルナリ。

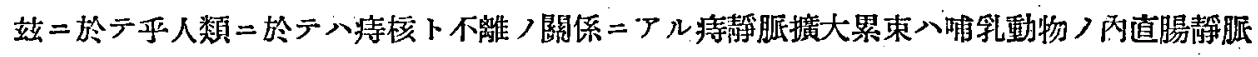

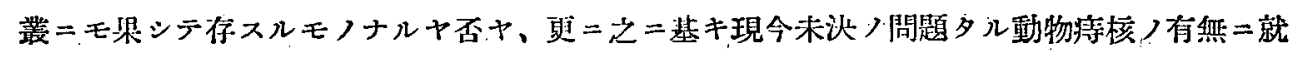

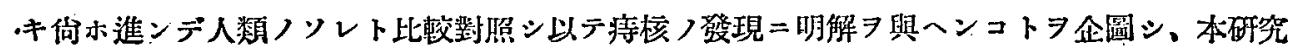


二從事シタル所聊カ其つ成果

\section{2. 材料及ビ方法}

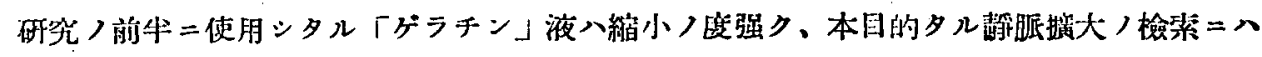
適七ザリシニヨリ之ヨ除外シ、總テタイヒマン氏變法液习注入シタル材料习探用七リ。 材料

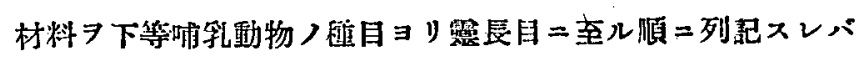

1. 目、Marsupialia 有袋類

亞目、Phytophaga 令荤有袋類

Macropus giganteus 更格啹

2. 目、 Cetacea 鯨類

亞目、Mystacoceti 䞄鯨類

Balaenoptera borealis 魾鯨

3. 目、Perissodactyla 奇䟹類

Equus caballus 馬

4. 目、Artiodactyla 偶蹄類

亞目、Ruminantia 反贸類

Bos taurus 牛

Cervus nippon 鹿

Ovis aries 羊

Capra hircus 山羊

亞目、Non-ruminantia 不反贸類

Sus leucomystax 㺘

Sus scrofa 豚

5. 目、Rodentia 絜蓠頪

盕目、Duplicidentata 重齿類

Lepus brachyurus 鬼

亞目、Simplicidentata 單蒛類

Eutamias asiaticus 縞丞鼠

Càvia porcellus 游璂
Rattus norvegicus $\mathrm{q}$

6. 目、Insectivora 食蟲類

Erinaceus 蝟

7. 目、Carnivora 食肉類 亞目、Pinnipedia 鯺脚類

Callotaria ursina 溫脑㴊

Zalophus lobatus 海驢

亞目、Fissipedia 肢脚類

Canis familiaris $火$

Vulpes japonicus 狐

Nyctereutes viverrinus 狸

Mustela erminea nippon 舅四

Lutra 水獺

Meles taxus 獾

Felis domestica 猫

F. tigris 虎

F. pardus 豹

Ursus japonicus 熊

8. 目、Primates 㗊長類

亞目、Simiae 猿猴類

Macacus cyclopis 臺棈猿

M. fuscatus 日林猿

Hylobates 手長猿 
方 法

動物ニ於テ一般=使用セラル「ゲラチン：液ニ「カルミン」、「ベルリン青」つ如キ色素习

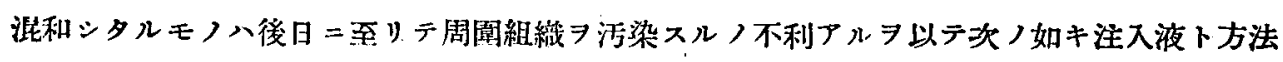
ヨ:迩定ヒり。

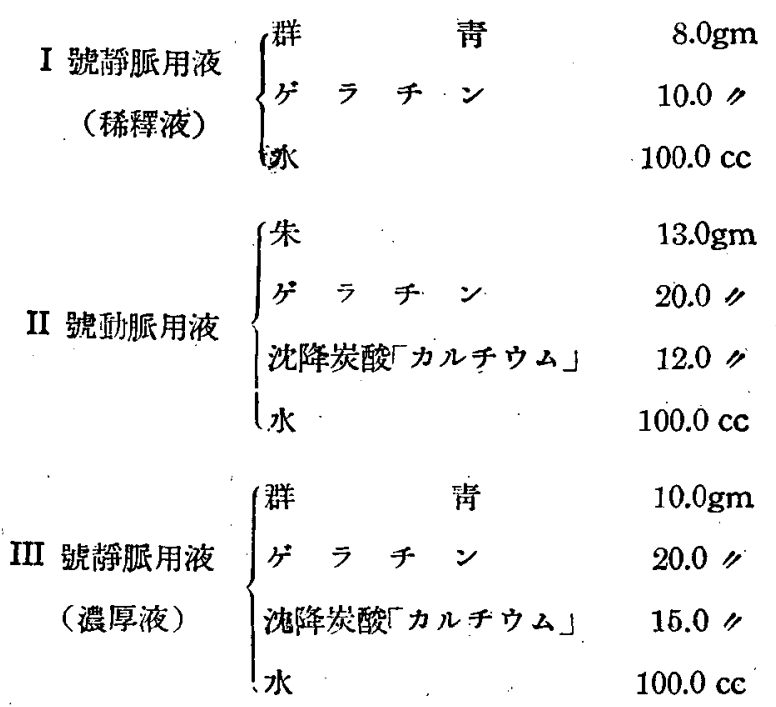

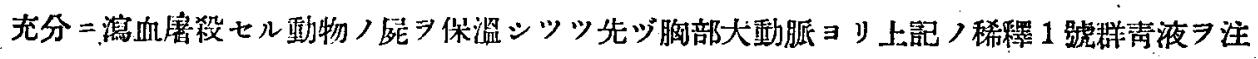

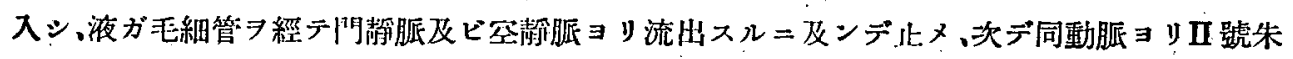

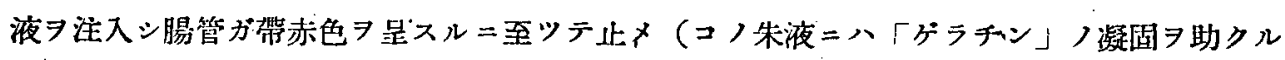
粒子粗大ナル沈降炭酸「カルチウム」ヨ和七ルガ故二假令强照习以站注入スルモヨク毛細管

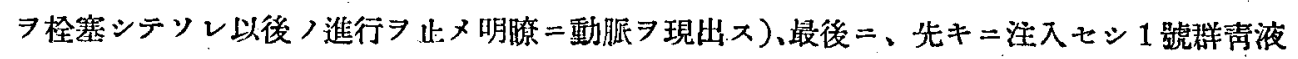

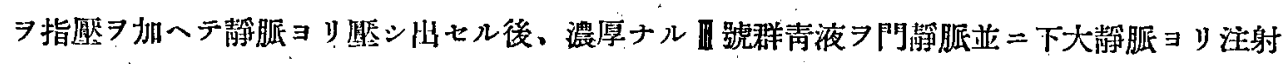
シ、腓管ガ稍ね藍色 ニ投ジテ「ゲラチン」ノ凝回シ圆レリ。則チ斯クシテ辫膜ヨ有スル細微ナル靜脈二至ルマデ 完全二注入スルヨ得テ血管ノ形態习略一定度二現ハス

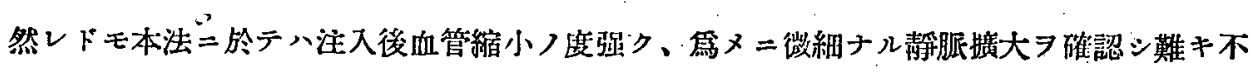

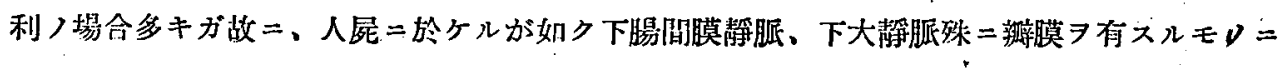
於テハ肛門靜脈ヨリモ余ノ用ヒタルタイヒマンE變法液フ注入セリ（第 1 編）。

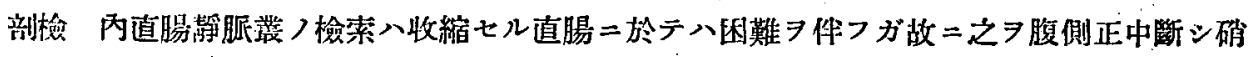

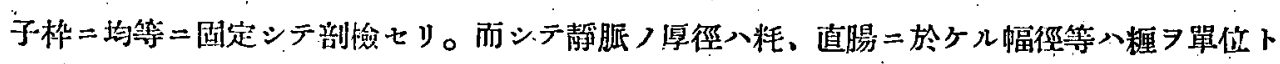
シテ其ノ次二記载ス。

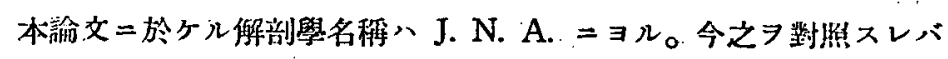


新

\section{J. N. A.}

V. rectalis cranialis 首側道腸靜脈

Vv. anales 肛䢹靜㟲

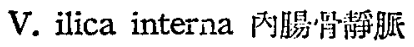

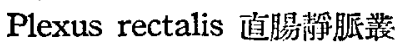

Pars ampullaris 膨大部
鹪

B. N. A.

V. haemorrhoidalis superior 上特靜脈

V. haemorrhoidalis media 中庤静脈

Vv. haemorrhoidalis inferior 下痔靜胍

V. hypogastrica (V. iliaca interna)

Plexus haemorrhoidalis 痔塪脈灇

Ampulla recti 直腸膨大部

新 J. N. A. ニ八 V. haemorrhoidalis media 中㾌静脈八抹殺シフルモ余ハソレニ記阵シ $ア ル$ A. rectalis caudalis 琵側直晹動脈二集ジテ V. rectalis caudalis 尾側直腸静脈ナル名

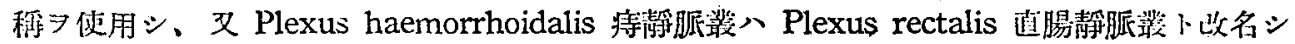

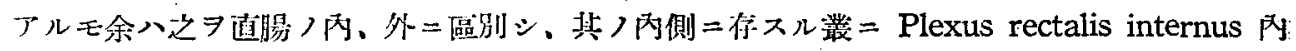

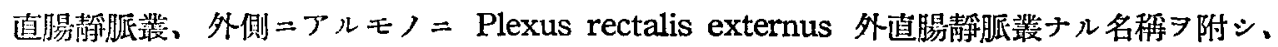

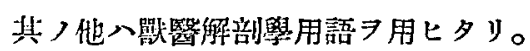

\section{3. 解 剖 所 見}

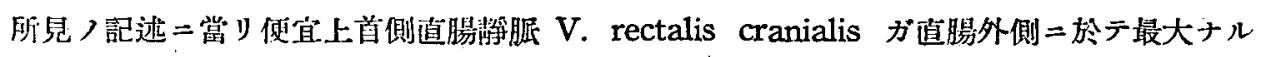

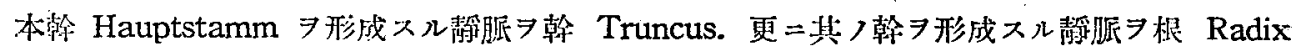

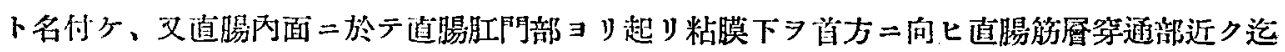

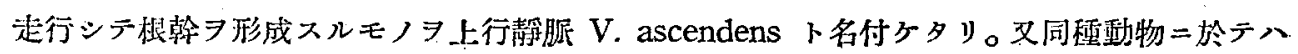

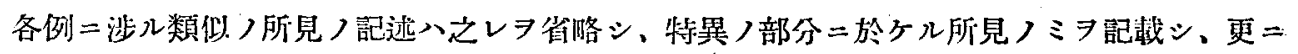

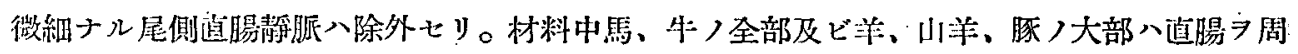

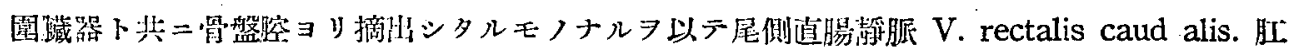

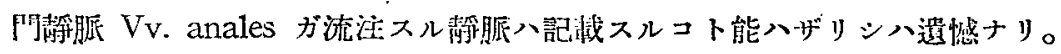

Marsupialia 有袋類

第 1 例 Macropus giganteus. 速格漹

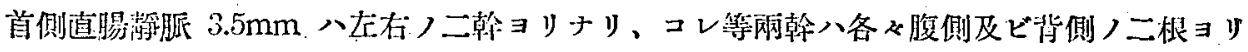
成儿。右翰 Truncus dexter $2.5 \mathrm{~mm}$ 八腹侧根 Radix ventralis 八遖晹肚坷部 Pars analis

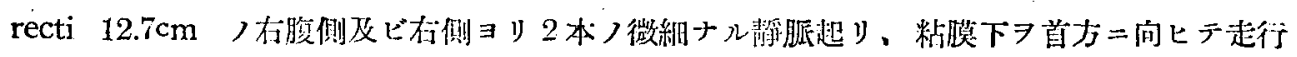

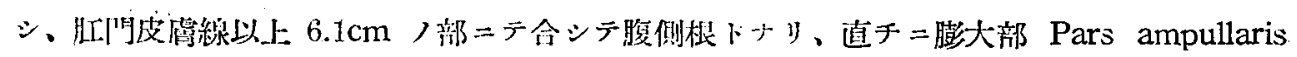

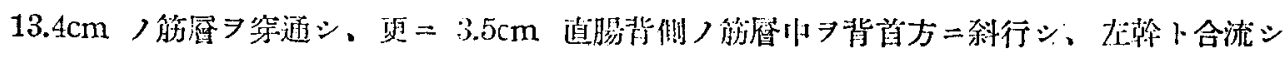

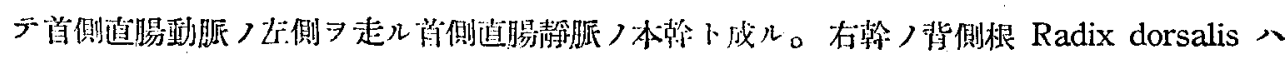




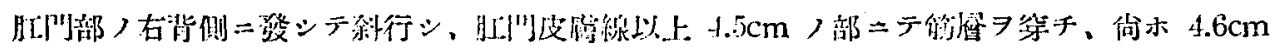

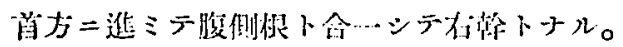

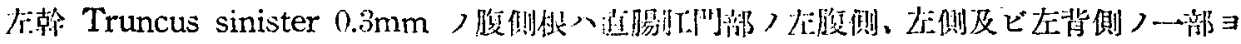

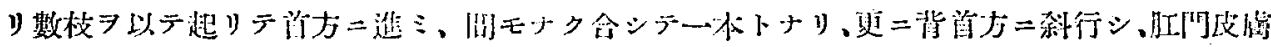

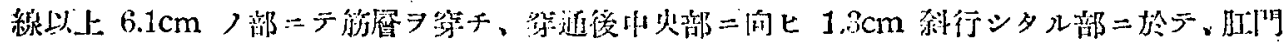

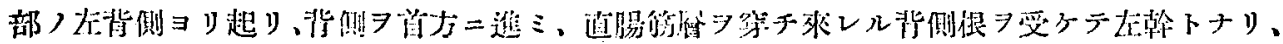

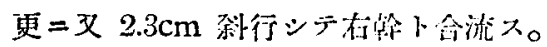

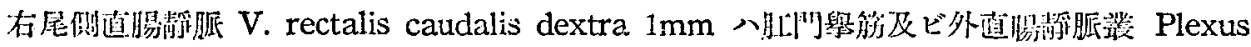

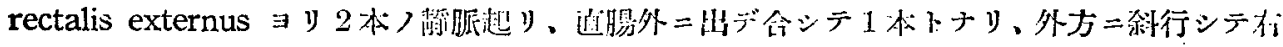

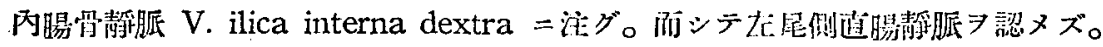

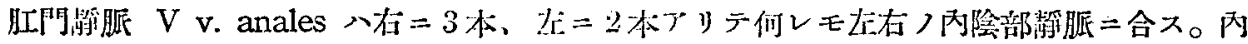

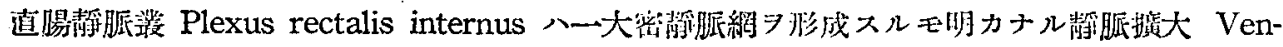

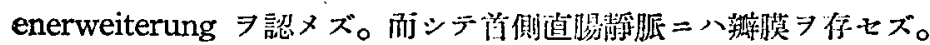

\section{Cetacea 鯨類}

第2 例 Balaenoptera borealis 鯨 우

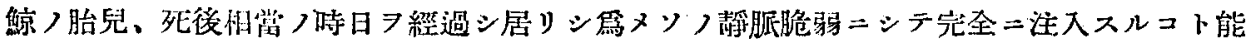

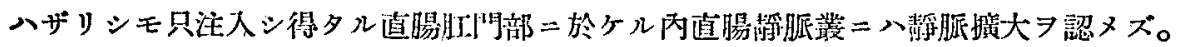

Perissodactyla 奇䟹類

第 3 例 Equus caballus 馬 $\hat{0}$

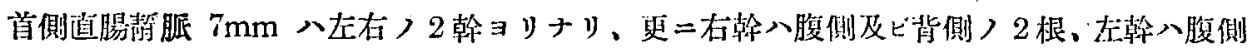
及ビ背側つ 2 本ノ上行鎐脈 $コ$ 成ル。

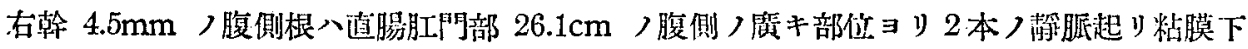

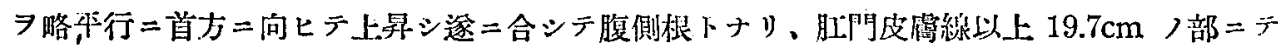

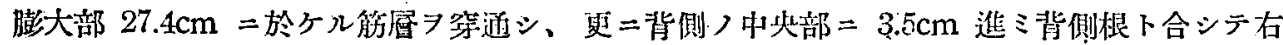
幹トナリ、向ホ $2.9 \mathrm{~cm}$ 同方向二走リテ厺翰ト合シ首側直腸静脈卜ナル。右翰つ背側根八直

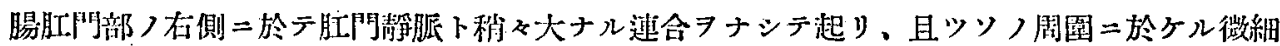

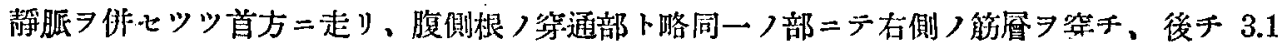
cm 進ミテ腹側根下合流ス。

左幹 $5.1 \mathrm{~mm}$ フ腹例及ビ背側上行靜脈八直腸肛門部ノ右側及ビ背側 $コ$ 微細ナル數枝

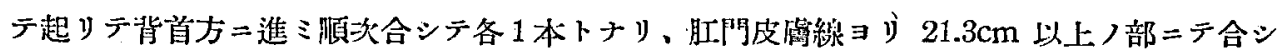
テ左翰トナリ、直チ二道腸筋層习第チ、更二首方ニ $5.8 \mathrm{~cm}$ 走リテ右翰ト合流ス。

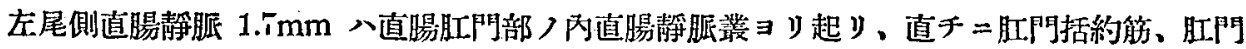


擧管

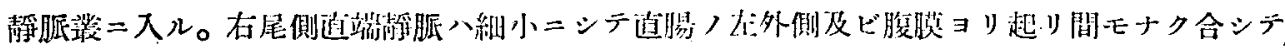

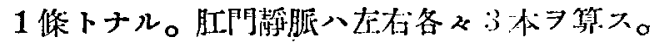

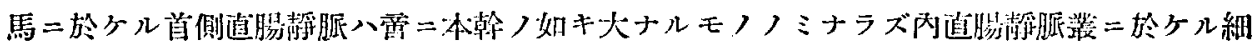

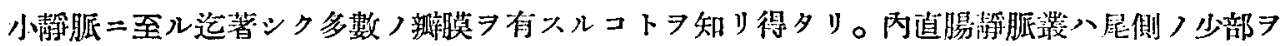

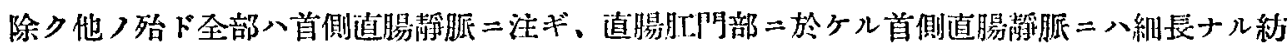

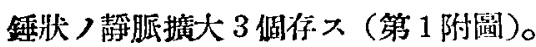

第 4 例 馬

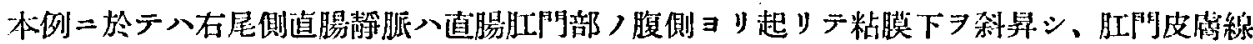

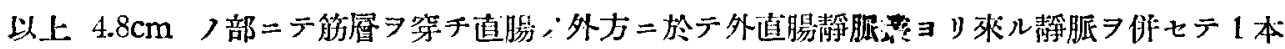

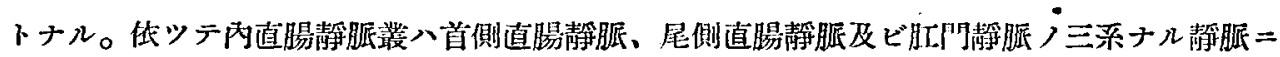

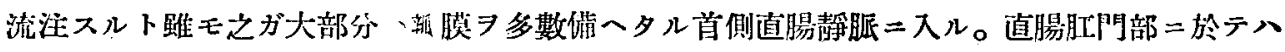

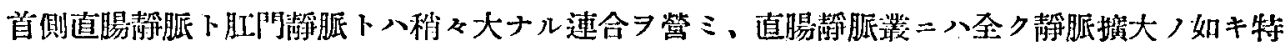
異ノ形成艠ヨ認メズ（第 1 圖)。

第 1 㽞 $\quad$ 馬 $\odot 1 / 3$

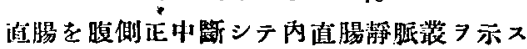

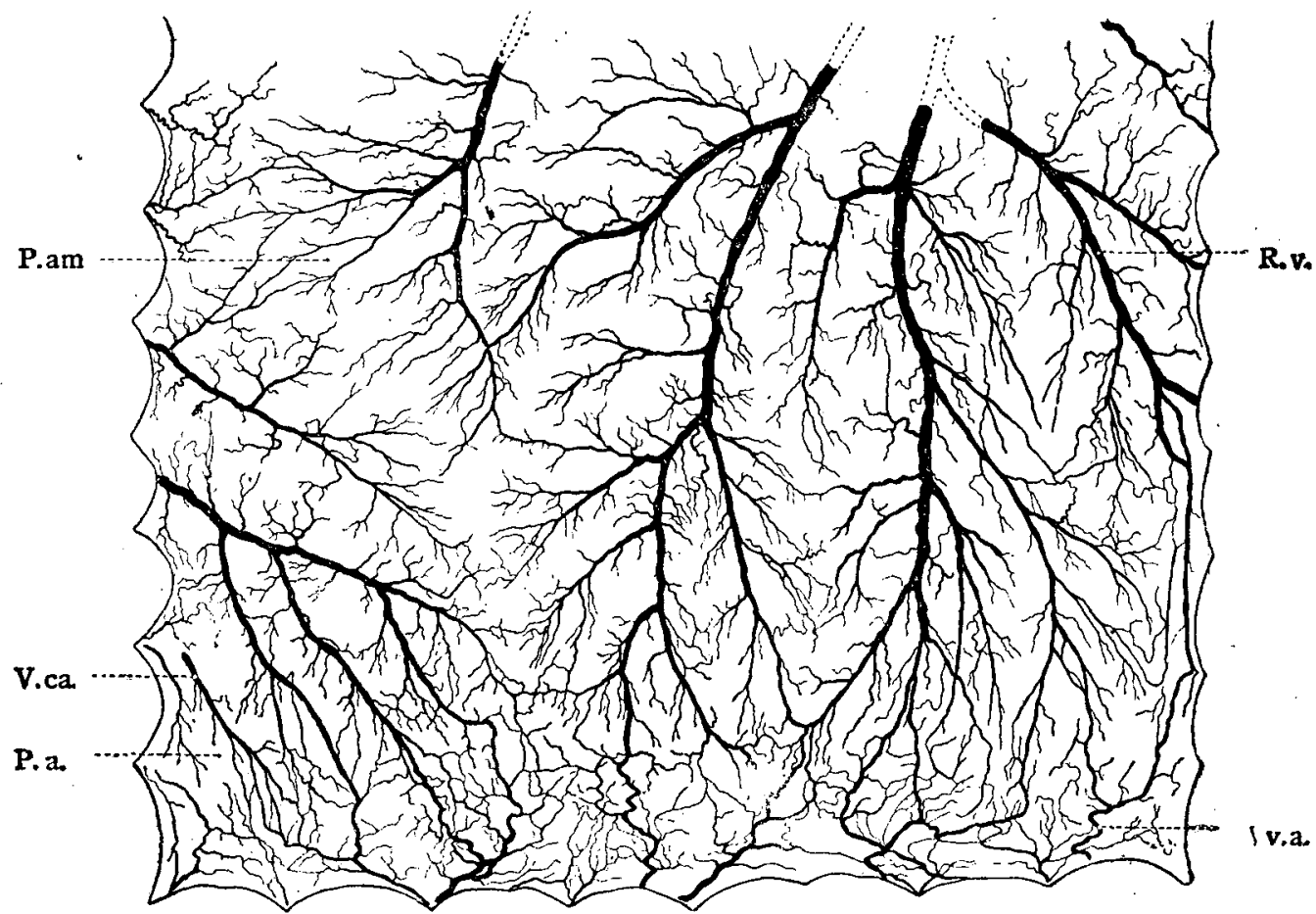

其ノ他䮦 20 檢軆中萻明ナル静脈援大フ認メタルモノ2 頭ナリ。 


\section{日、Artiodactyla 偶蹻類}

严目、Ruminantia 反畾類

第5.例 Bos taurus 牛 9

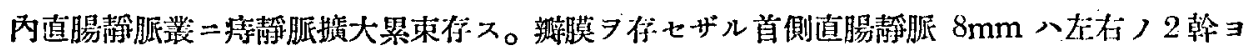
リナリ、更二右翰八腹側及ビ背側ノ 2 根ノ合流ョリ成ル。

右幹 $6 \mathrm{~mm}$ ／腹側根八直腸肛門部 $23.3 \mathrm{~cm}$ /右腹倒ヨリ 3 本ノ細小ナル静脈起リテ首方二

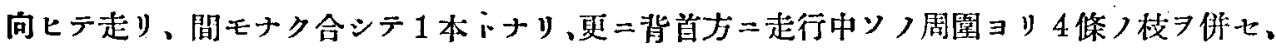

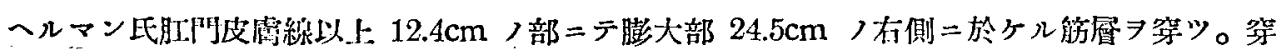
通後 $7.6 \mathrm{~cm}$ ノ部二於テ背側根ト合シテ右幹トナリ、份ホ $2.1 \mathrm{~cm}$ 中央部二進ミ左幹卜合流シ

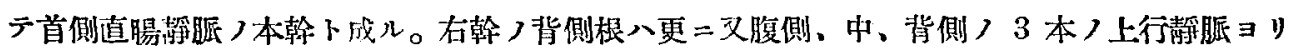
ナル。ソフ腹侧上行靜脈八通腸肌門部ノ右側ヨリ4 小枝發シ、暫時首方二走リタル後合シテ 1 本トナル。中及ビ背側_上行聱脈八肛門部ノ背側部ノ殆ンド全面ヨリ起リ、份ホ又八左側ヨ リモ起り、粘膜下ヨ背側ノ中央部二向七斜二走リ、解層穿通部以下 $1.7 \mathrm{~cm} /$ 部ニテ合シテ

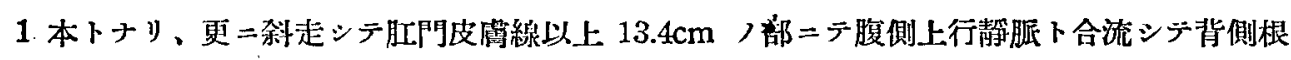

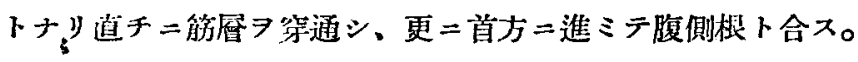

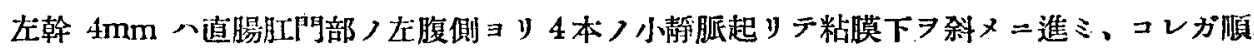

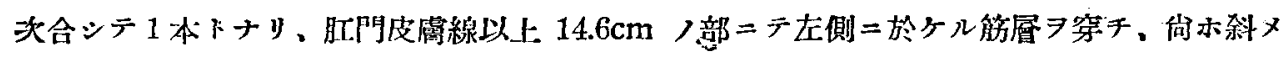
$=$ 首方 $=8.4 \mathrm{~cm}$ 走リテ右翰卜合一ス。

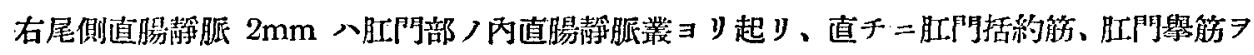

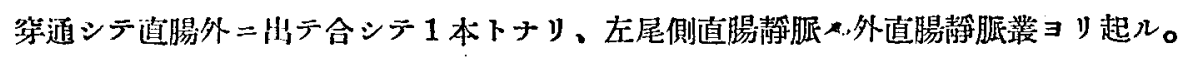

肚門靜脈八左右各《 3 條アリ。

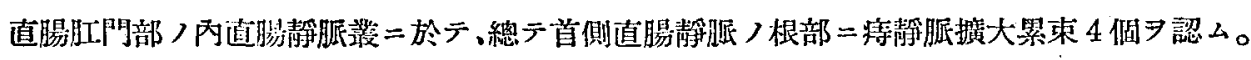
之ヨ形成セ儿静胍掂大八右腹部ノ夫レ $=8$ 個、右ノ夫レ $=5$ 個、背側ノ夫レ $=6$ 個及ビ左腹

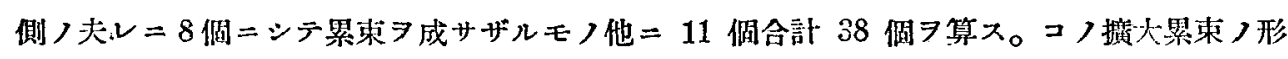

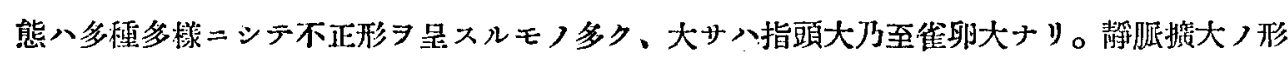
狀モ亦種ふアレドモ形八細長ナル紡鍾桀，大サ小豆大ノモノ最モ多シ（第2附圖)。

第 6 例 牛 8

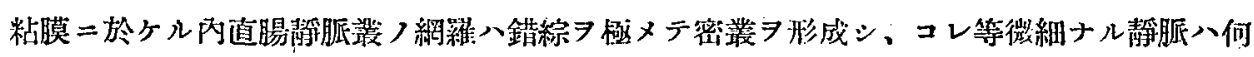

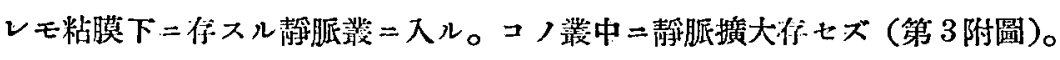

第7例 牛 $\hat{o}$ 生後 1 万月

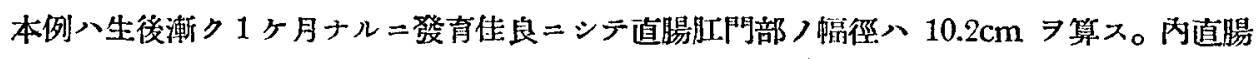

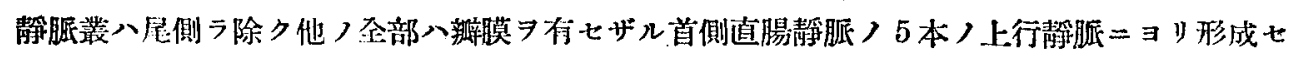




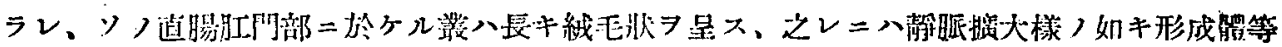
ヨ金ク㖊メズ (旌 2 圆)。

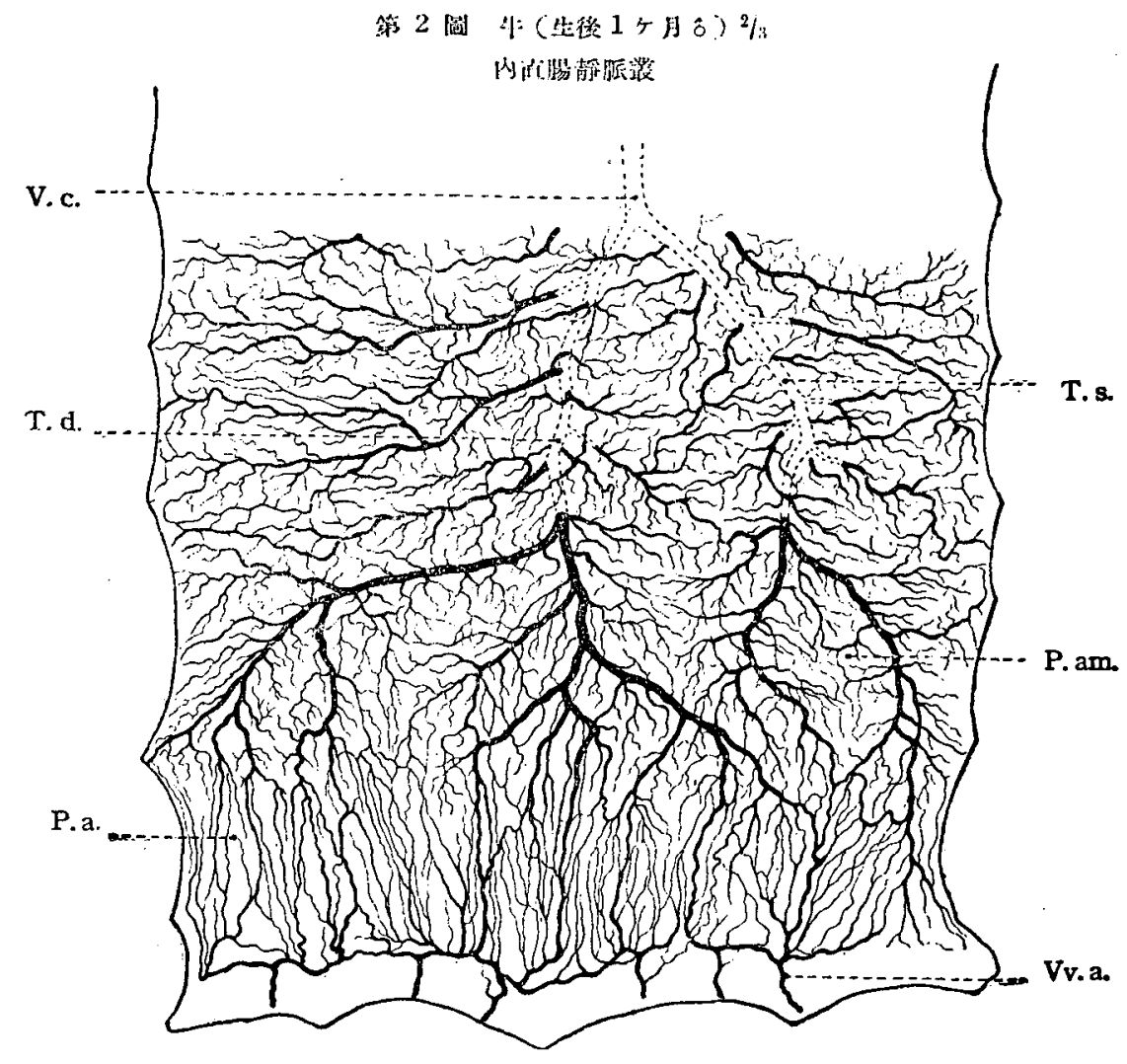

第8例 牛 $\hat{0}$ 生後 4 ケ月

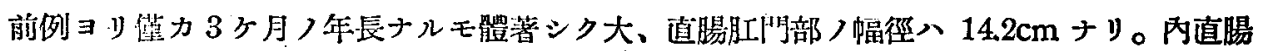

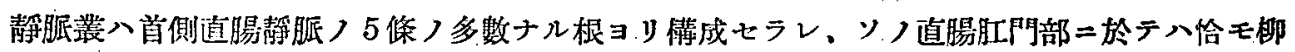
枝狀

第 9 例 牛 8

本例八發䏍完成七ル牛ニシテ直腸肛門部ノ幅徑ハ $23.5 \mathrm{~cm} ７$ 算ス。

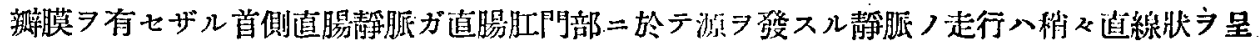

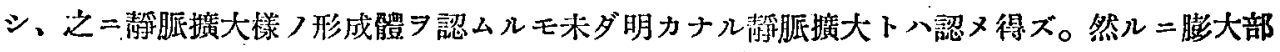
ニ於テハ單ナル絧狀ヨ構成スルノミニシテ直腸肛門部ニ於ケル夫レト聊カ其ノ趣 フ異ニス。

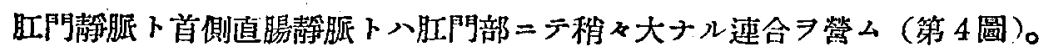




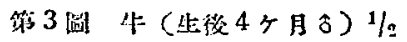

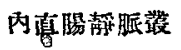
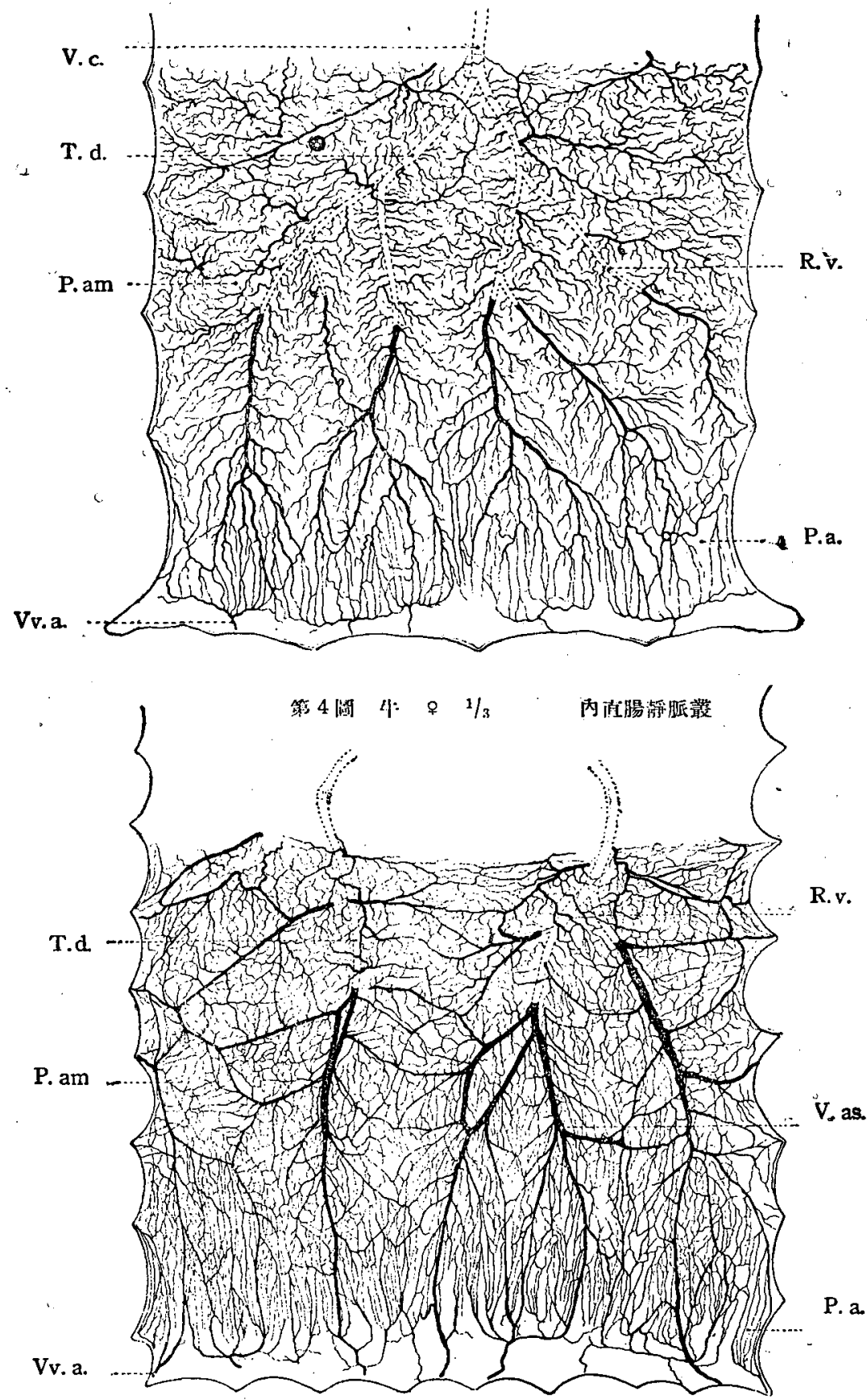

第10例 牛 $\hat{o}$

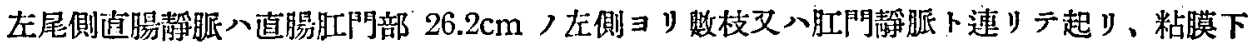

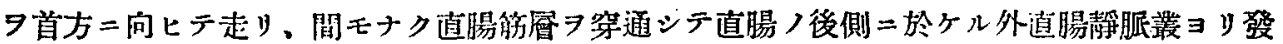




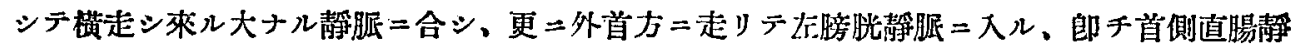

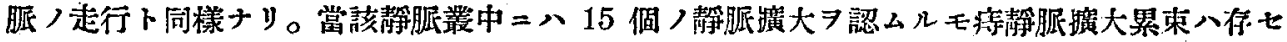
ズ(第 5 圆)。

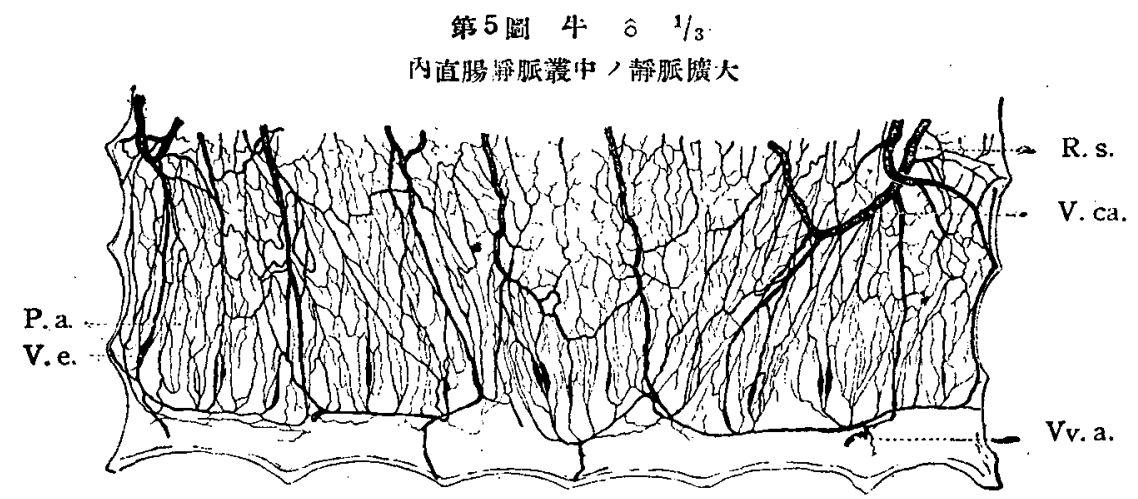

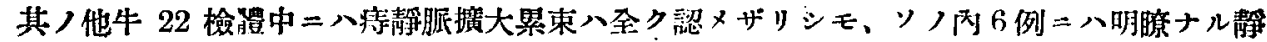
眼擴大フ存スルラ見タリ。

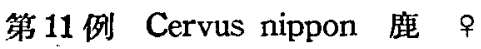

首側直腸靜脈 $3.0 \mathrm{~mm}$ 八左右及ビ中， 3 翰

中幹 $2.5 \mathrm{~mm}$ /右根八遖腸肍門部 $14.0 \mathrm{~cm}$ /右及ビ右背唰、方根八同部ノ左及ビ左背側

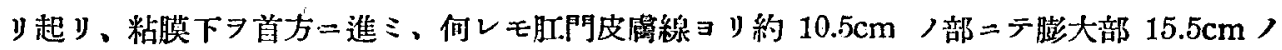
能震 7 第通シ、兩者共約 $4.0 \mathrm{~cm}$ 中央部二向ヒテ走リ、合シテ中翰トナリ、更 $=1.8 \mathrm{~cm}$ 進ミ 左右兩幹卜合流シデ首側直腸静脈ノ本幹卜成儿。

右幹 $2.2 \mathrm{~mm}$ 八肚門部ノ右側及ビ标背側ヨリ起り、背首方二斜行シテ肍門皮膚線以上 11 .

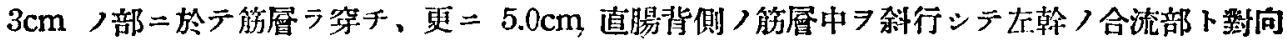
シテ中翰ニ注グ。

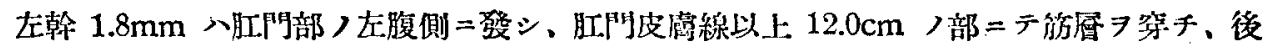

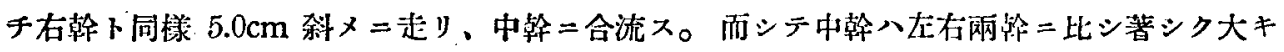

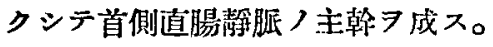

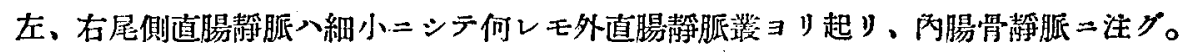

肛門靜脈八左有各ヶ 3 本

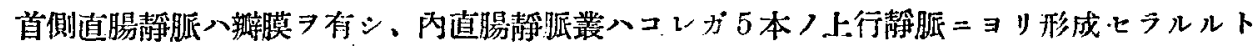

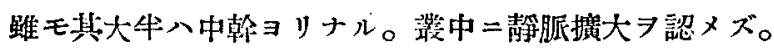

第 12 例 Ovis aries 羊。

首側遖腸靜脈 $3.5 \mathrm{~mm}$ 八后 2 幹, 合流 $コ$ 成几。 
右幹 $2.5 \mathrm{~mm}$ 八直腸肍門部 $11.3 \mathrm{~cm}$ ）右腹側及ビ右側ヨリ多數つ小枝起りテ首方二進ミ。

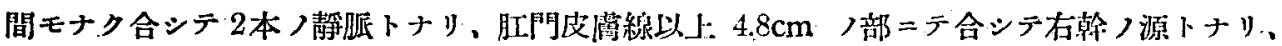

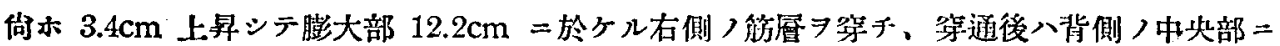
向七更 $=2.7 \mathrm{~cm}$ 走りテ灰幹ト合一シテ首側直腸靜服ノ本翰卜ナル。

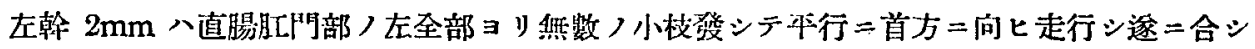

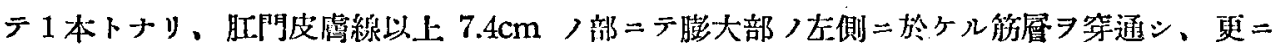
背首方 $=3.9 \mathrm{~cm}$ 進ミテ右幹卜合ス。

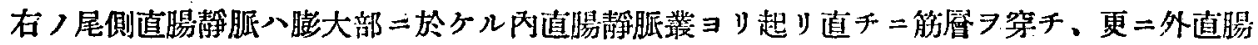

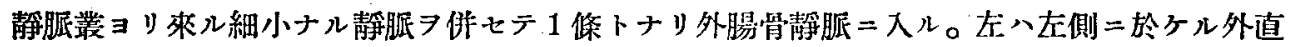
腸靜脈丵 $=$ 源

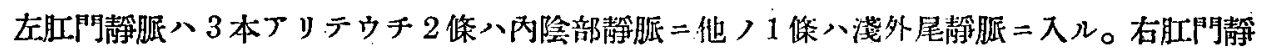
脈八 1 本习算シ右內陰部靜服二入ル。

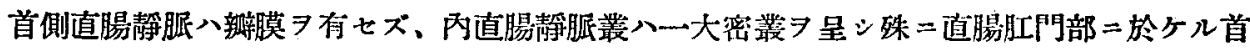

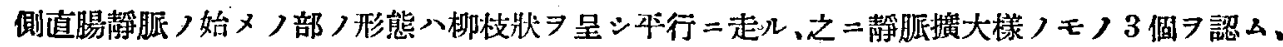

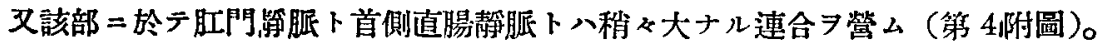
第13 例 羊 0

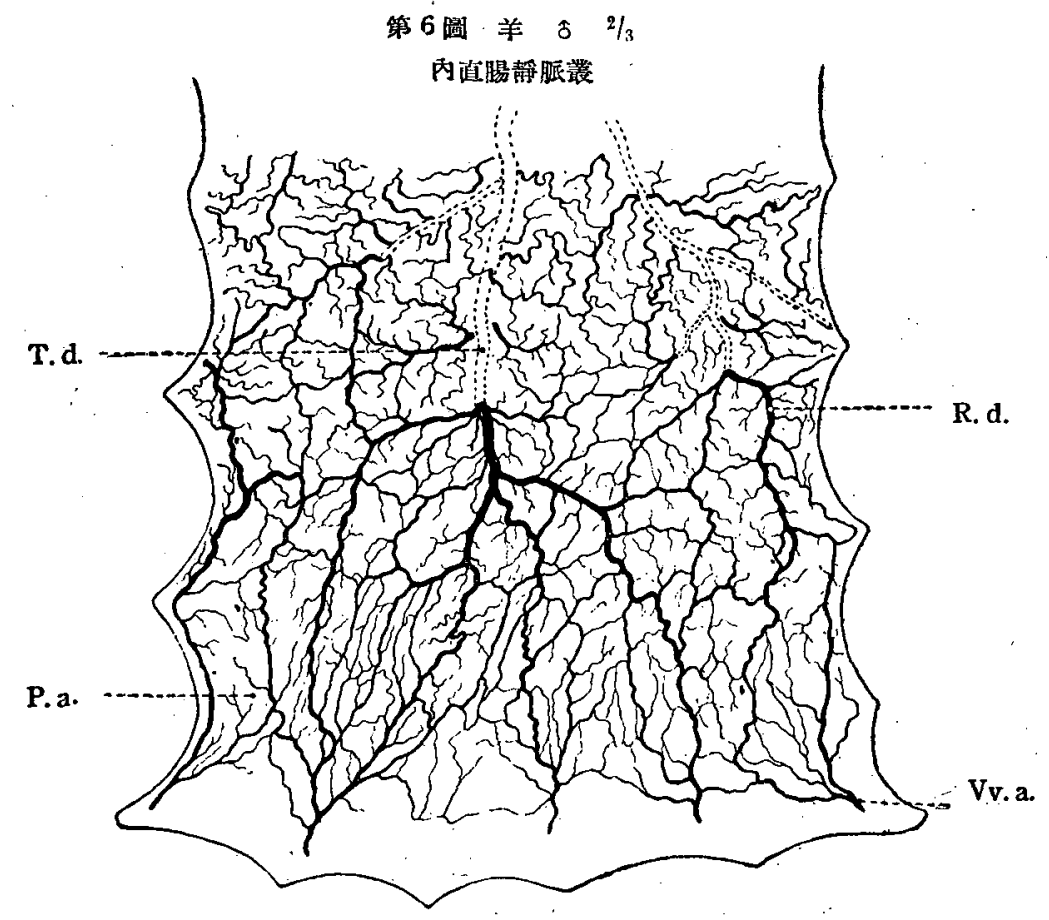




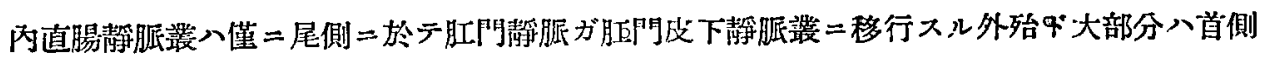

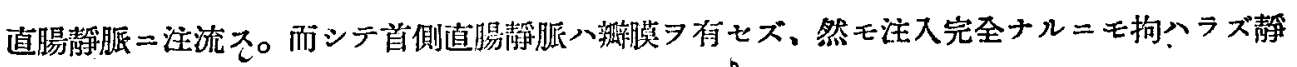

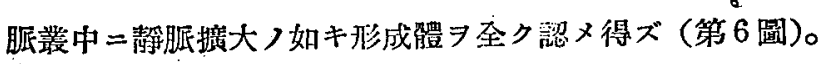

第 14 例 Capra hircus 山羊 $0^{\circ}$

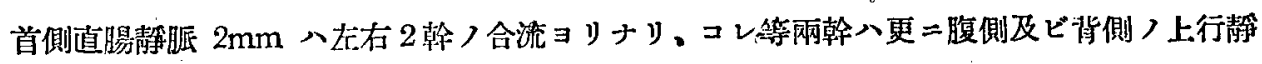
胍 $\exists$ !成儿。

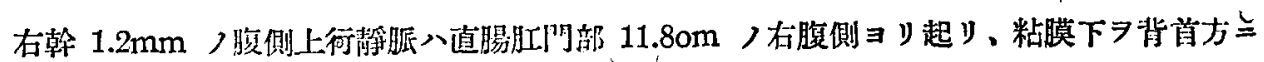

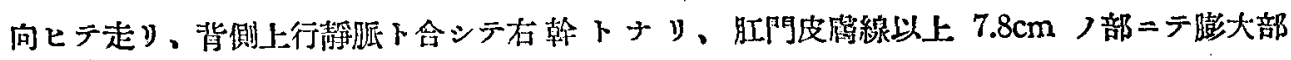

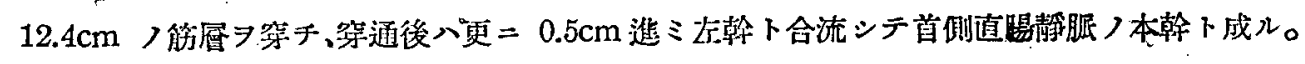

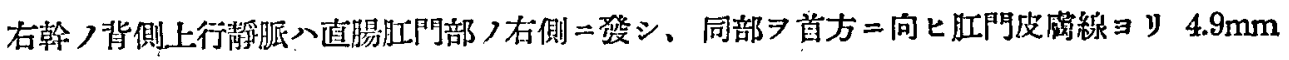
進ミテ腹倒上行靜脈的合ス。

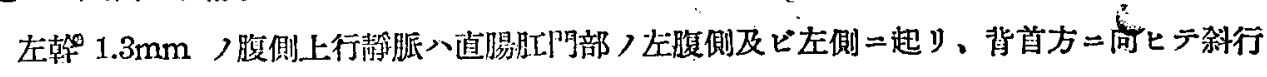
シ、肛門皮虞線以上 $5.3 \mathrm{~cm} /$ 部ニテ背側上行靜脈ト合シテ左幹トナリ、更 $=2.0 \mathrm{~cm}$ 走行ン テ道腸筋尿

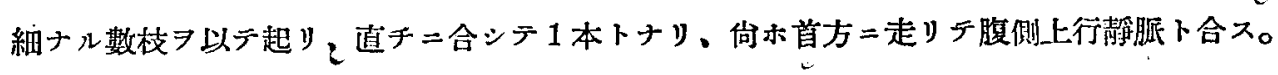

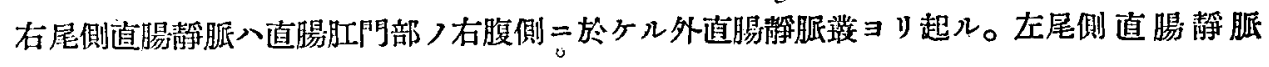

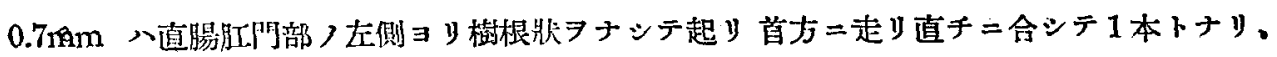

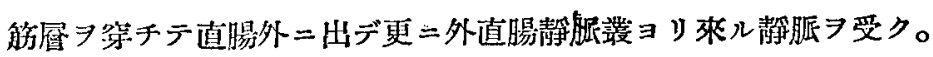

肛門塪脈入数入左右各え 3 條存ス。

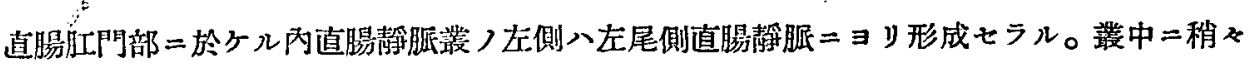

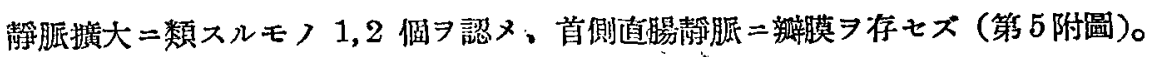

第 15 例 山羊 8

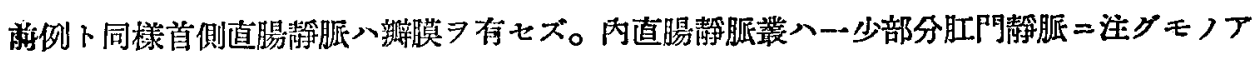

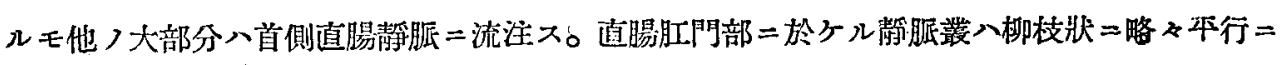

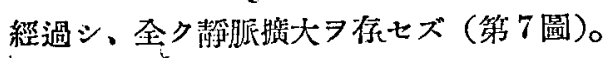

亞目、Non-ruminantia 不反鹤類

第 16 制 Sus leucomystax 狅 $\hat{0}$

首側遖腸等胍 $2.5 \mathrm{~mm}$ 八左存ノ 2 翰 $コ$ 成ル。

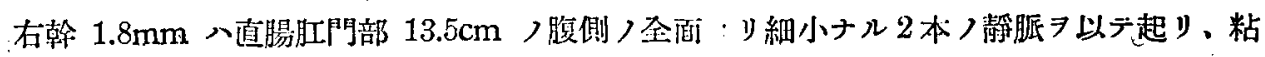
瞙下シ走リ合シテ 1 低つ右翰トナリ、更二自背方二向と肛門皮線ヨリ $8.2 \mathrm{~cm}$ 科走シテ膨大

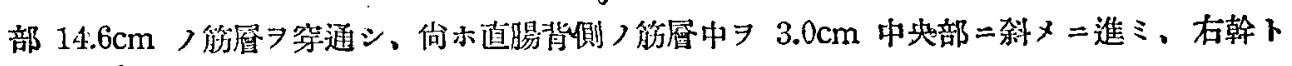
合流シテ首側直腸動脈〉右側ヨ走ル首側直腸靜脈ノ本幹卜成ル。 


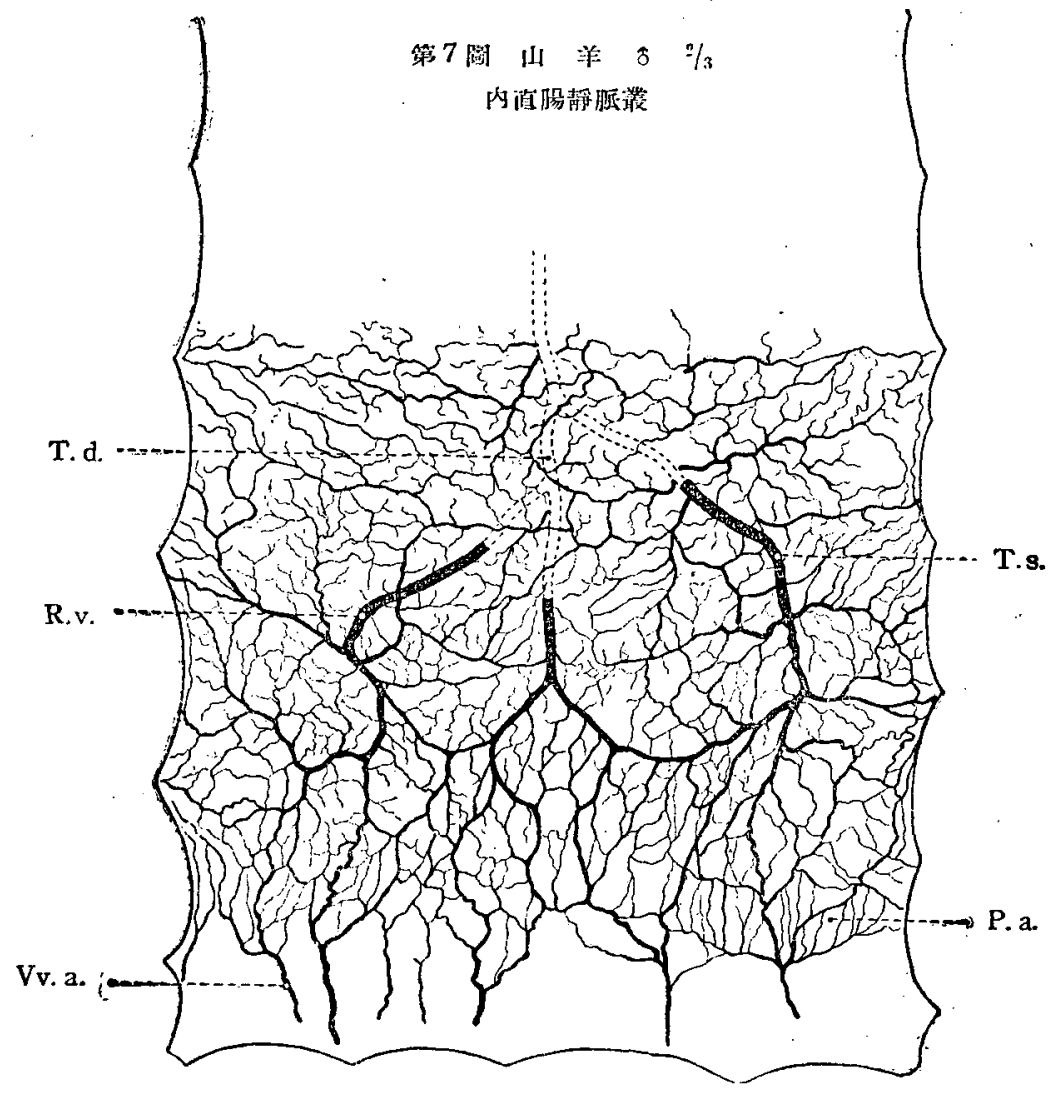

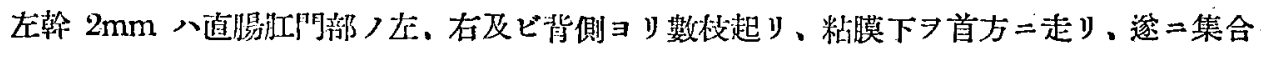

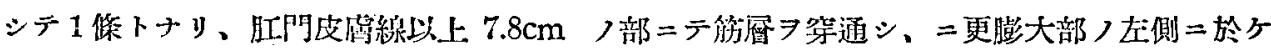

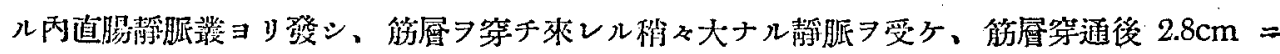
シテ左翰ト合流ス。

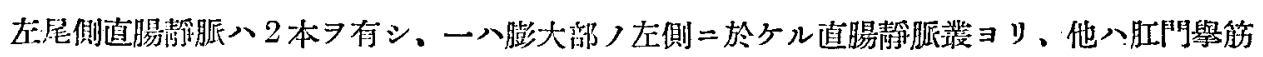

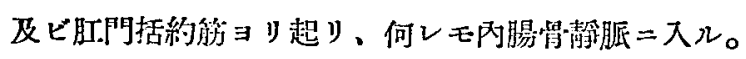

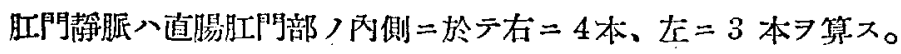

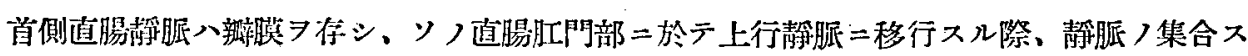
ルノ跃八樹根狀

第 17 例 Sus scrofa 豚

本例二於アル豚八發青佳良、體重八甚ダ大ニシテ、首側直晹靜脈二八瓣膜 直腊偁脈 $7 \mathrm{~mm}$ 八左右ノ 2 幹 $\exists リ$ 成り、更二左幹八腹側、中、背側ノ 3 根、右幹八腹側及 ビ背側ノ 2 根ノ合流 $コ$ 成立ス。

左幹 $5 \mathrm{~mm}$ ，腹側根八直腸肛門部 $25.0 \mathrm{~cm} /$ 左腹側、中根八左側、背側根八左背側二起 リ 何レモ粘膜下ヨ首方二向ヒテ昇り、前者八肚門皮處線以上 $15.5 \mathrm{~cm}$ 、中者八 $12.6 \mathrm{~cm}$ 、後者八 


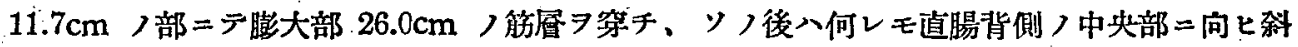
行シ。傾次三者集合シテ 1 條ノ左幹 形成シ、背側根 /能層穿通部 $コ 11.0 \mathrm{~cm} /$ 部二テ右

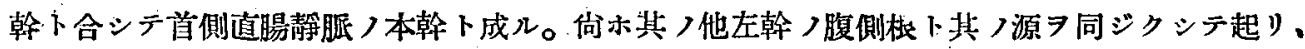
左腹側部

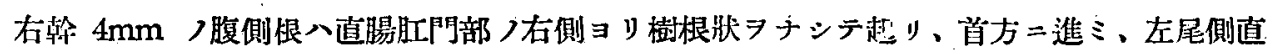

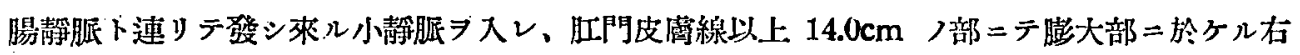
側 つ䇟磨 進ミ左幹卜合流ス。右幹)背側根入右背側二起リテ首方二走リ、佁ホソ，周圍つ微細ナル枝

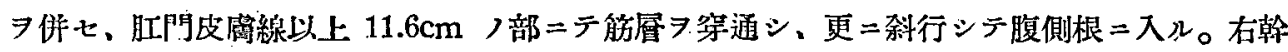
八更二右尾側直腸靜脈下蓮合シ來ルモノ及ビ膨大部ノ右腹側ニ於ケル內直腸静脈丵ヨリ集合 シ來儿側副靜脈フ受ク。

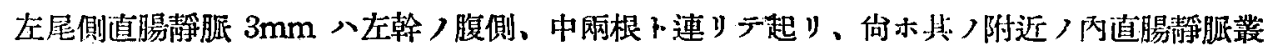

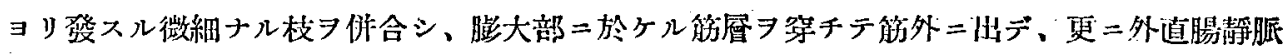

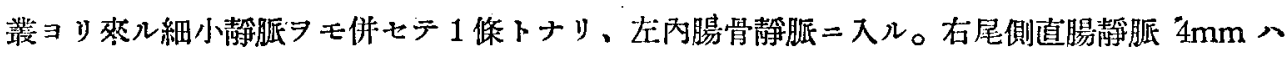

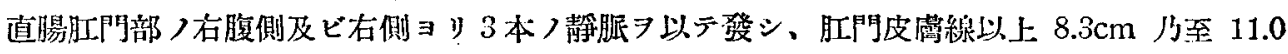

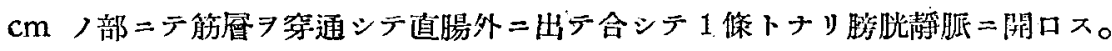

肚門静脈八右 $=4$ 保、太 $=3$ 保アソ。

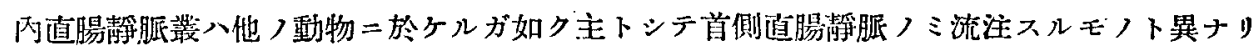

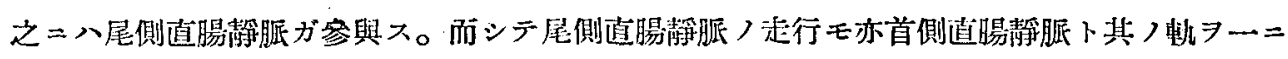

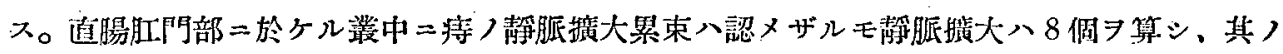

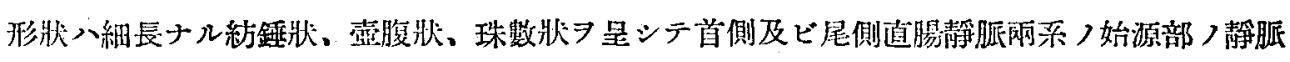

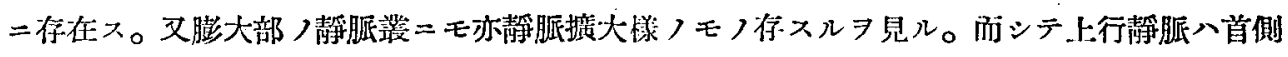

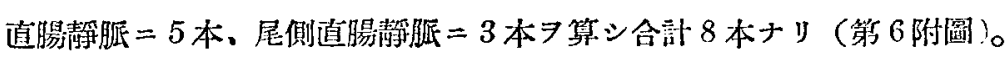

第 18 例 㟲 ?

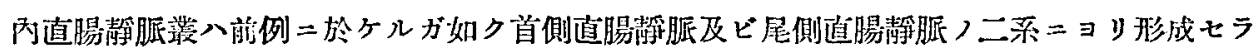

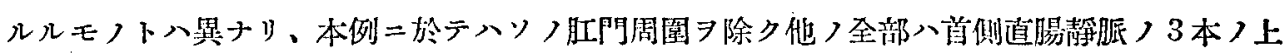

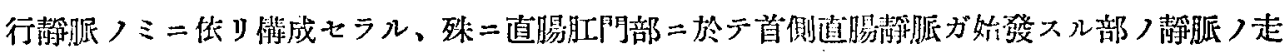

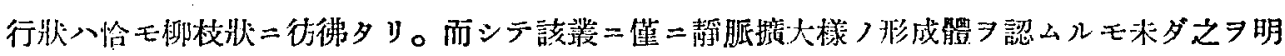
カナル擴大ナリト見做シ得ズ (第 8 圖)。

第 19 例 腺 $\hat{0}$

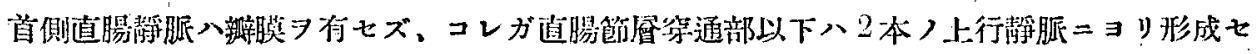

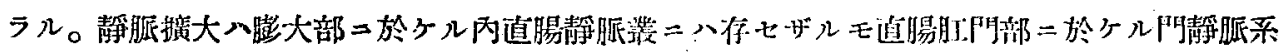




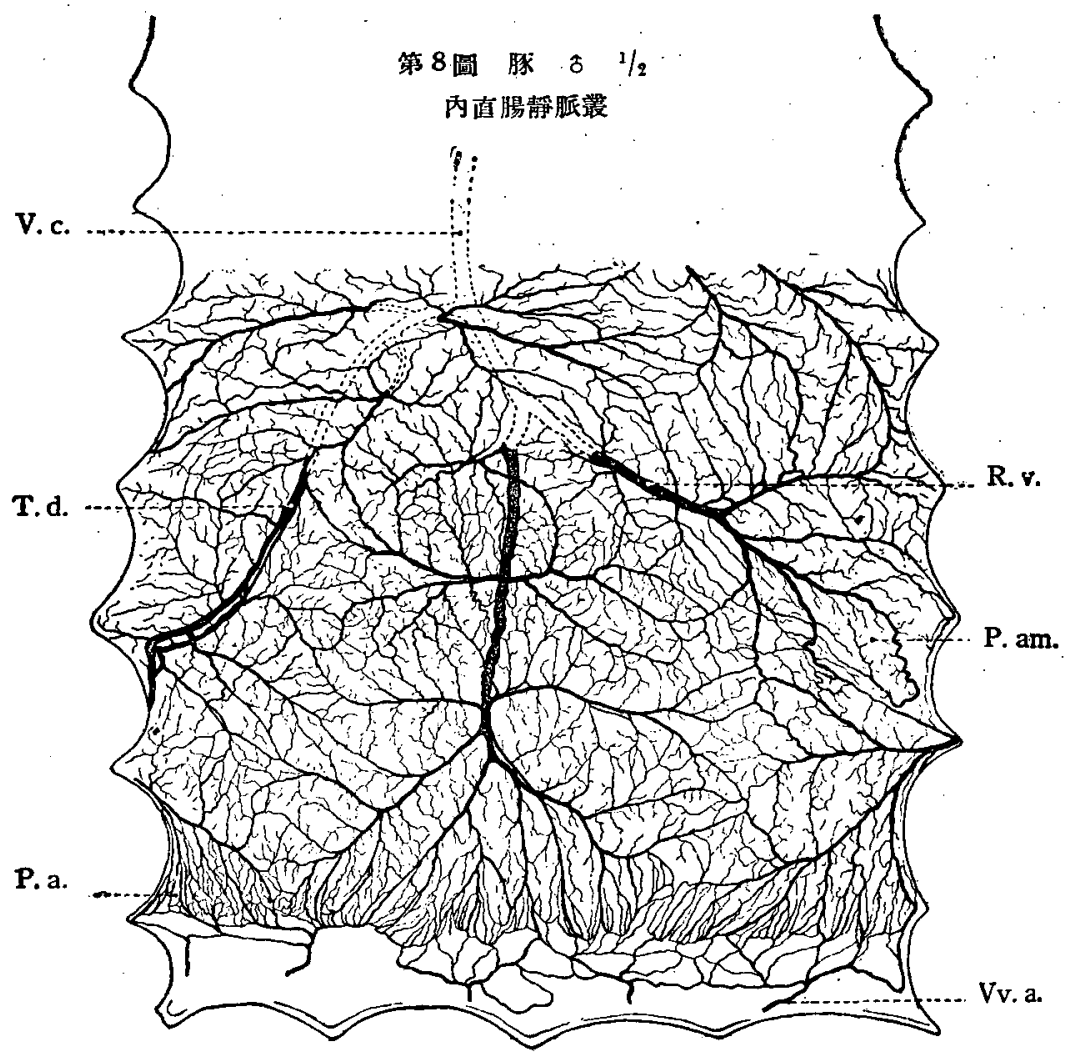

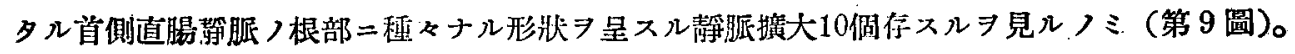
其ノ他趼 15 檢體中明カナル静呱擴大

\section{Rodentia 掏齿類}

\section{Duplicidentata 重齔類}

第 20 例 Lepus brachyurus 鬼 $\hat{8}$

首側直腸靜脈 $1.2 \mathrm{~mm}$ 八膨大部ノ右側二位スル主幹ノ延長ナリ。

主幹 $1.1 \mathrm{~mm}$ 八直胑肛門部 $3.1 \mathrm{~cm}$ ノ左腹側、左及ビ背側全部ョリ4 本ノ微細ナル静脈起り、 粘膜下 $ヨ$ 左腹側 =向ヒテ科行シ、コレ等が㮌次集合シテ 1 本トナリ、在腹側ア迁曲シテ右尾

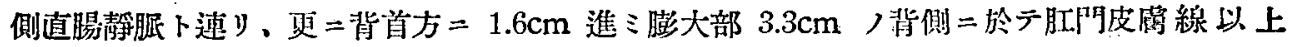

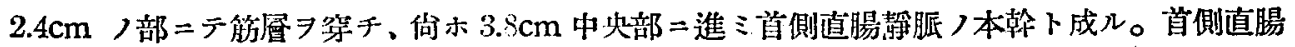

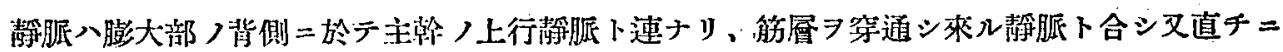
岐レテ左右ノ2 條トナリ、直腸後方ノ中央部 $3.7 \mathrm{~cm}$ 通走シ、再ビ合流シテ 1 佟トナル。

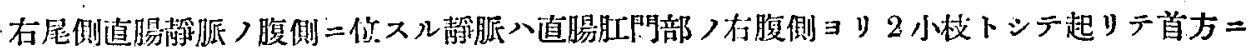

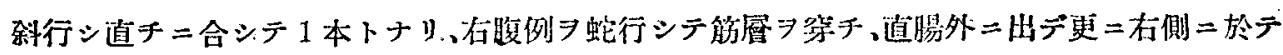

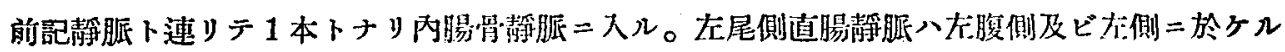


第 9 腈家

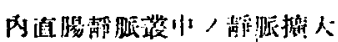

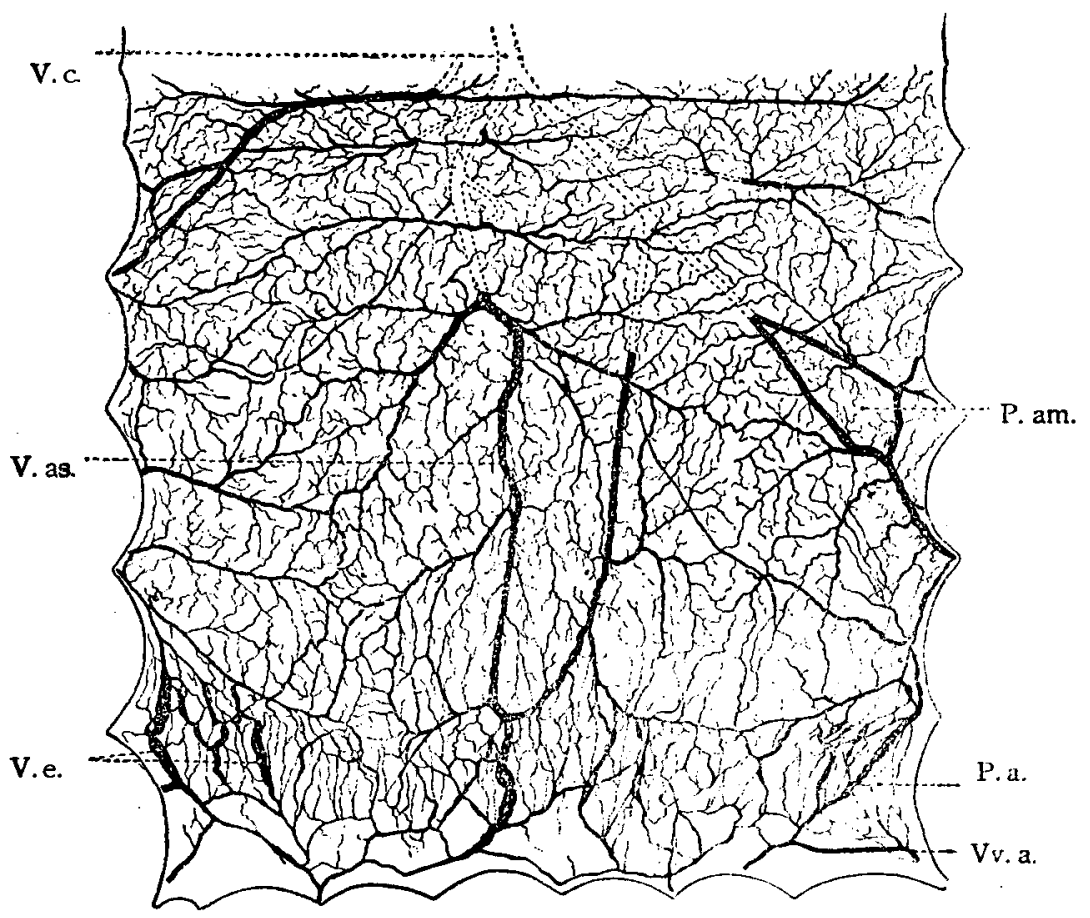

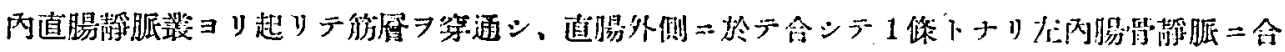
$x_{0}$

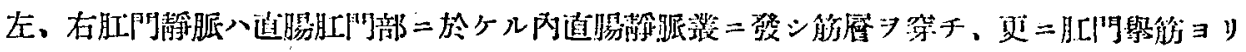
來儿埥脈下合シテ內陰部静脈二入ル。

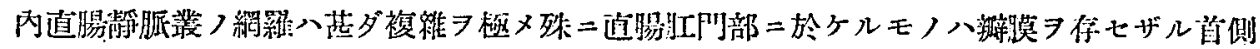

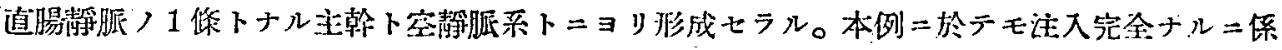
ハラズ全ク靜脈攐大ヨ認メズ(第 7 附圖)。

\section{亞目、Simplicidentata}

第21例 Eutamias asiaticus 縞喿鼠 \%

首側通腸靜胍 $0.4 \mathrm{~mm}$ 八左。中及ビ右ノ 3 翰ヨリ成リ、更二中翰八左、右，上行靜胍，合 流ヨリナル。

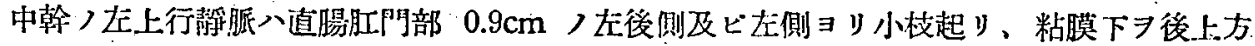

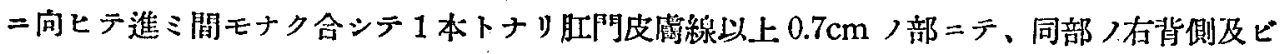

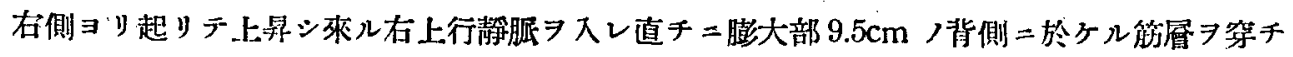




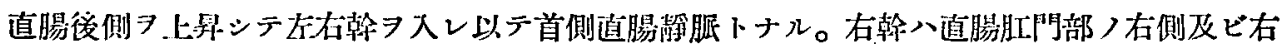

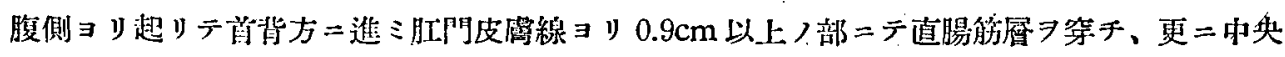

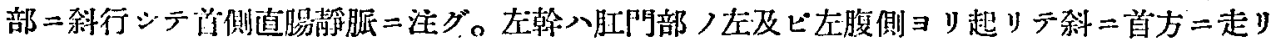

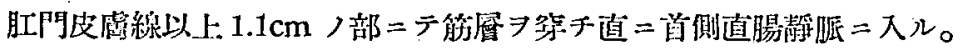

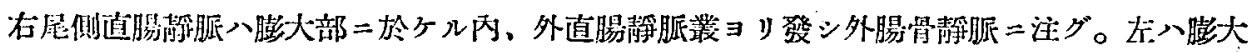

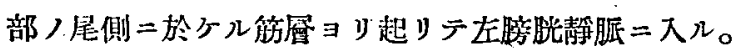

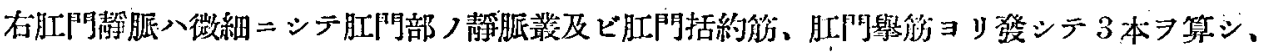

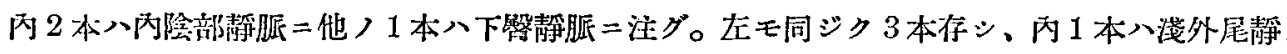

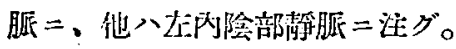

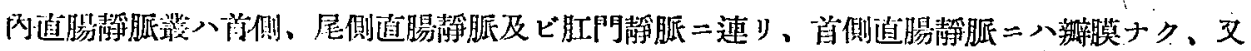

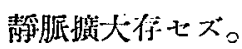

第22例 Cavia porcellus 湤猽 8

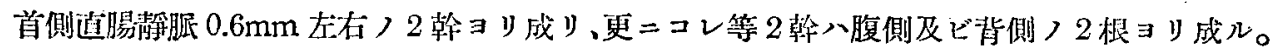

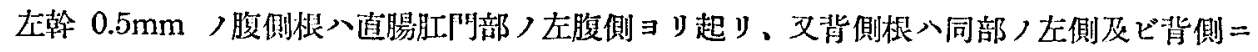

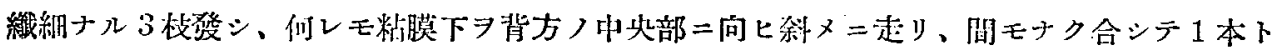

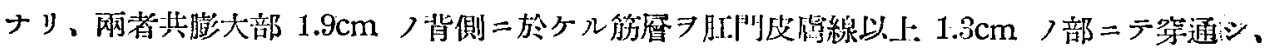
直チニ合流シテ 1 條ノ左幹トナリ、第通挠 $0.5 \mathrm{~cm}$ ニシテ右翰ト合一シテ首側直腸靜脈ノ本 翰卜成ル。

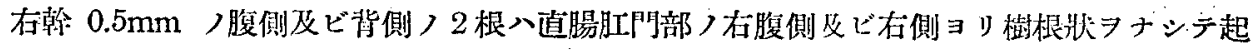

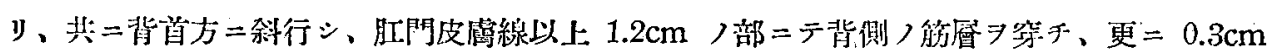

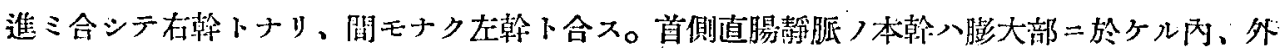

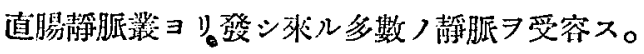

尾側運腸靜脈ハ去䓃共存セズ。

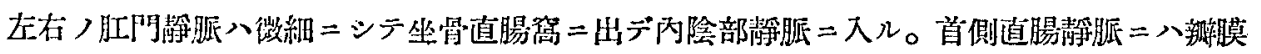

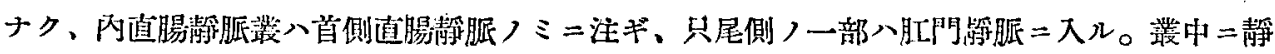
脈擴大

第23例 Rattus norvegicus 战 $\hat{0}$

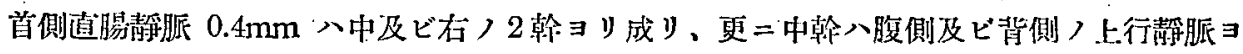
リ成ル。

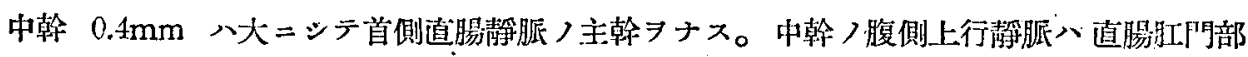

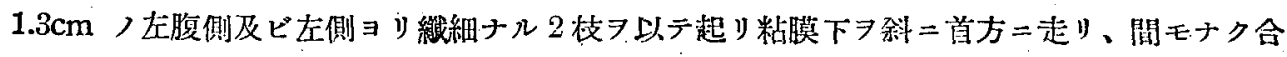
シテ 1 本トナリ、更二背側ノ中央部二進ミ肛門皮勴線以上 $0.6 \mathrm{~cm} /$ 部 $=$ 於テ後上行靜脈下 


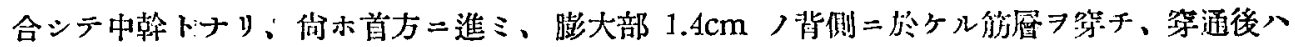

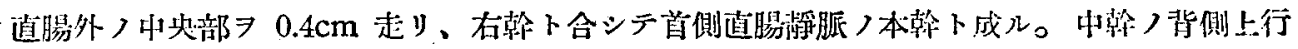

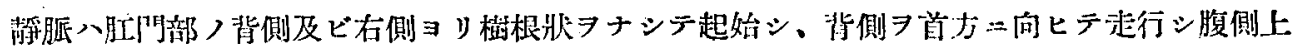
行塪脈二合ス。

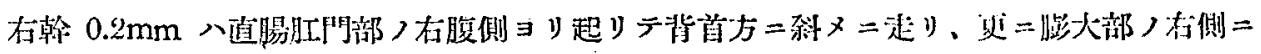

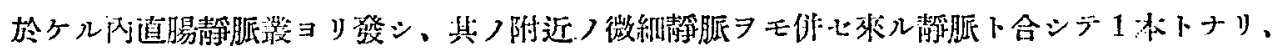

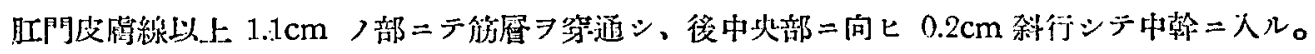

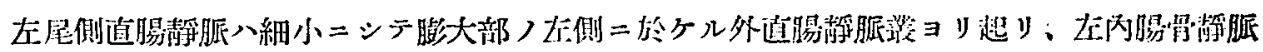
二入ル。

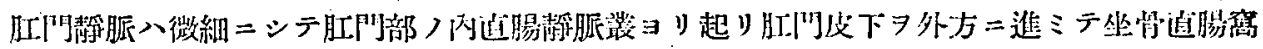

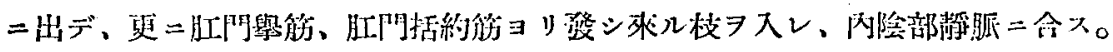

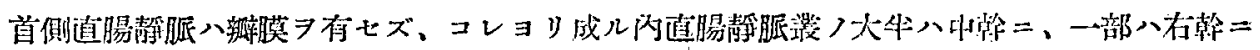

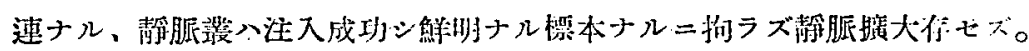

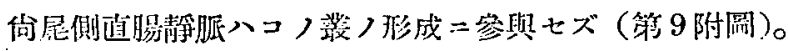

Insectivora 食潂涹

第 24 例 Erinaceus 蛸 $\hat{\sigma}$

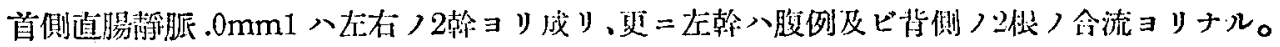

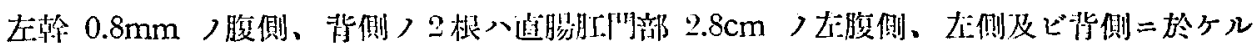

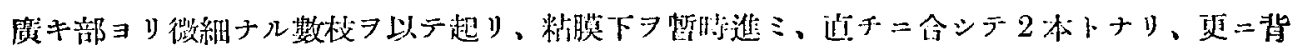

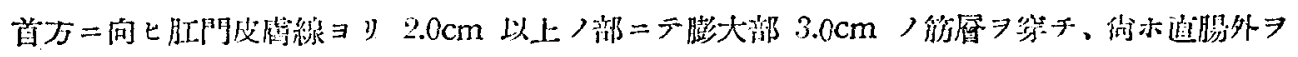

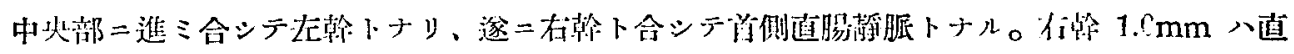

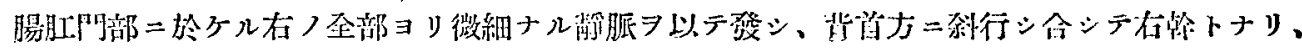

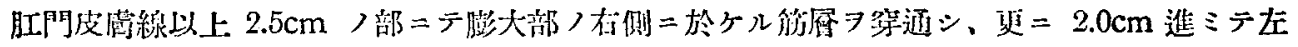
幹卜合流ス。

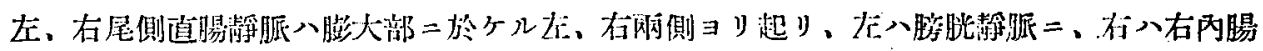
骨靜胍ニ注グ。

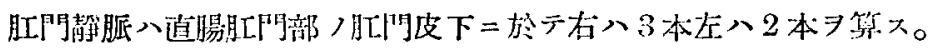

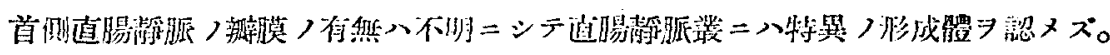

日、Carnivora 全肉颣

琶目。Pinnipedia 鰙脚数

第25例 Callotaria ursina 溫㑂敇

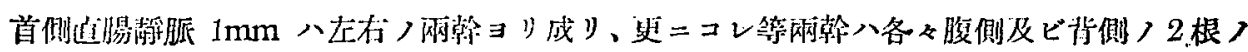


合流ヨリナル。

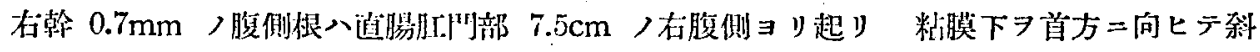

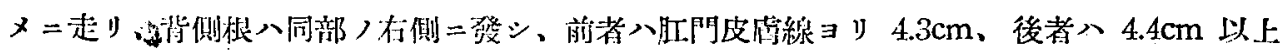

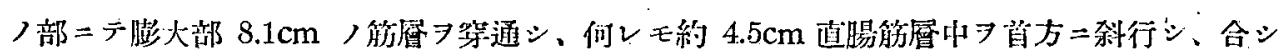

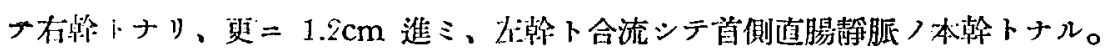

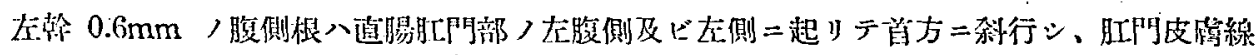

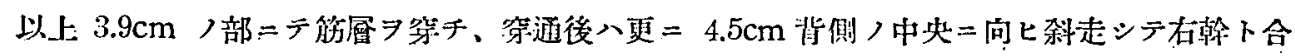

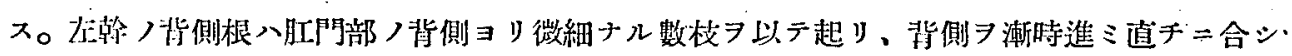

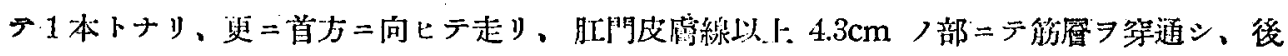
チ $3.2 \mathrm{~cm}$ 杀行シテ腹侧根卜合流ス。

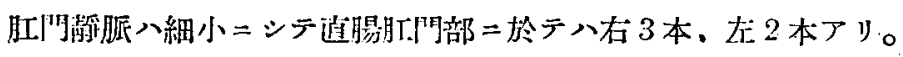

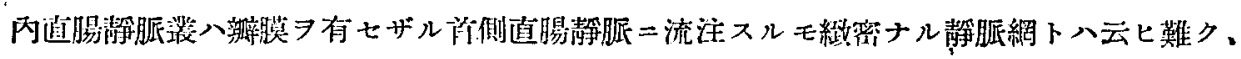
何等特貲つ形成體依七ズ。

第 26 例 Zalophus lobatus 酒驉 $\hat{\circ}$

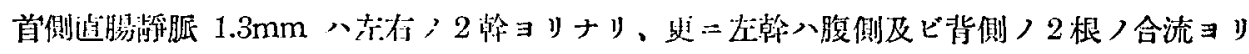
成ル。

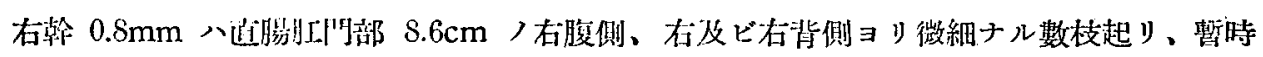

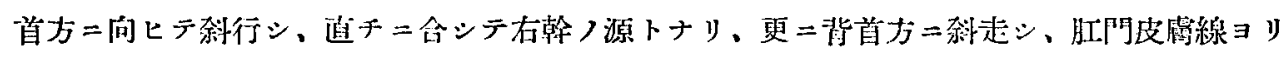

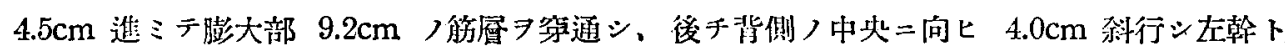

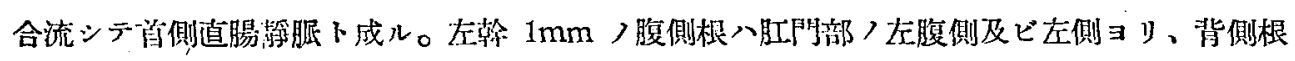

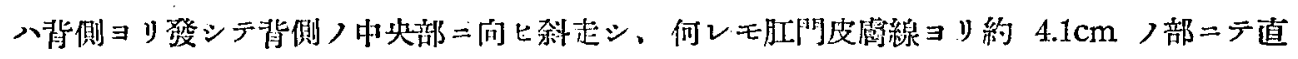

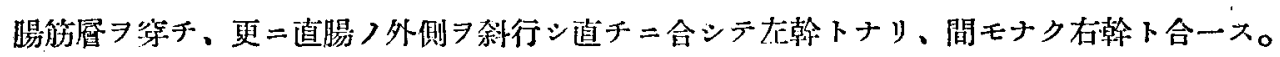

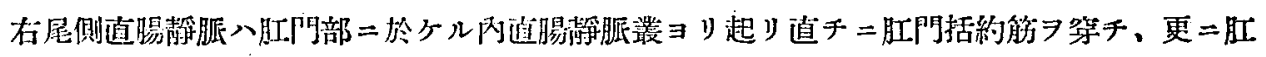

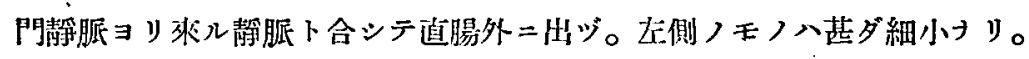

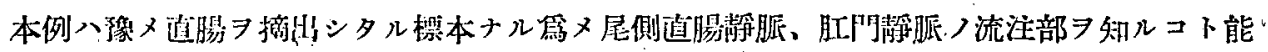
ハザリシモノナり。

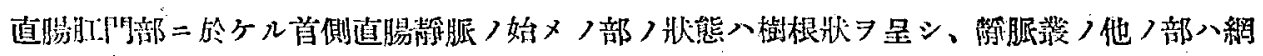
狀ヨ是スルノ他特記スペキモノラ見ズ。

\section{砬目、Fissipedia 肢脚類}

第 27 例 Canis familiaris $犬$ 合

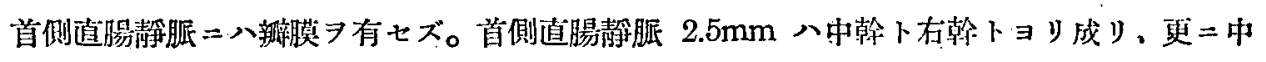
幹八左腹側、中及ビ背侧/上行静脈/合流ヨリ成孔。 


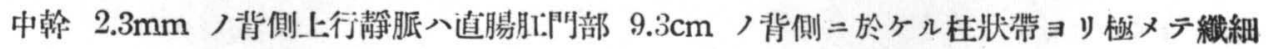

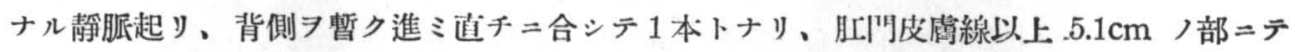
中及ビ背側ノ兩上行靜脈ト合流シデ尚側直腸靜脈ノ中翰トナリ、更 $=0.5 \mathrm{~cm}$ 進ミテ膨大部

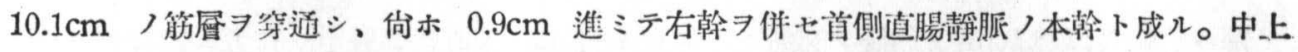
行靜胍八肚門部ノ右背側ヨリ始マリ、背首方二向ヒテ斜行シ、背侧上行靜脈ノ外側 $尹$ 横ギ リ、肚門部ノ左側区ビ左背側ヨリ發シ來ル靜脈ト合シ、直チ二背側上行靜脈卜合流ス。布腹 側上行靜脈八肛門部 / 左腹側ヨリ數枝起リ、暫時刹走シテ合シタル直後 2 本ノ靜脈二歧レ、 更二背首方二科メ二進ミ、遂ニ合シテ 1 本ト成リ、通チニ背側上行靜脈二合ス。

右翰 $1 \mathrm{~mm}$ 入道腸䏖門部ノ存腹側及ビ右側ニ於ケル柱狀帶ョリ3枝起リ、首方ニ走リ間モ

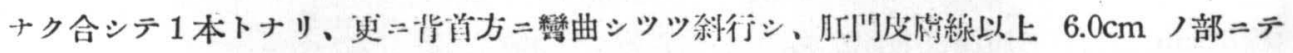

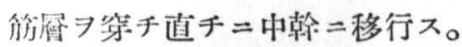

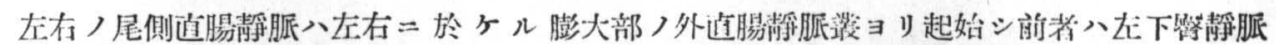
二、後者八队腸少清胍 $=$ 入ル。

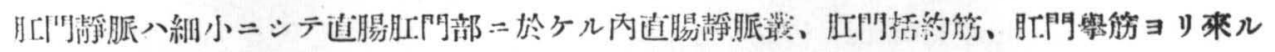

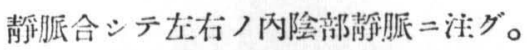

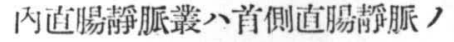
主翰ヨリ殆ンド形成セラレ、ソノ

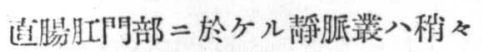

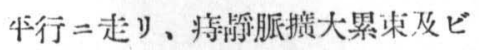

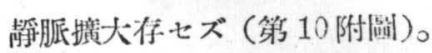

第 28 例 犬 ㅇ

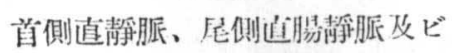
肍門靜脈〉三系ニヨリ形成七儿内

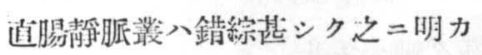
ナル靜脈援大 7 認么(第 10 四到)。

其)他犬 19 檢體中內直墕捊脈 罣二靜脈撗大 92 例二於テ認メ夕 リ。

第 29 例 Vulpes juponicus 狐宁

首側直腸靜胍 $1.0 \mathrm{~mm}$ 八龙右 2 翰ョリ成リ、左幹八腹側及ビ背
第 10 阅犬 $犬-\frac{2}{3}$

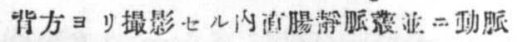

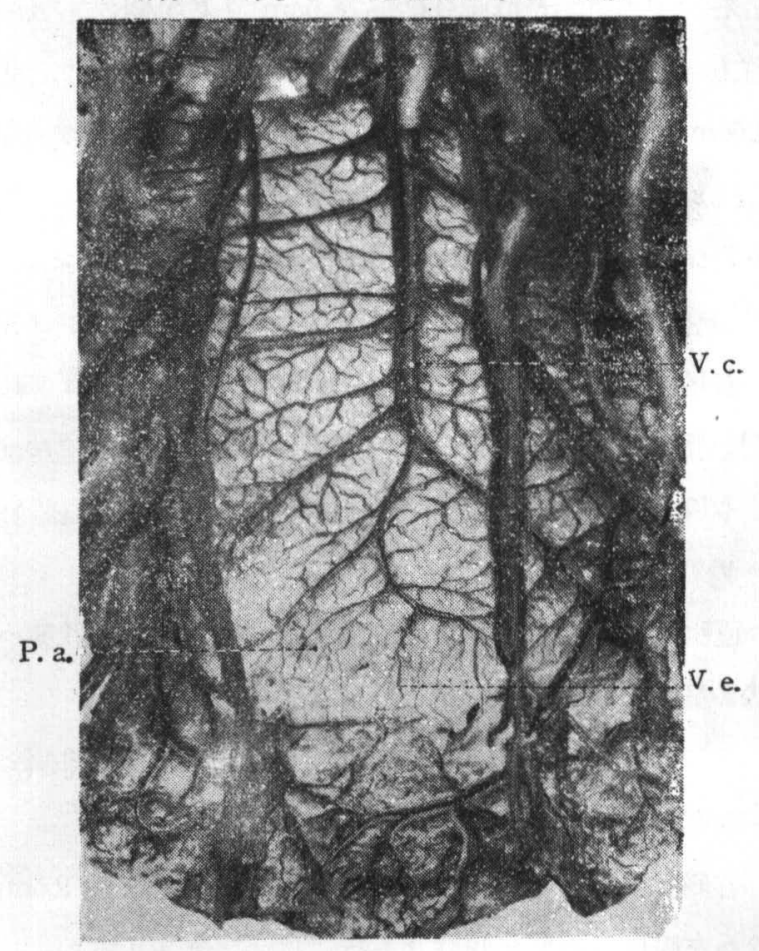


側ノ 2 根ヨコ成ル。

右幹 $0.6 \mathrm{~mm}$ 八更二腹側及ビ背側ノ.上行静脈ヨリナル。コレ等上行靜脈八正腸肍門部 $5.4 \mathrm{~cm}$ ノ右腹側ヨリ右背侧二涉ル部ョリ微細 ナル數枝起リ、共二粘膜下

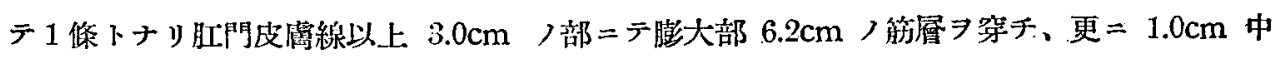

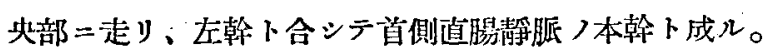

左幹 $0.7 \mathrm{~mm}$ 八腹側根八臬腸肛門部二於ヶル左腹側ヨリ、背側根八左側及ビ背側二發シ。 何レモ首方二向ヒテ進ミ、前者入肛阴皮膚線以上 $2.1 \mathrm{~cm}$ 、後者八 $2.3 \mathrm{~cm}$ ノ部ニテ筋膡 通シ、約 $1.1 \mathrm{~cm}$ 中央部二岽行シ、合シテ左幹トナリ、直チ二右幹ト合流ス。

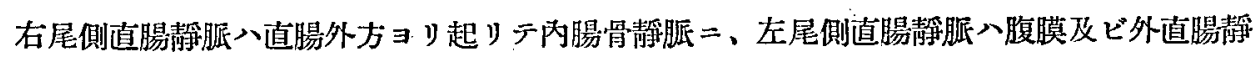

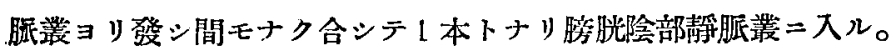

肛門靜脈八右 $=3$ 本、左 $=2$ 本习有久。

首側直腸靜脈系 $=$ 八瓣膜 ク特記ヘべキモノタ見ズ。

第30例 Nyctereutes viverrinus 狸 $\hat{s}$

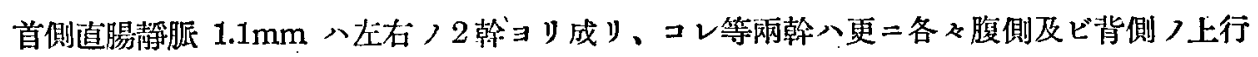
靜脈ヨリナル。

右幹 $0.7 \mathrm{~mm}$ /腹側上行静脈八直腸肛門部 $5.9 \mathrm{~cm}$ /右腹側及ど右側ヨリ起リ、背首方二㫺斗 行シ、肛門皮虚線以上 $4.0 \mathrm{~cm}$ /部ニテ背側上行靜胍下合シ、佾ホ $0.4 \mathrm{~cm}$ 走リテ膨大部 $6.5 \mathrm{~cm}$

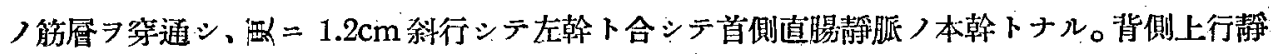
脈八直腸肛門部 $=$ 於ヶル右側及ビ右背側 $コ$ 發シ、粘膜下ヨ稍々斜メ二走リ、腹側上行靜脈 卜合流ス。

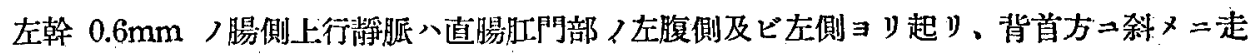
リ、直腸肛門部う背側ヨリ起リ來レル背側上行靜脈並二內直腸靜胍業ヨリ發スル微細ナル靜

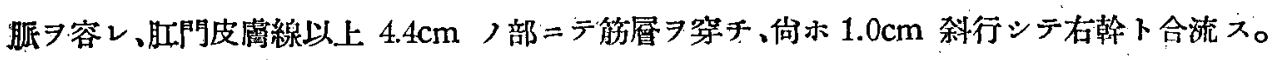
尾側直腸靜脈ト名ヅクルニ足儿程ノ靜脈ヨ見ズ。

肛門静脈八左右各《 3 本

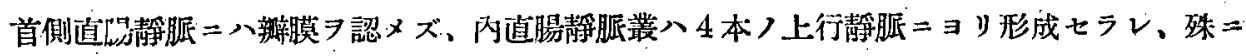

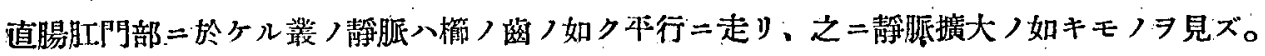

第 31 例 Mustela erminea nippon 鼣鼠. $\hat{\text { o }}$

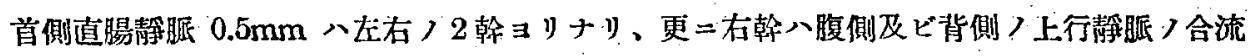
ヨリ成ル。

右幹 $0.4 \mathrm{~mm}$ 腹側上行靜脈八直腸肛門部 $1.1 \mathrm{~cm}$ /右腹側及ビ右側 $コ$ リ起リ、肛門皮滈線 


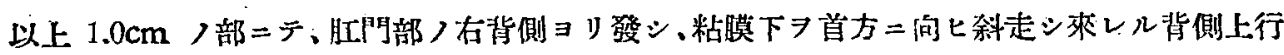

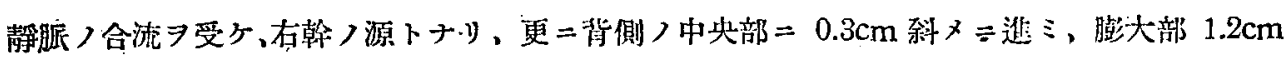

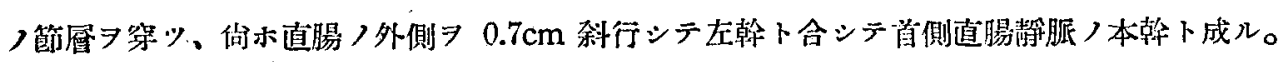

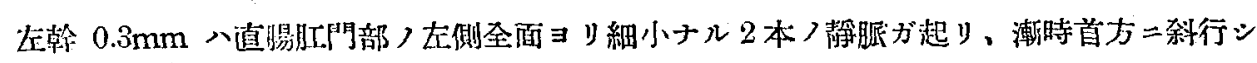

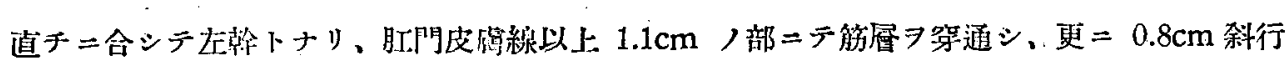
シテ存䇐卜合ス。

肚門靜脈八大在各 3 本习算ス。

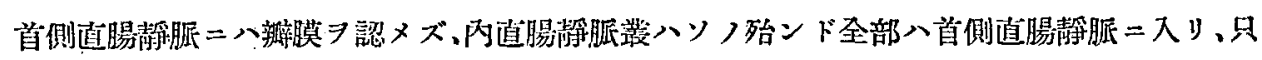

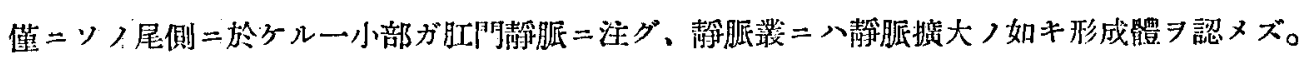
第 32 例 Lutra 水獭 $\delta$

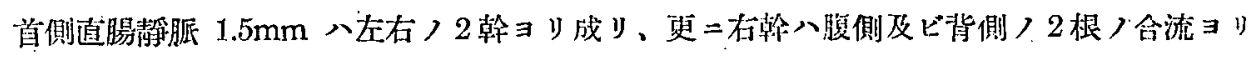
成ル。

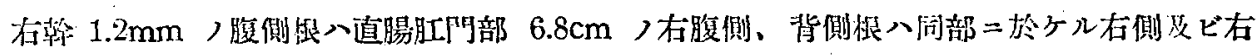

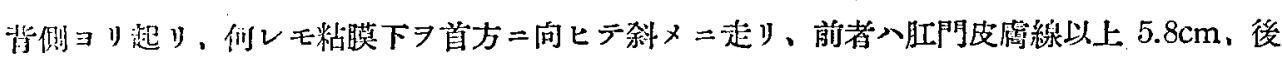

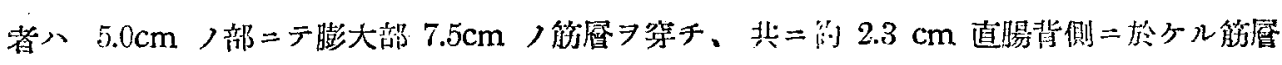

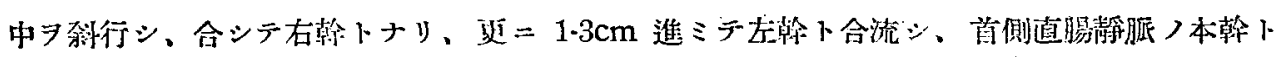
成儿。

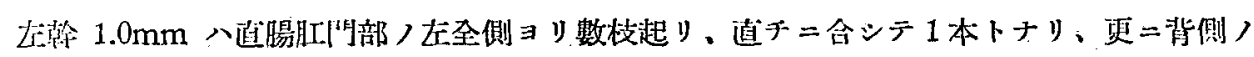

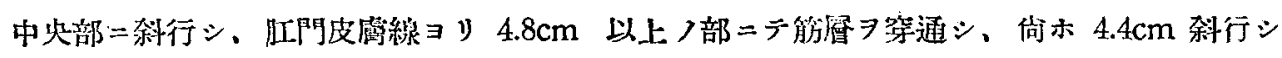
テ右翰下合ス。

尾側遖腸靜脈八䒫ダ細小ナリ。

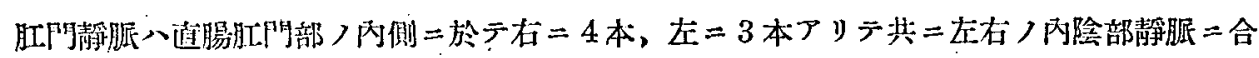
ス。

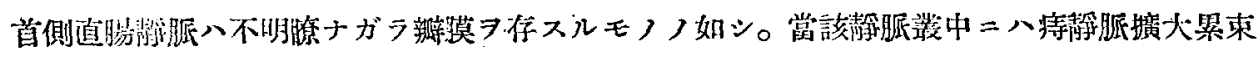
ノ如キ形成體シ認メズ。

第 33 例 Meles taxus 爑 $q$

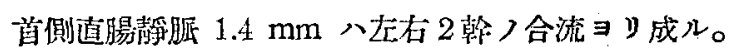

右翰 $1.0 \mathrm{~mm}$ 八遖腸肍門部 $7.2 \mathrm{~cm}$ ，存側全面 $コ$ 微細ナル數枝起リ：粘膜下习首方二向

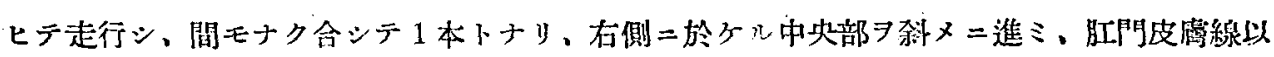

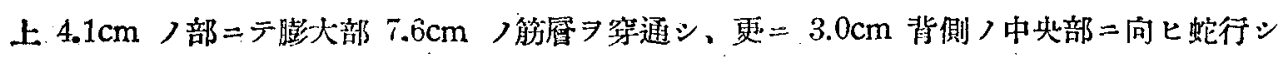
左翰下合流シテ首侧道腸静脈ノ本翰トナル。

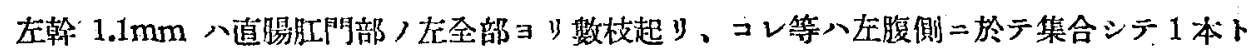


ナリ首方二科行シ。肛門皮成線ヨリ $4.3 \mathrm{~cm}$ 以上ノ部ニテ直腸能層

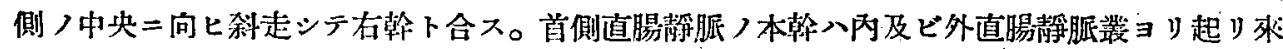
レル數本ノ靜脈 $フ$ 容ル。

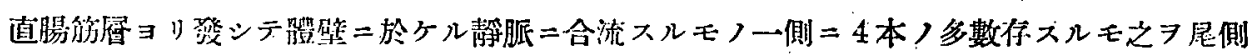

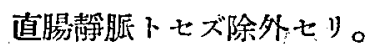

肞阴靜脈八左 $=1$ 本、有 $=3$ 本

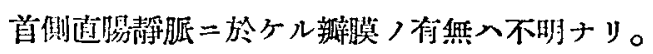

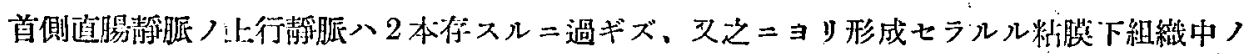

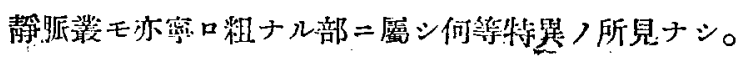

第 34例 Felis domestica 猫

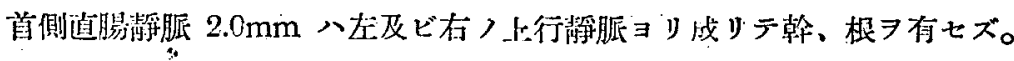

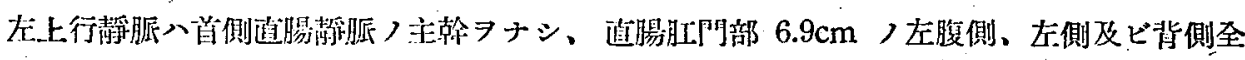

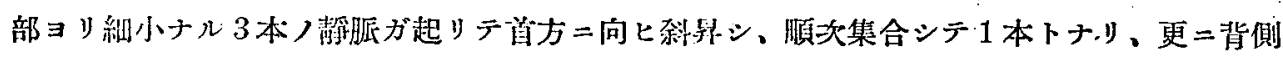

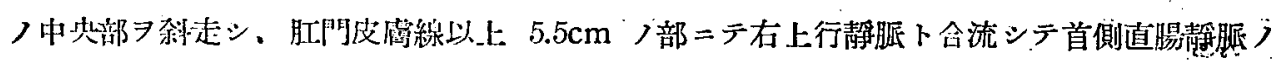

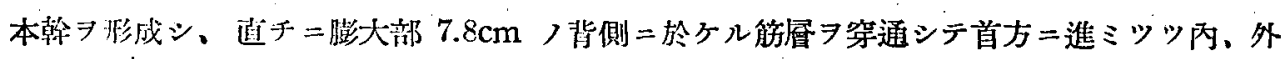

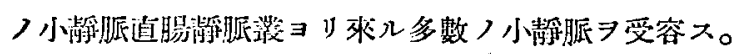

在上行静脈八遖腸肍門部ノ右腹側及ビ左側ヨリ 3 本ノ微細ナル静脈發シ、首方二斜行シ。

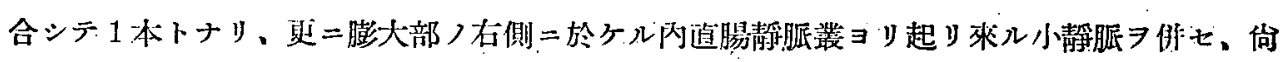

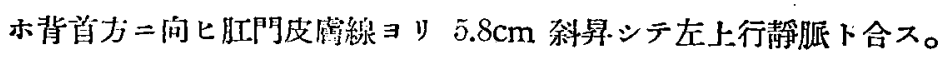

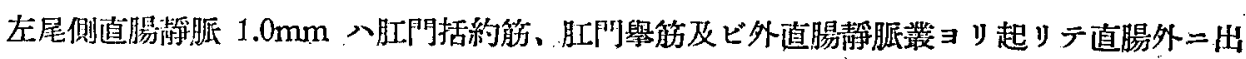

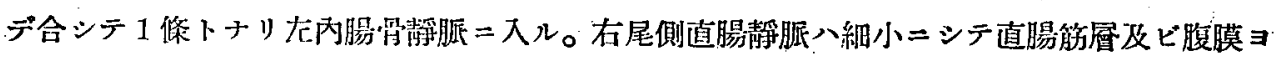
起り右內腸舴靜脈二合ス。

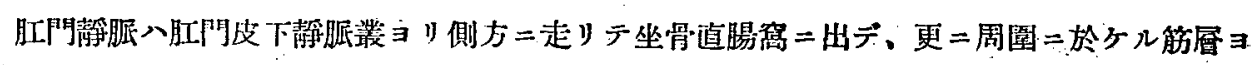
リ來儿滛脈ト合シテ內陰部靜脈ト合ス。

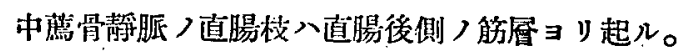

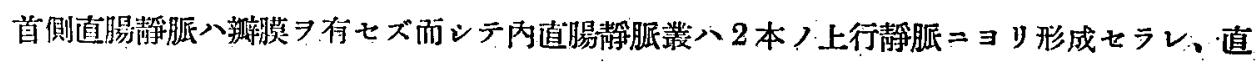

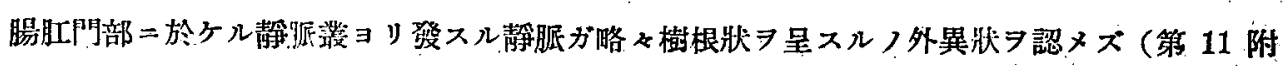
圖)。

\section{第 35 例 猫}

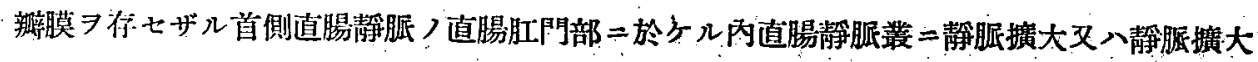
樣〉形成體 7 胃几(第11 圖)。

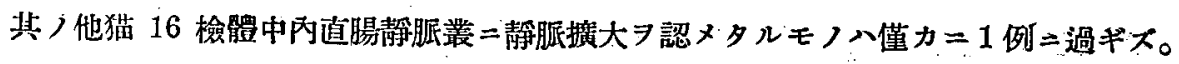


第 11 圆 猫 $\odot \frac{2}{3}$

背方ョリ撮影セル內直晹靜脈灇亚二動脈

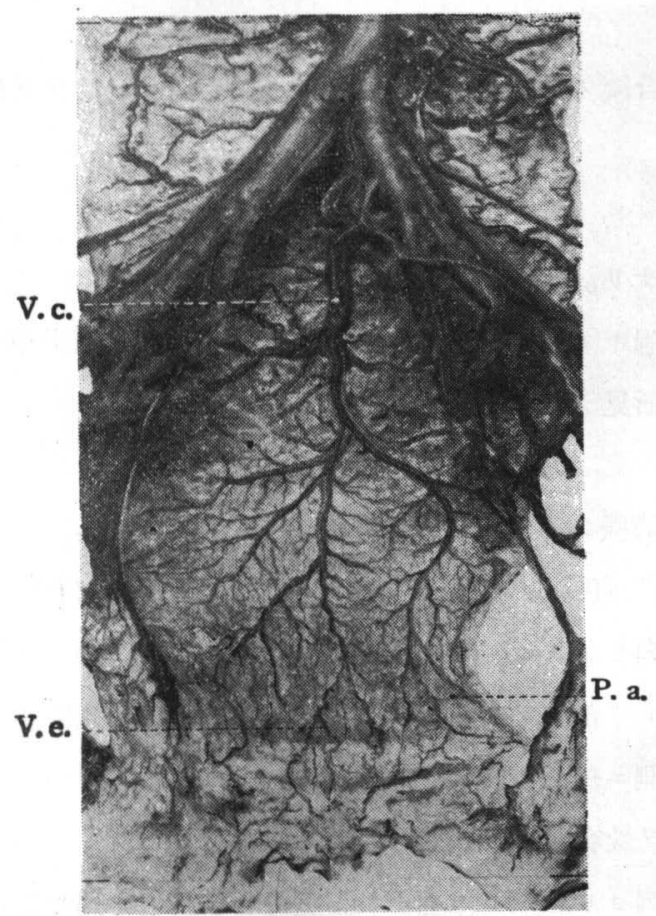

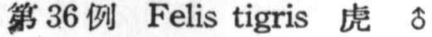

首侧直腸靜脈 $4.0 \mathrm{~mm}$ 八左右ノ 2 幹 $\exists$ 成ル。

右幹 $3.0 \mathrm{~mm}$ 八更二腹側、中、背側 ノ上行靜腿 $ョ$ リル。腹側上行靜脈 八直腸肚門部 $16.0 \mathrm{~cm}$ ノ右腹側及ビ右 側並二肚門靜脈卜槛く大ナル連合 ス 3 本ノ細小ナル靜脈トシテ起リテ粘 膜下 7 首方二向ヒ蛇行壯 $=$ 科 $=$ 走リ。 逐ニ合シテ 1 本トナリ、肛門皮膚線以 上 $12.4 \mathrm{~cm}$ ノ部ニテ背侧上行靜脈卜合 流シテ右幹トナリ直チニ膨大部 17.7 $\mathrm{cm}$ ノ背側ニ於ヶル箊層 7 穿通ス。穿 通後八更 $=4.7 \mathrm{~cm}$ 背侧 中央部 7 科 行シテ左幹ト合シテ首側直腸靜脈ノ本 幹ト成ル。右幹, 中及ビ背側上行靜脈 八直腸肛門部ノ右側及ビ右背側ョリ起 リテ背首方ニ向ヒテ走行シ、肚門皮膚線以上 $11.8 \mathrm{~cm}$ ノ部ニテ合シテ 1 本トナリ、直チニ腹 側上行靜脈下合シテ笳層习穿ツ。

左幹 $2.5 \mathrm{~mm}$ 八直腸肛門部ノ左側及ビ左腹側ヨリ 3 本ノ微細ナル靜脈起リテ首方二科走シ。

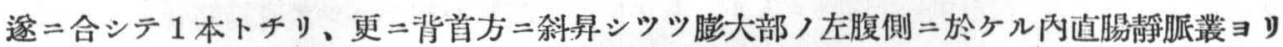

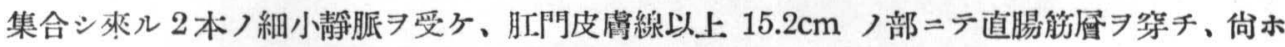
$2.0 \mathrm{~cm}$ 斜メ 二進ミテ右翰ト合ス。左右ノ尾側直腸静脈入外直腸靜脈丵ヨリ起リテ內腸骨靜 脈二入ル。

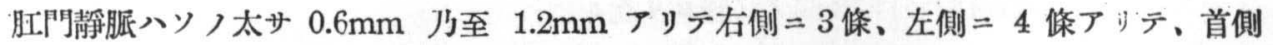

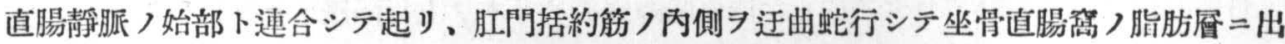
デ此所ニ於テ內直腸靜脈叢ヨリ起リ肚門括約筋 部靜脈 $=$ 注グ。

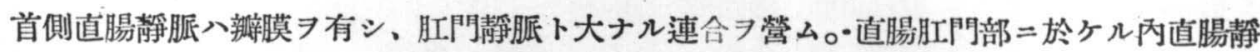
脈叢つ微細ナル靜脈八稍ね直線狀ニ走リテ房狀 呈シ、他部ニ於ケル不正ナル網狀ト八聊カ 其形狀

第 37 例 Felis pardus 豹 $\hat{0}$ 


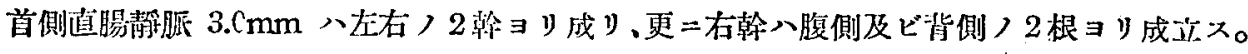

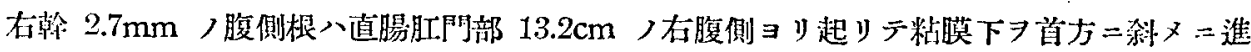

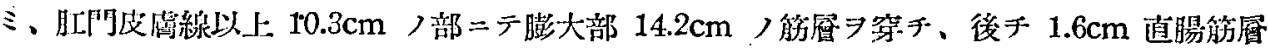
中ヨ刹走シテ背側根ト合シテ右翰トナリ、更二背方ノ中央部 $=2.5 \mathrm{~cm}$ 進ミ、右幹卜合流シ

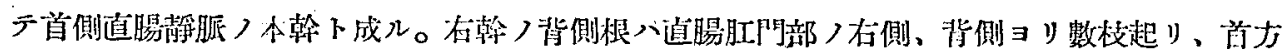

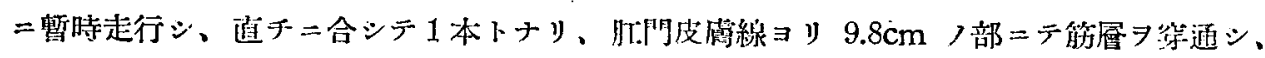
倘ホ $1.0 \mathrm{~cm}$ 科行シテ腹側根ト合ス。

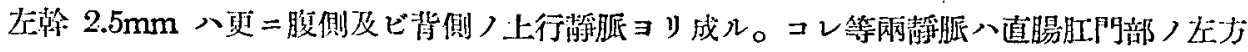

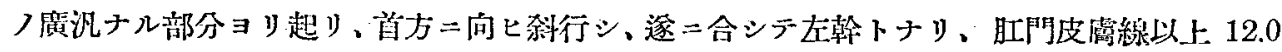

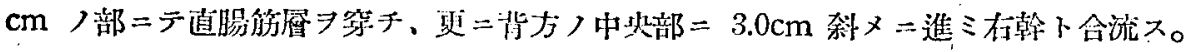

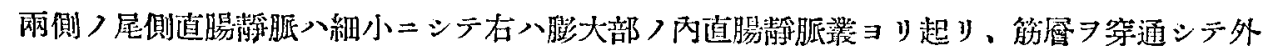

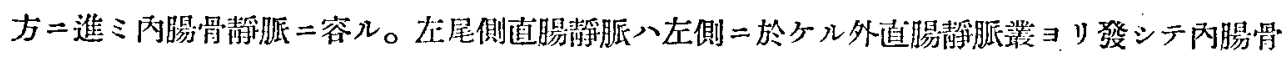

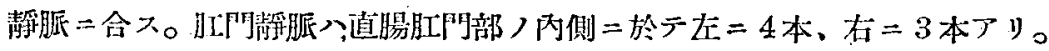

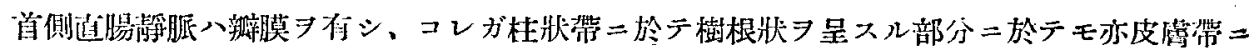

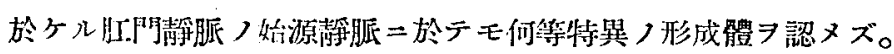

第 38 例 Ursus japonicus 熊

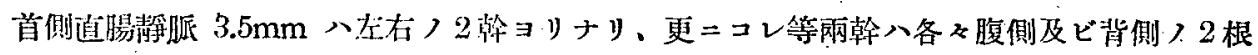
ノ合流ェリ成几。

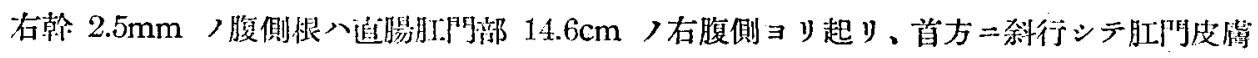

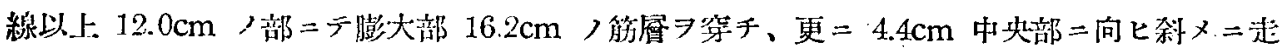

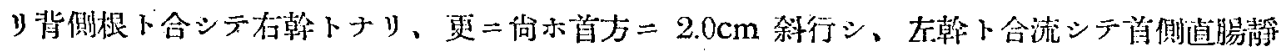

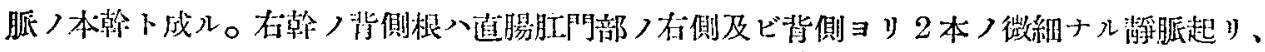

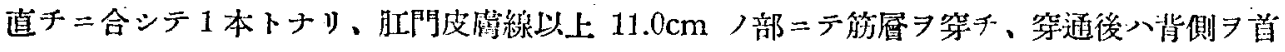
方 $=3.6 \mathrm{~cm}$ 進ミ腹側根卜合ス。

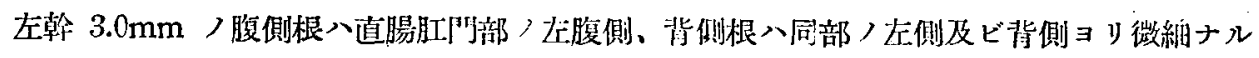

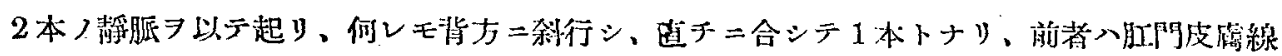
以上 $8.8 \mathrm{~cm}$ 、後者入 $9.4 \mathrm{~cm}$ /部二テ直腸筋層习第通シ、後千兩者八約 $3.6 \mathrm{~cm}$ 背首方二科行 シ合シデ左翰トナリ、更 $=5.4 \mathrm{~cm}$ 中央部二向比斜メ二進ミ右翰卜合流ス。

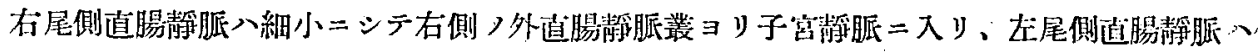

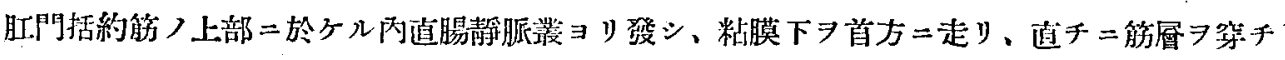
テ直腸外二出デ、队腸骨靜脈二容ル。

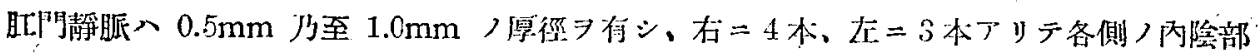


靜脈二スル。

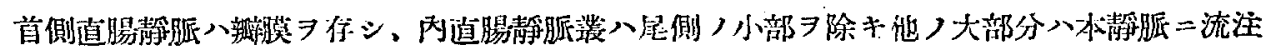

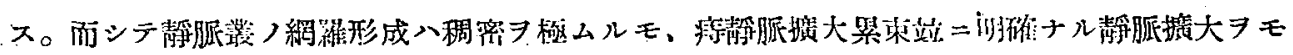
認メズ。

\section{Primates 㢣長頪}

\section{Simiae 猿猴頪}

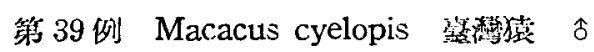

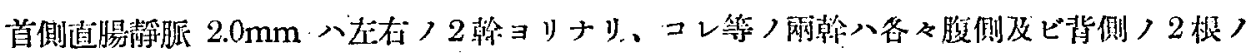
合憱ョリ成ル。

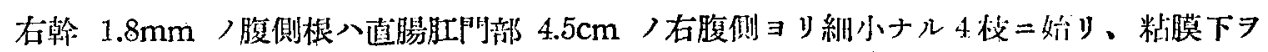

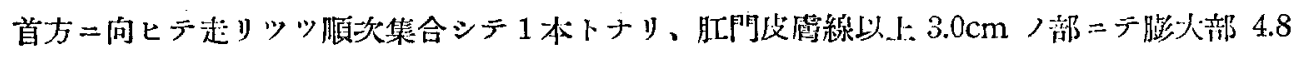

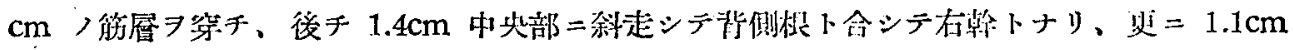

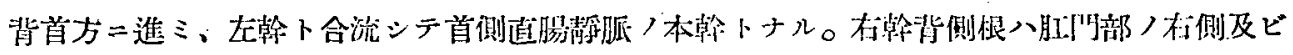

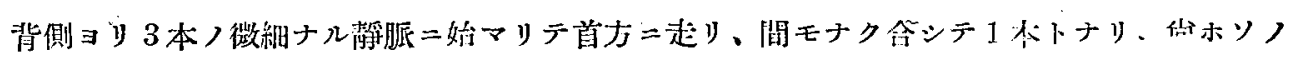

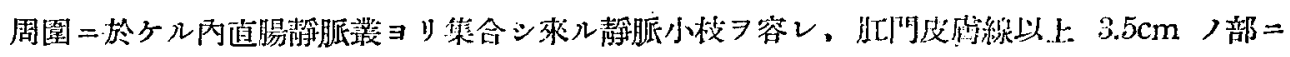

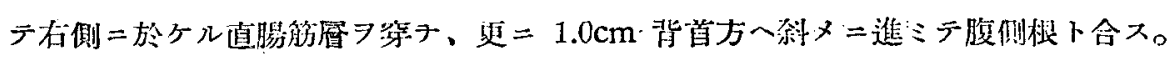

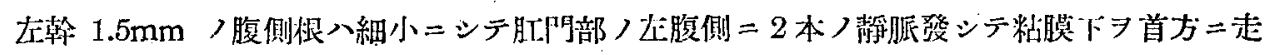

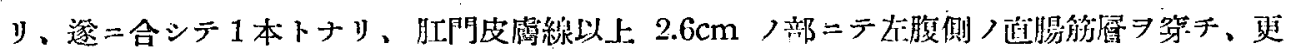
$=1.5 \mathrm{~cm}$ 斜行シテ背側根ト合シテ左㣀トナリ、少ホ $1.1 \mathrm{~cm}$ ソノ中夯部二進ミテ在翰卜合流ス。

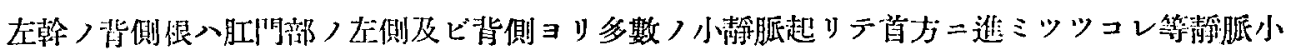

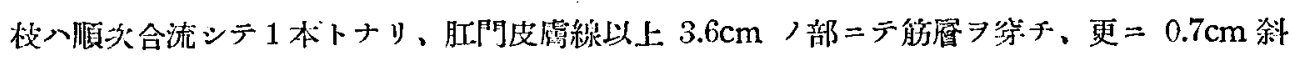
行シテ左翰腹側根下合大。

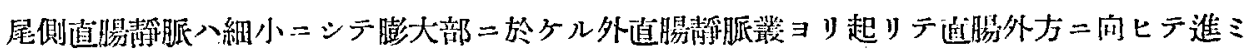

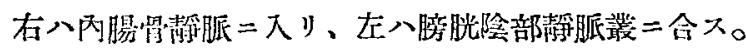

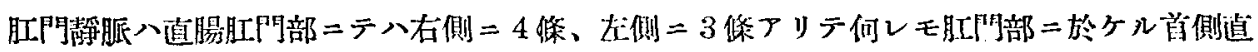

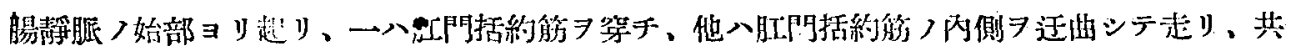

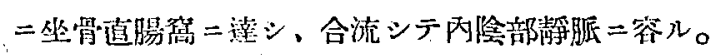

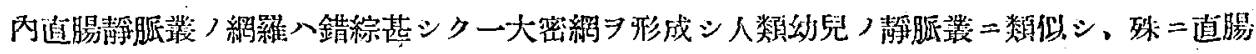

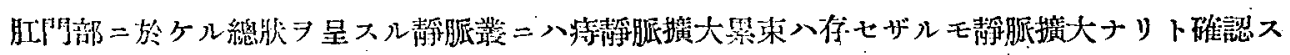
ベキモノ2佃保在スルラ見ル。

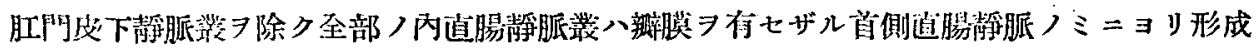
七うル(第 13 附螣)。 
第 12 圆 手長猿 $\circ \frac{1}{1}$

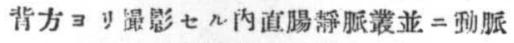

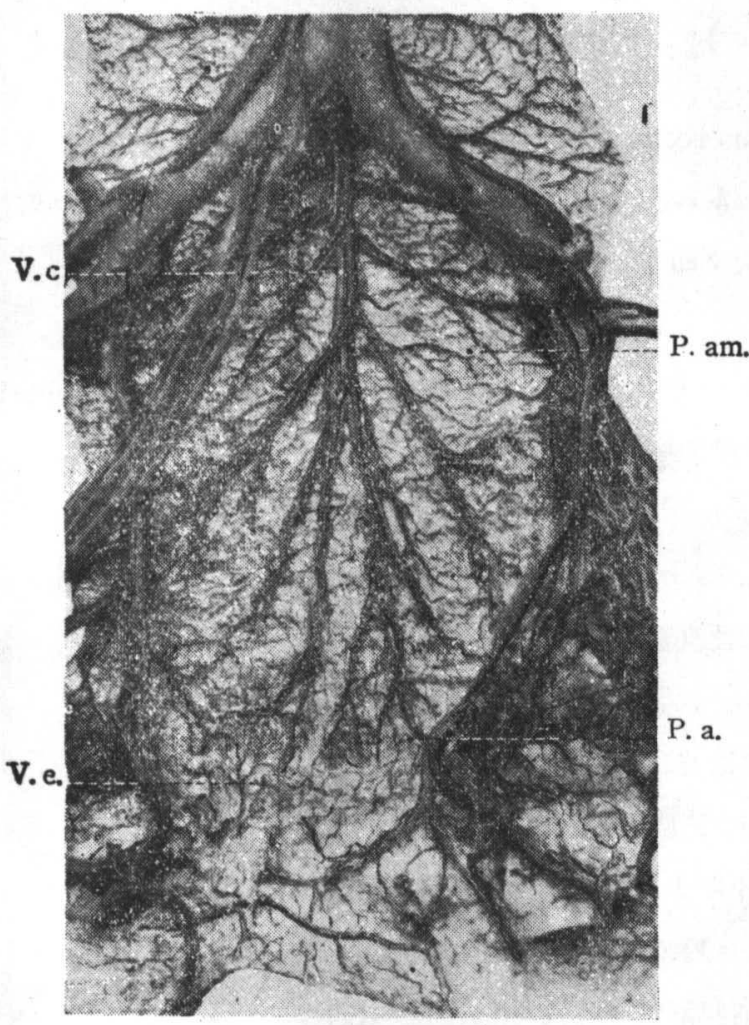

第 40 例 Macacus fuscatus

日本猿 $\delta$

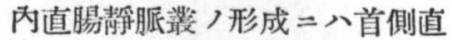
腸偁脈、肘門静脈 $>$ 他 $=$ 膨大部 $=$ 於ケル靜脈丵ノ一部傋成二八尾側 直腸靜脈ガ参與ス、而シテソノ直 腸肛門部ノ静脈丵ノ形狀八他部ノ 網狀卜ハ異リ柳枝狀 $コ$ 呈シ、本例 ニ於テ八靜脈擴大及ビ䁘脈拱大樣 ノモノ八存在セズ。

第 41 例 Hylobates 手長猿 千 首側直腸塪脈 $2 \mathrm{~mm}$ 八左、右及 ビ中ノ 3 幹ョリ成リ、更二中幹八 中及ビ左、右ノ上行靜脈ノ合流ヨ リナル。

中幹 $1.8 \mathrm{~mm}$ 八本靜脈〉主幹 ナスモノニシテ之ヨナス 3 本ノ上 行靜脈八直腸肛門部 $5.3 \mathrm{~cm}$ ) 背 側ノ全面及ビ左、右ノ兩側ョリ起 リテ粘膜下フ首方ニ向ヒテ科走シ肛門皮膚線以上 $4.9 \mathrm{~cm}$ /部ニテ合シテれ幹トナリ、直チ 二膨大部 $5.9 \mathrm{~cm}$ ノ背側ノ中央部ニ於ヶル筋層 兩幹ノ合流ヨ受ケテ首側直腸靜脈トナル。右翰 $1.1 \mathrm{~mm}$ 八直腸肛門部ノ右腹側 $=$ 光シ、首背 方二科走シテ肚門皮膚線以上 $4.6 \mathrm{~cm}$ ) 部ニテ直腸筋層 科メ =進ミ中幹二注グ、龙幹八肛門部ノ左腹側 $コ$ 微細ナル 2 本ノ小枝二始マリ、暫時科行 シ合シテ 1 本トナリ、向ホ背首方二走リ肛門皮虞線ヨリ $4.4 \mathrm{~cm}$ 以上ノ部ニテ筋層ヨ穿通シ。 更二直腸外側

左尾側直腸靜脈 $0.7 \mathrm{~mm}$ 八膨大部ノ左側ニ於ヶル外直腸靜脈叢 $リ$ 起リ首外方ニ斜行シテ 左內腸骨靜脈二注グ。右尾側直腸靜脈八直腸筋層ヨリ起リ閉䥊靜脈二入ル。

肛門靜脈八細小ニシテ左右各 3 本フリ、ソノ各 1 本ハ淺外尾靜脈二合シ、他ノ 2 本八內㓌 部靜脈二入ル。

首側直腸静脈 ニ八瓣膜

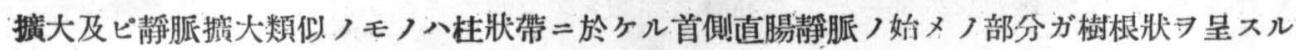


個所二存シ、其形狀入細長ナル紡錘狀ヨ呈スルモノ多シ(第 12 圖)。

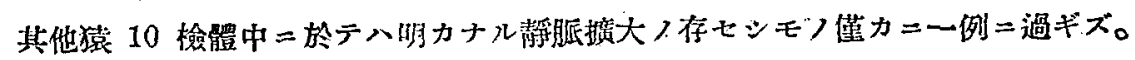

\section{4. 總 括 所 見}

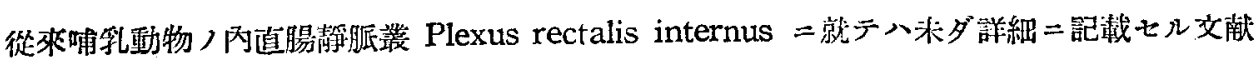

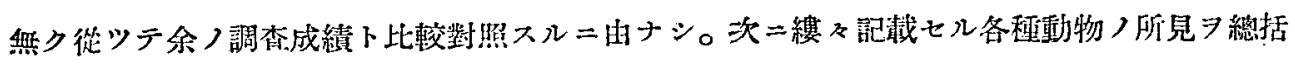
シ其ノ中須要ナル項目习列擧スレバ次ノ如シ。

第 1. 哺乳動物 $>$ 遖腸形妝

哺乳動物 つ直腸肛門部 Pars analis recti =於ケル幅徑ハ一般二膨大部 Pars ampullaris

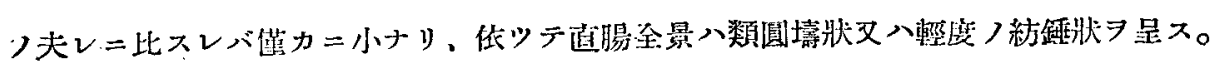

第 2. 直腸清脈入辫膜装䁂

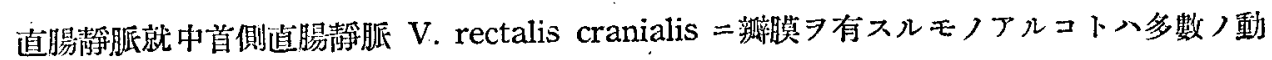
物二對シ、静脈注入入途次余八始メテ之フ發見ス。

郎千靜脈辦索

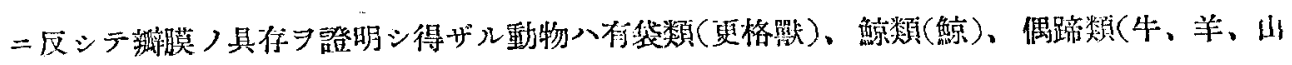

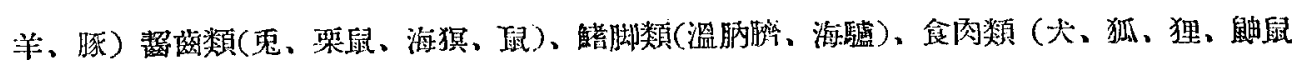

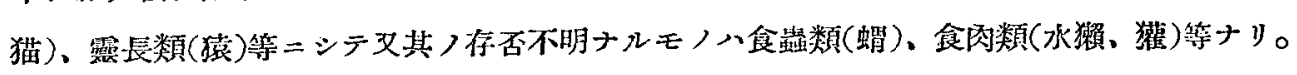

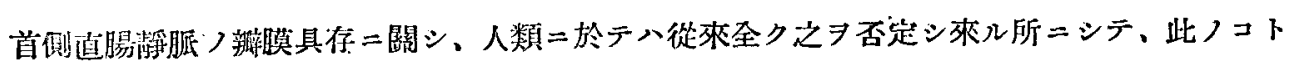

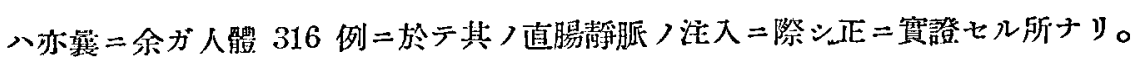

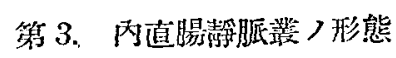

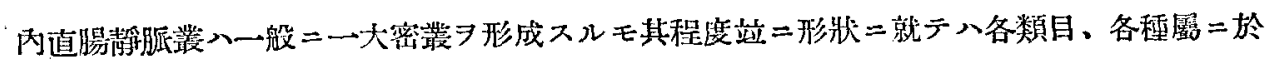
デ各く多少つ特長ヨ有ス。然レ共次ノ2 點八各種動物ヨ通ジテ殆ンド共通ス、郎チ膨大部二

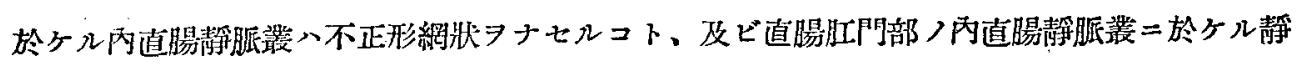

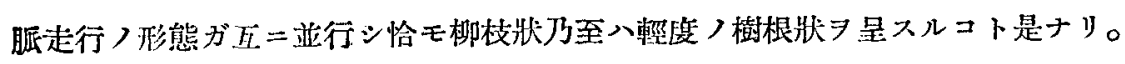

第 4. 直腸 諸篟脈

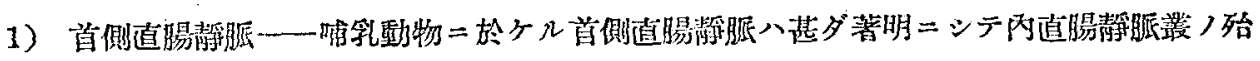

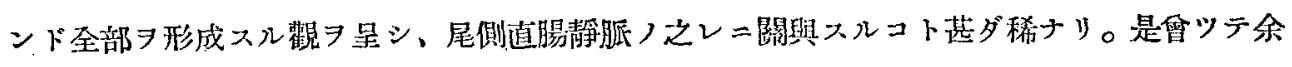
ガ人類二於ケル直腸靜脈ノ檢索二於デ實驗セル結果卜甚ダ異ナル所ニシテ、人類二於ヶル內

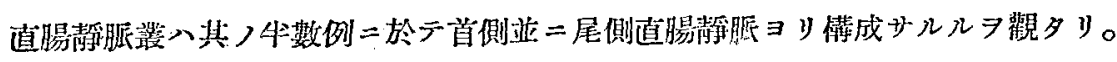

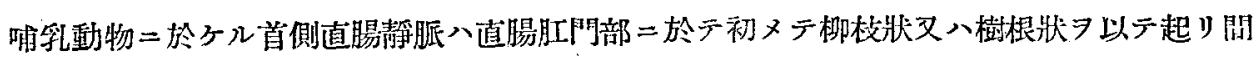
モナク合シテ約 5 條 (2 万至 8 條) 队上行静脈 V. ascendens トナリ、粘膜下フ首背方二向

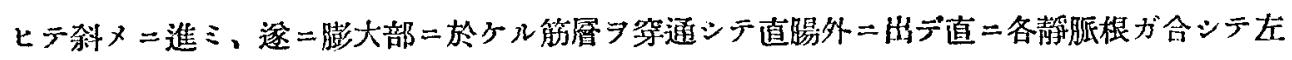




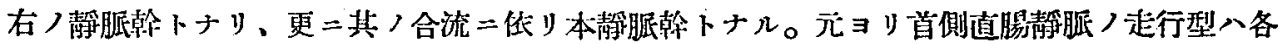

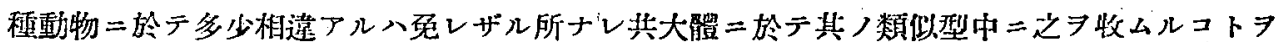

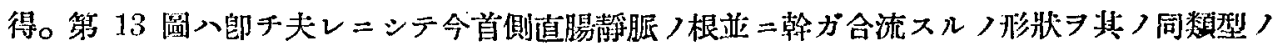
多數ナルモノョリ順次二列翼スレバ左ノ型二區别スルコトヨ得。

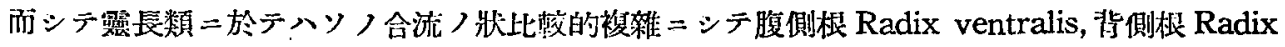
dorsalis ガ合シテ夫ょ左翰 Truncus sinister 及ビ右幹 Truncus dexter トナリ、更二方 右兩㲦ガ合シデ首側直腸靜脈ノ本翰トナル、第 2 型ノ如シ。

第 13 阅

1

2

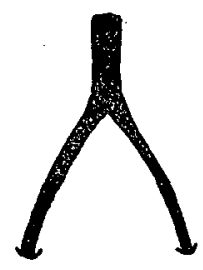

6

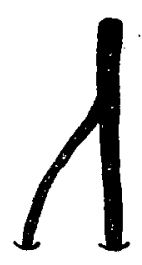

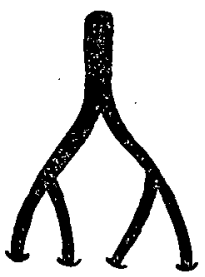

7

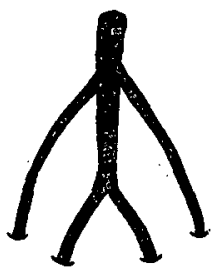

3

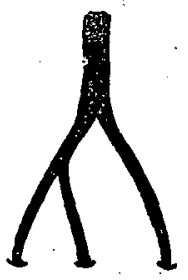

8

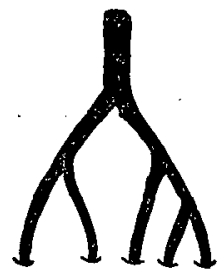

4

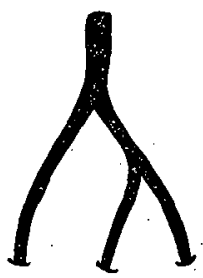

9

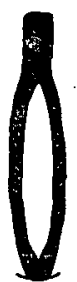

5

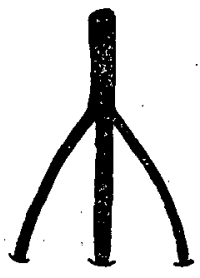

10

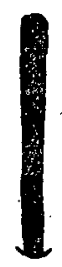

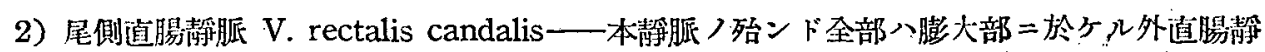

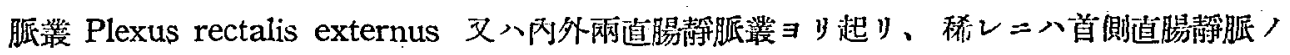
起源卜其ノ邨

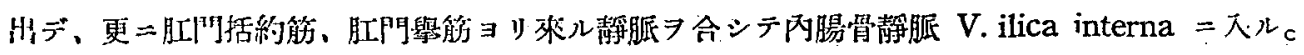

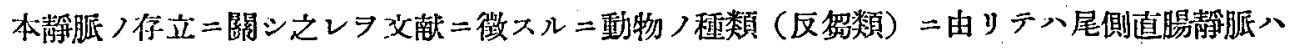

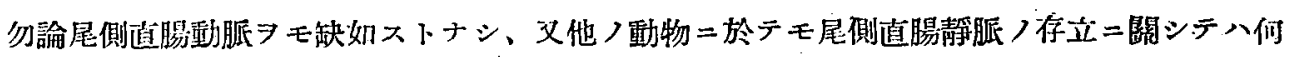
等ノ記載ナキモノアリテ等闑視セラルルノ蝛ミアリ。然レ共本靜脈八人類二於テハ解剖學上. 乃至八臨郴上枈ダ重要ニシテ且興味深キ靜眽ナリト思考シタルニ依リ特二唓乳動物二於ケル

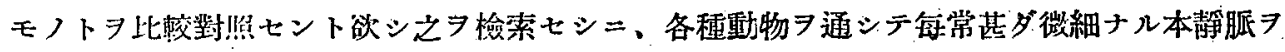
有シ何レモ體壁及ビ泌尿生殖器つ静脈二流注ス。其つ保数つ如キモ 1 側 2 乃至 4 本フ見ルコ

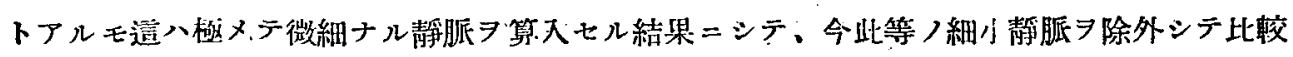


的大ナル本靜脈ノミヨ索メントセバ皆無或ハ不定ナリト謂フベシ。

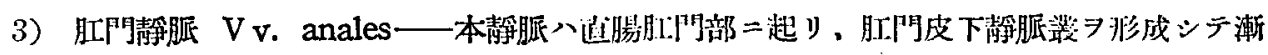

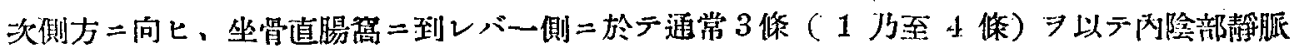

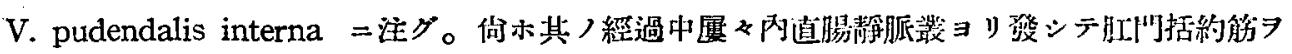

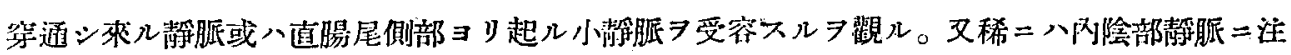
ガズ直二淺外尾静脈 V. caudalis lateralis superficialis 或八邑側然静脈 V. glutea caudalis 二入ルモノアリ。

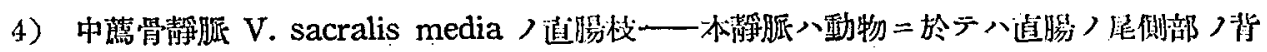

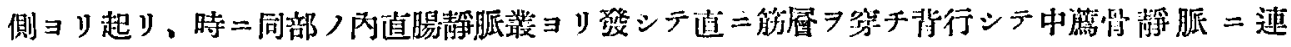

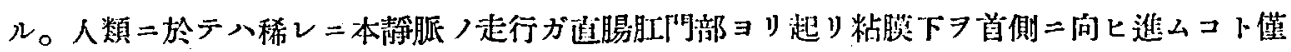

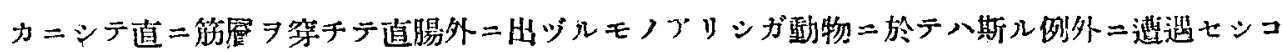
トナシ。

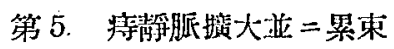

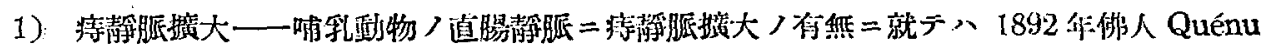
ガ人類二於ヶル直腸靜脈二閣入儿諭文 E'tude sur les veines du rectum et de l'anus 中 $=$ Or voici un lapin dont les veines mésaraïques inferieures ont été magnifiquement injectées en bleu, par mon ami M. Lamothe; des radicules veineuses rectales émanent d'un plexus souscutané, à l'union de la peau et du rectum; nulle part trace d'ampoules. Nous n'avons pas été plus heureux en étudiant le rectum du cheval et celui du chien.

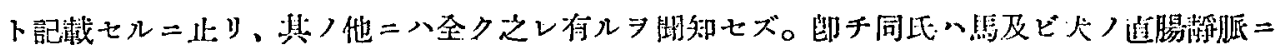

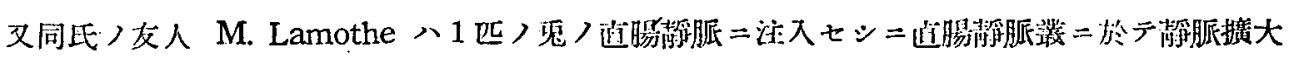

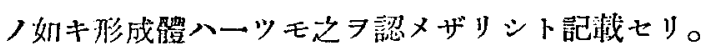

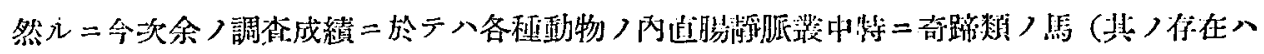
22 例中 3 例)、偶蹄類 ᄀ年 (28 例中 8 例)、跃(18 侧中 6 例)、食肉類ノ犬( 21 例中 3 例)、猫

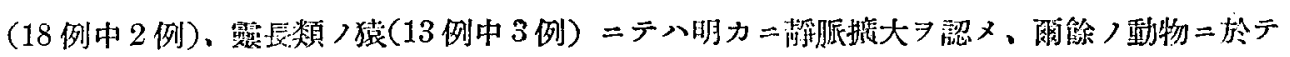

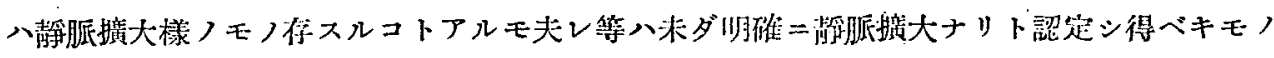

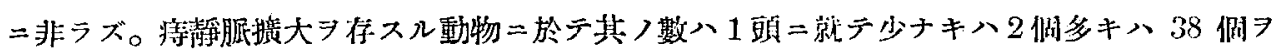

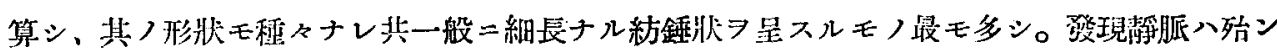

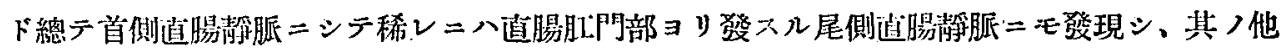

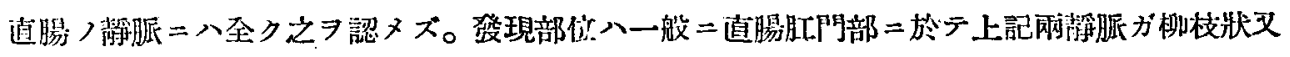

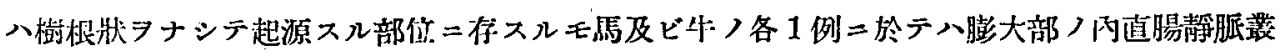


中ニ之ガ住在スルラ憼タリ。

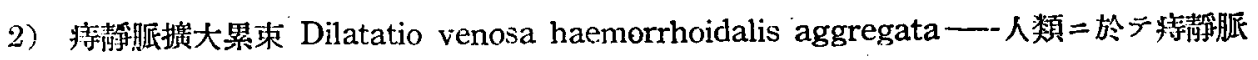

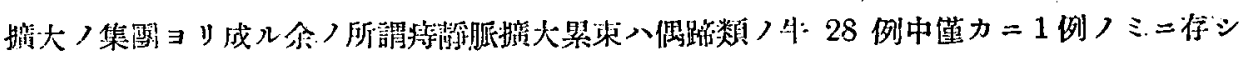
少入他ノ哺乳動物二於テハ全ク之

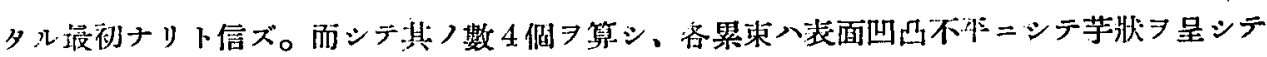

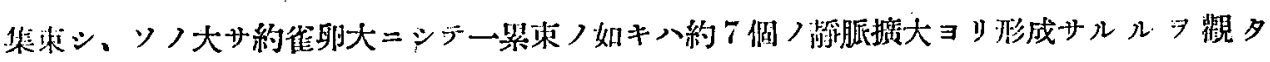

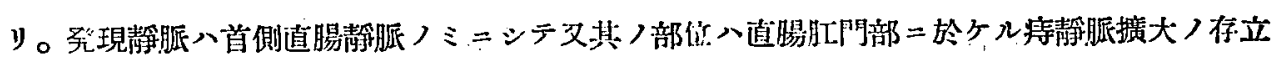
部低=一致ス。

\section{· 5. 結論}

以上ノ所見 7 結論スレバ次ノ如シ。

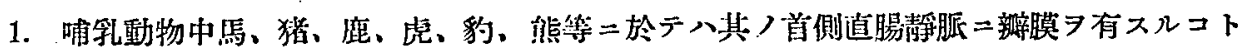
ヨ知見セリ。刨チソノ辦膜具倍つ關係ハ必ズシモ宗族發生史上ノ順序二则ルモノニ非ズシテ

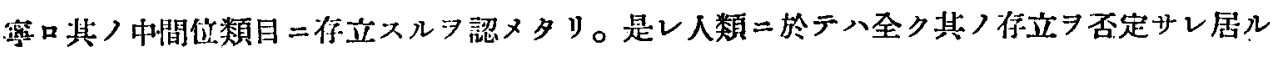
所ニシテ此等つ動物二於テ特簧つ形態卜請七得ベシ。

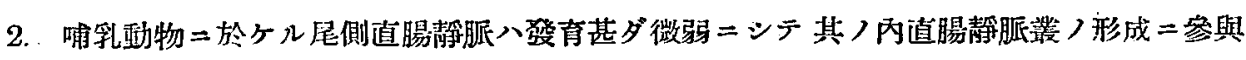
スルモノ八些ダ稀レナリ。是レ人類つ場合卜異ナル所ナリ。

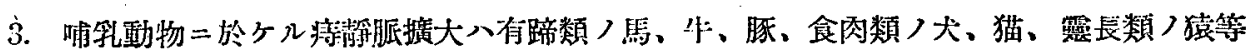

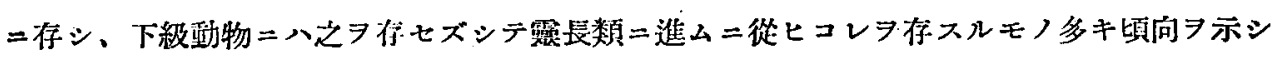

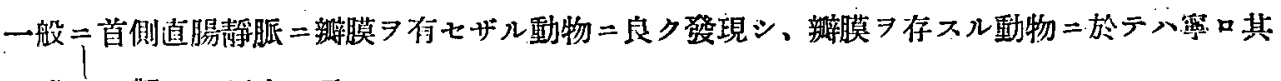

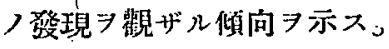

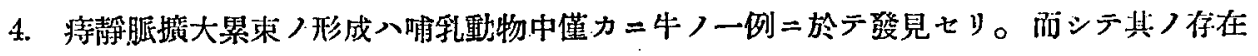

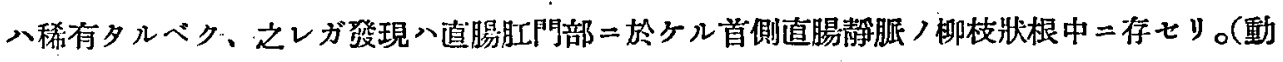
物痔核八後日發表セントス)。

\section{文献}

1) Ellenberger u. Baum : Systematische und topographische Anatomie des Hundes, Berlin 1891.

2) Quénu, M.: Étude sur les veines du rectum et de l'anus. Bull. de la Soc. anat., 1892.

3) Gegenbaur, C.: Vergleichende Anatomie der Wirbeltiere. 1898.

4) Storch, C. : Das Celluloid und seine Anwendung zur Injection von Blutgefässen. Zeitschr. f. Thiermed. 1899 .

5) Sieber, H. F. : Zur vergleichenden Anatomie der Arterien der Bauch-und Beckenhä̆hle bei den Haussäugetieren. Inaug.--Diss. Zürich 1903. 
6) Lehmann, W.: Über Bau und Entwickelung der Wand der hinterene Hohlven des Rindes und Venenklappen bei Pferd und Rind. Inaug.-Diss. Berlin 1908.

7) Schmitz, A. : Die Pfortader des Pferdes, Rindes und Hundes und inr mikroskopisches Verhalten beim Pferd. Inaug.-Diss. Dresden 1910.

8) Perényi, L.: Die hintere Hohlvene des Kaninchens nebst dessen Pfortadersystem. Inaug.-Diss. Budapest 1920.

9) Pohle, C.: Das Venensystem des Hundes. Inaug.-Diss. Dresden 1920.

10) Schimkewitsch, W.: Lehrb. der vergleichenden Anatomie der Wirbeltiere 1921.

1i) Martin, P.: Lehrbuch der Anatomie der Haustiere. 1923.

12) Bensley, B. A.: Practical anatomy of the rabbit. 1926.

13) Ellenberger u. Baum. : Handb. vergl. mikrosk. Anat. d. Haustiere. 1926.

14) Bradley, O. C. : Topographical Anatomy of the Dog. 1927.

15) Konaschko, P.: Zur Frage der Injection menschlichen Leichenmaterials mit KarminGelatinemasse. Zeitschr. f. Wissenschaftl. Mikrosk. u. f. mikroskop. Technik. 1927.

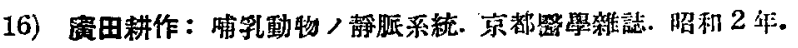

17) Romeis, B.: Gefäss-Injectionsmethoden. Taschenb, d. mikrosk. Technik. 1928.

18) Stromsten, F: Davison's Mammalian Anatomy with special reference to the Cat. 1931.

19) Bolk, Göppert, Kallius, Lubosch.: Handbuch der vergleichenden Anatomie der Wirbeltiere. Bd. 6. 1933.

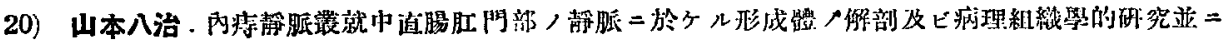

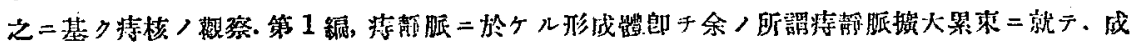

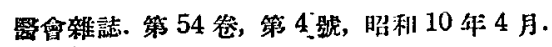

21) 谷律直俰：動物分類表. 昭和 12 尔 8 月.

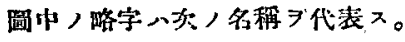

D. = Dilatatio venosa haemorrhoidalis aggregata.

$\mathrm{V} . \mathrm{ca} .=\mathrm{V}$. rectalis caudalis.

V.as. $=$ V. ascendens.

R.v. = Radix ventralis.

T.m. $=$ Truncus medius

V.c. $=V$. rectalis cranialis.

Vv.a. $=$ Vv. anales.

V.e. $=$ Venenerweiterung.

R.d. $=$ Radix dorsalis

T.d. = Truncus dexter.

T.s. $=$ Truncus sinister.

P.a. $=$ Pars analis recti.

P.am. = Pars ampullaris.

Ht. = Hauptstamm 
第一 一 圖

馬直腸 7 腹側正中斷シテ示セル內直腸靜脈叢 $\delta \quad 1 / 2$

R.v.

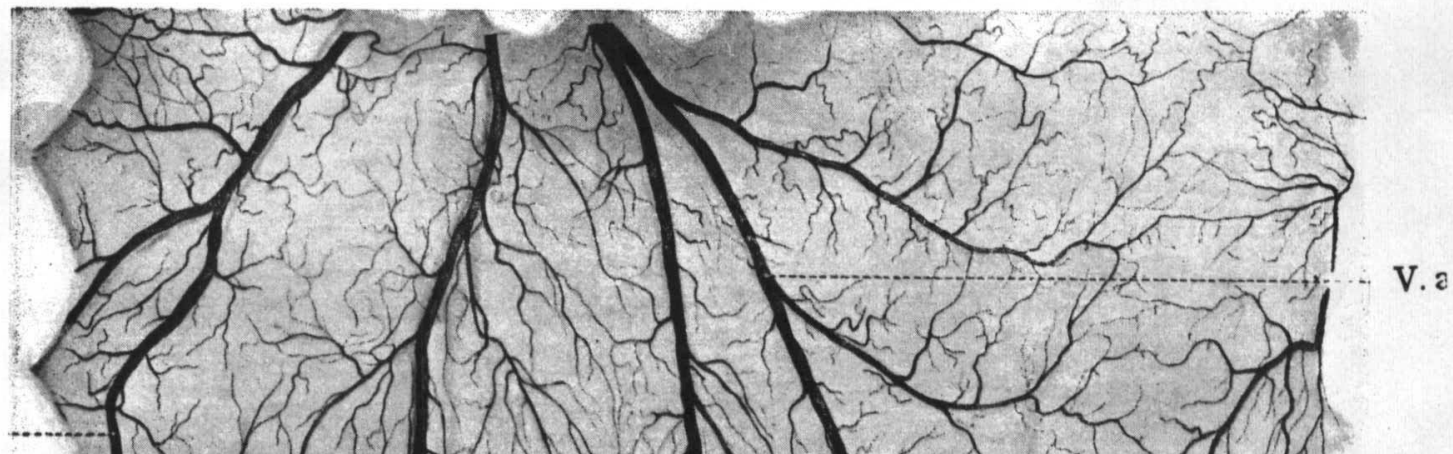

V.e.

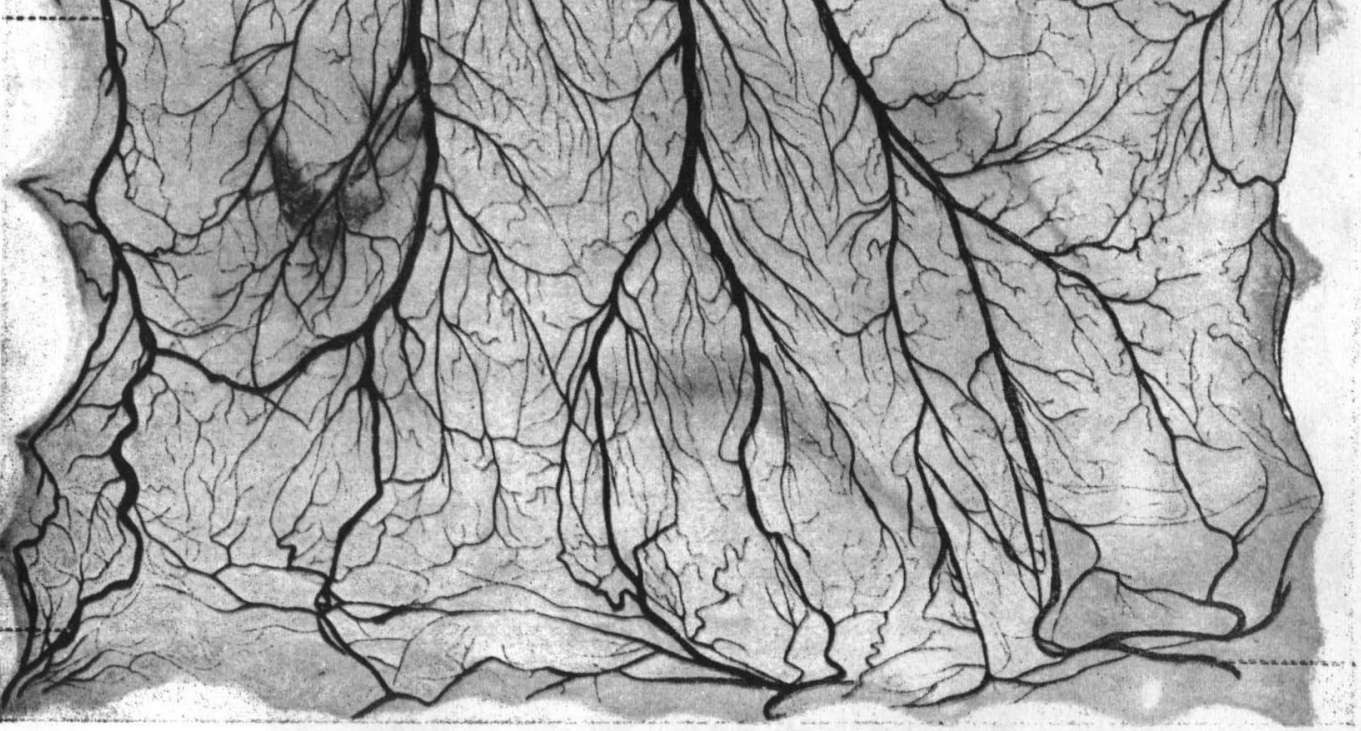

Vv.

第 二 圖

牛 內直腸静脈丵 $=$ 於ヶル痔靜脈擴大累束 $\& 1 / 2$

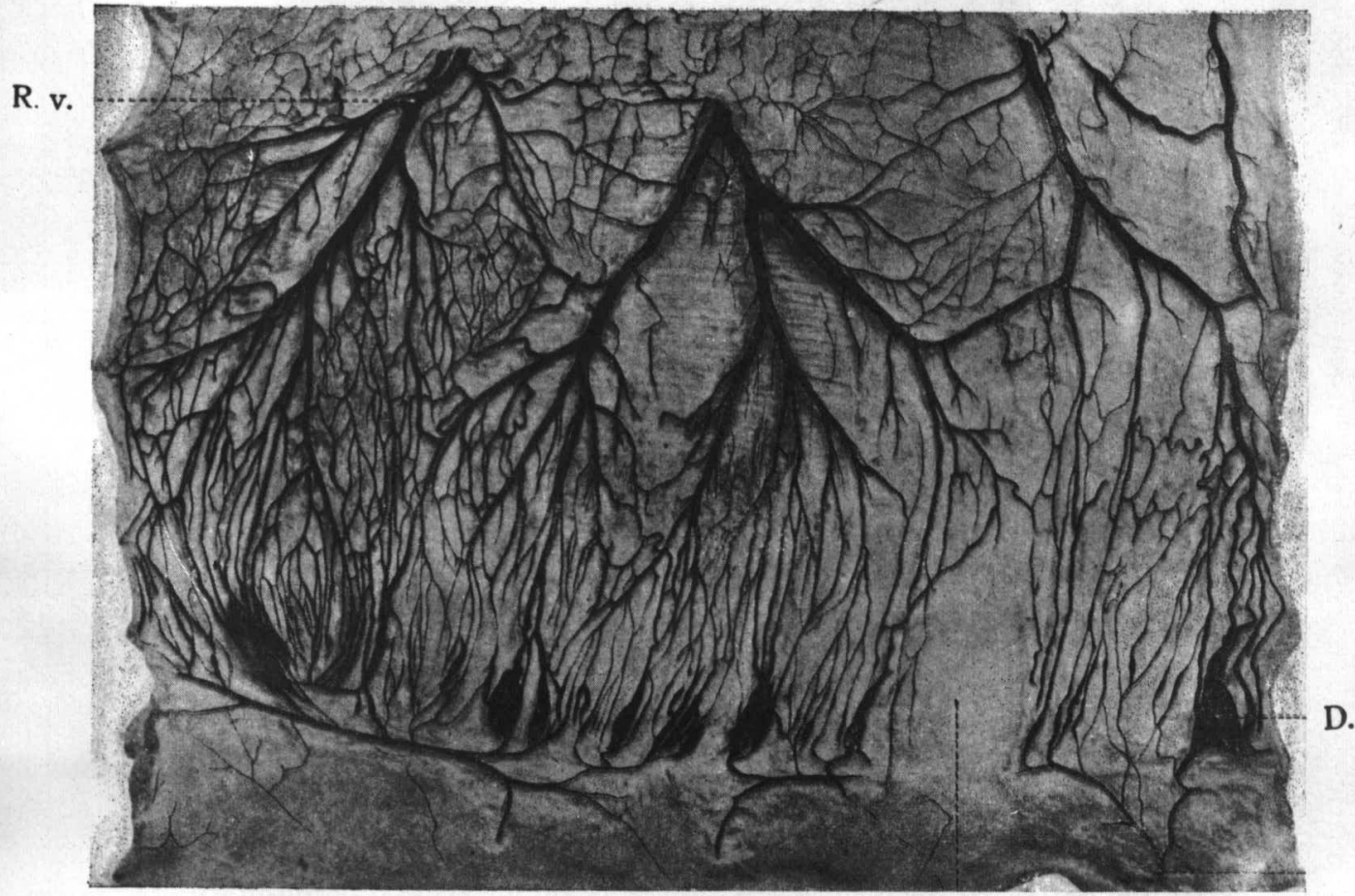

山本論交附圖

P. a.

H. Yamamoto 
第三圖

牛 粘膜面二於ケル靜脈叢 $\hat{\delta} 1 / 2$

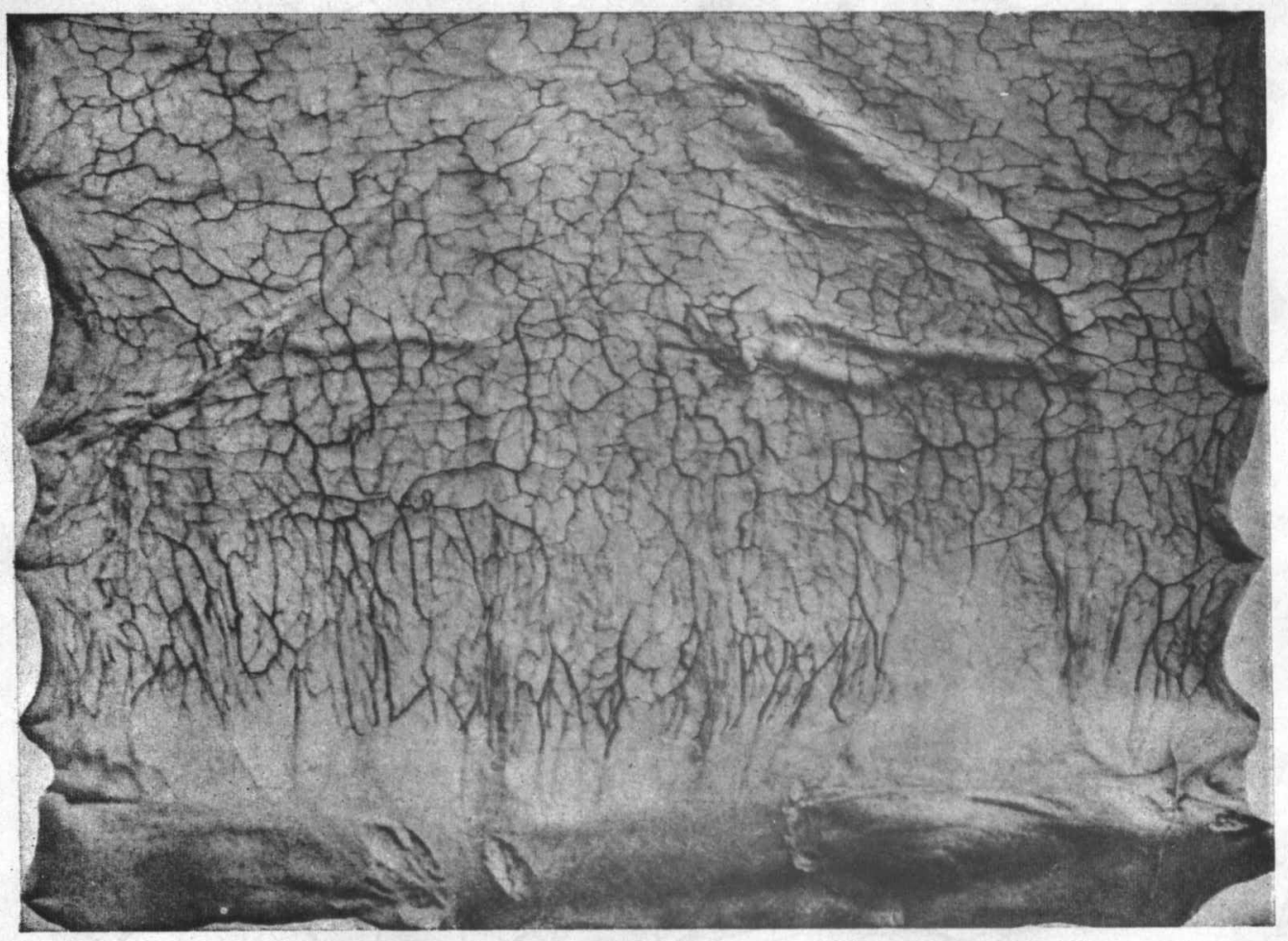

第四圖

羊 內直腸静脈丵 =静脈演大存七ズ ${ }^{2} / 3$

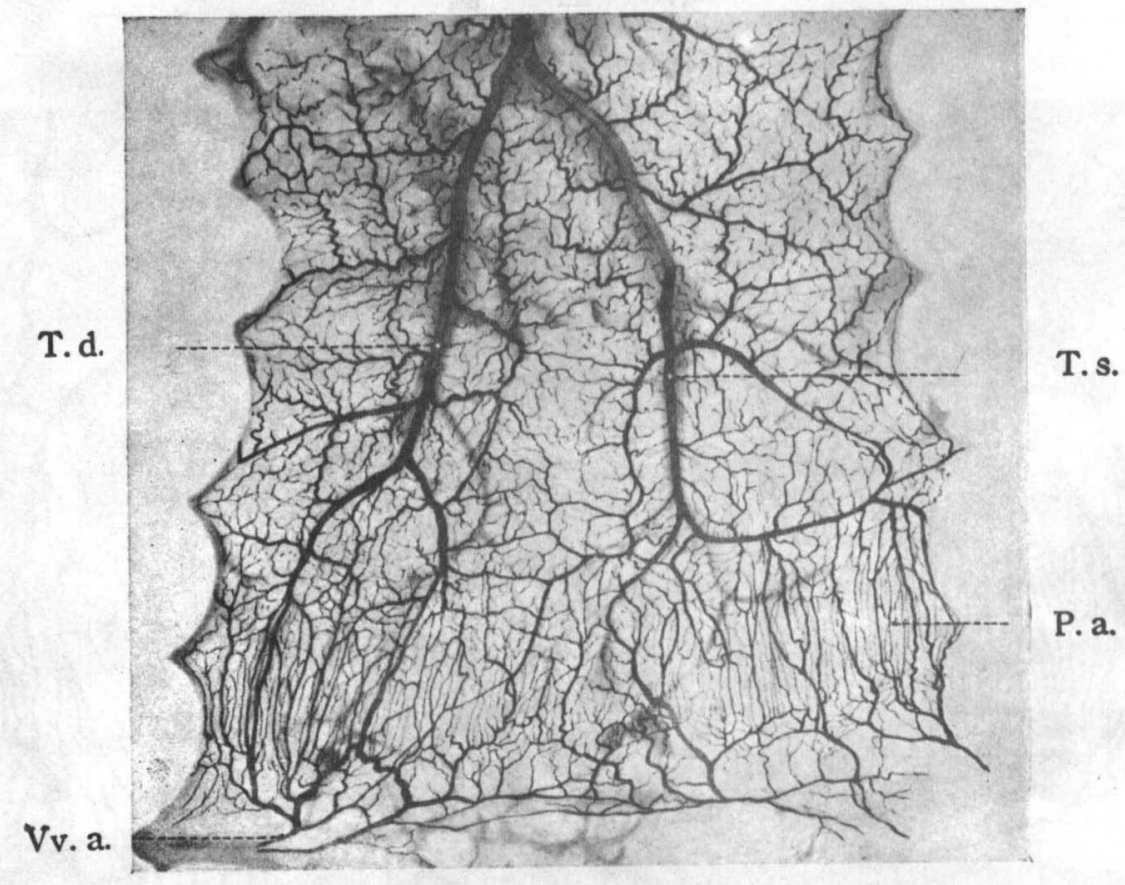


第五圖

山羊內直腸静胍叢。 $2 / s$

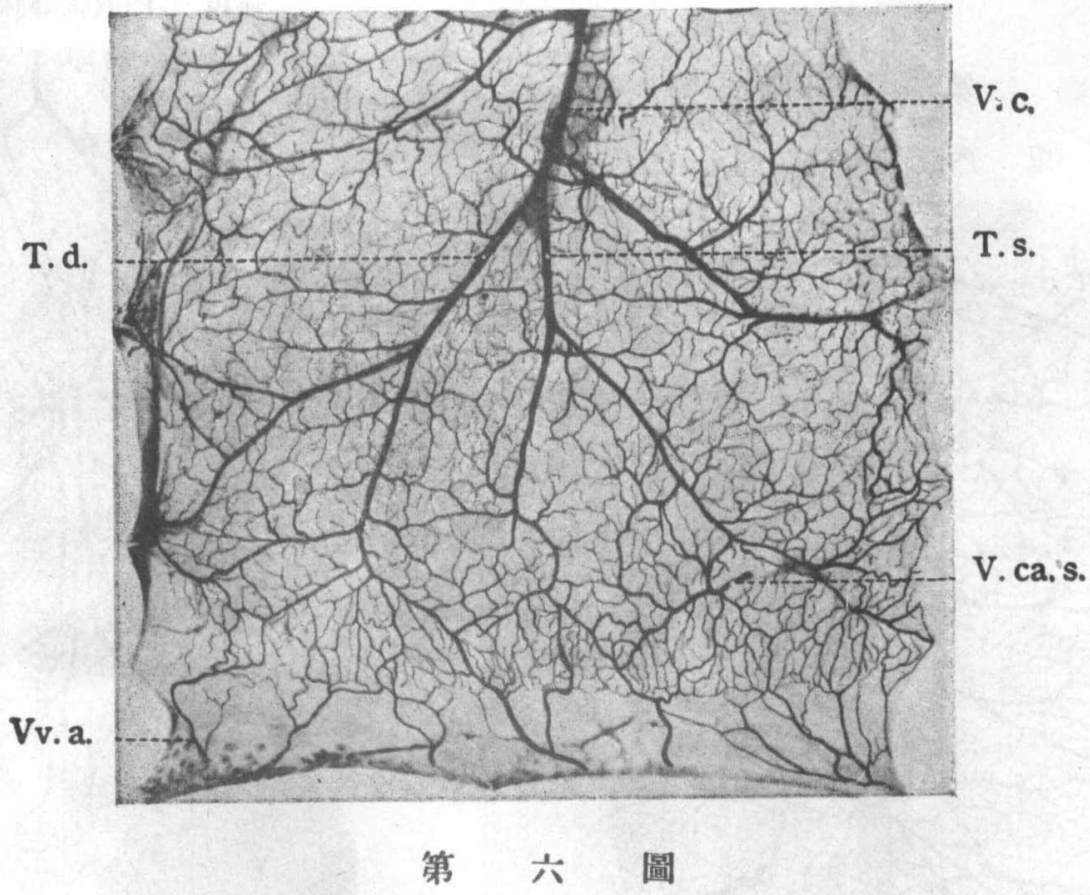

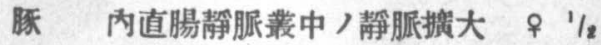

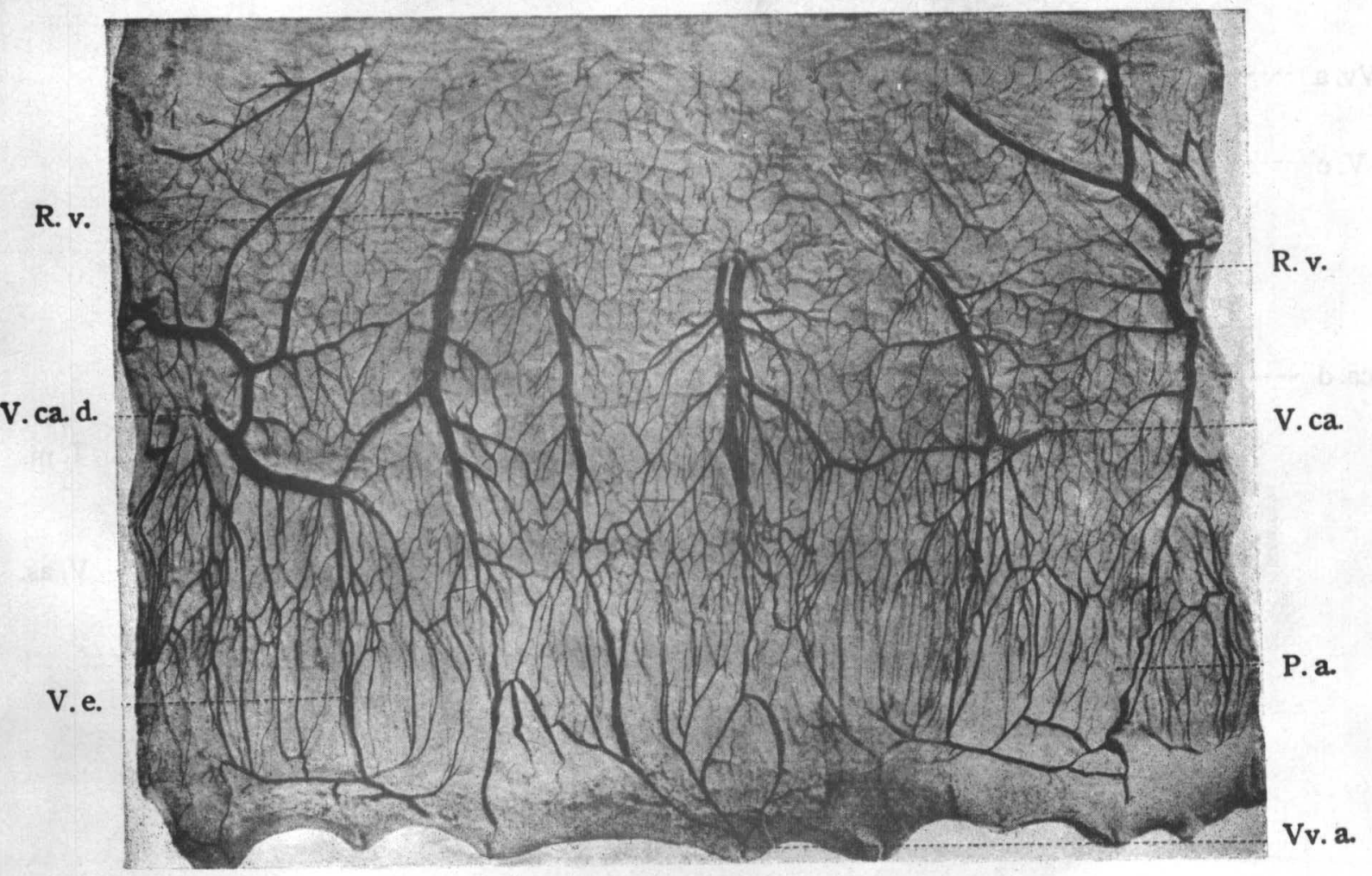



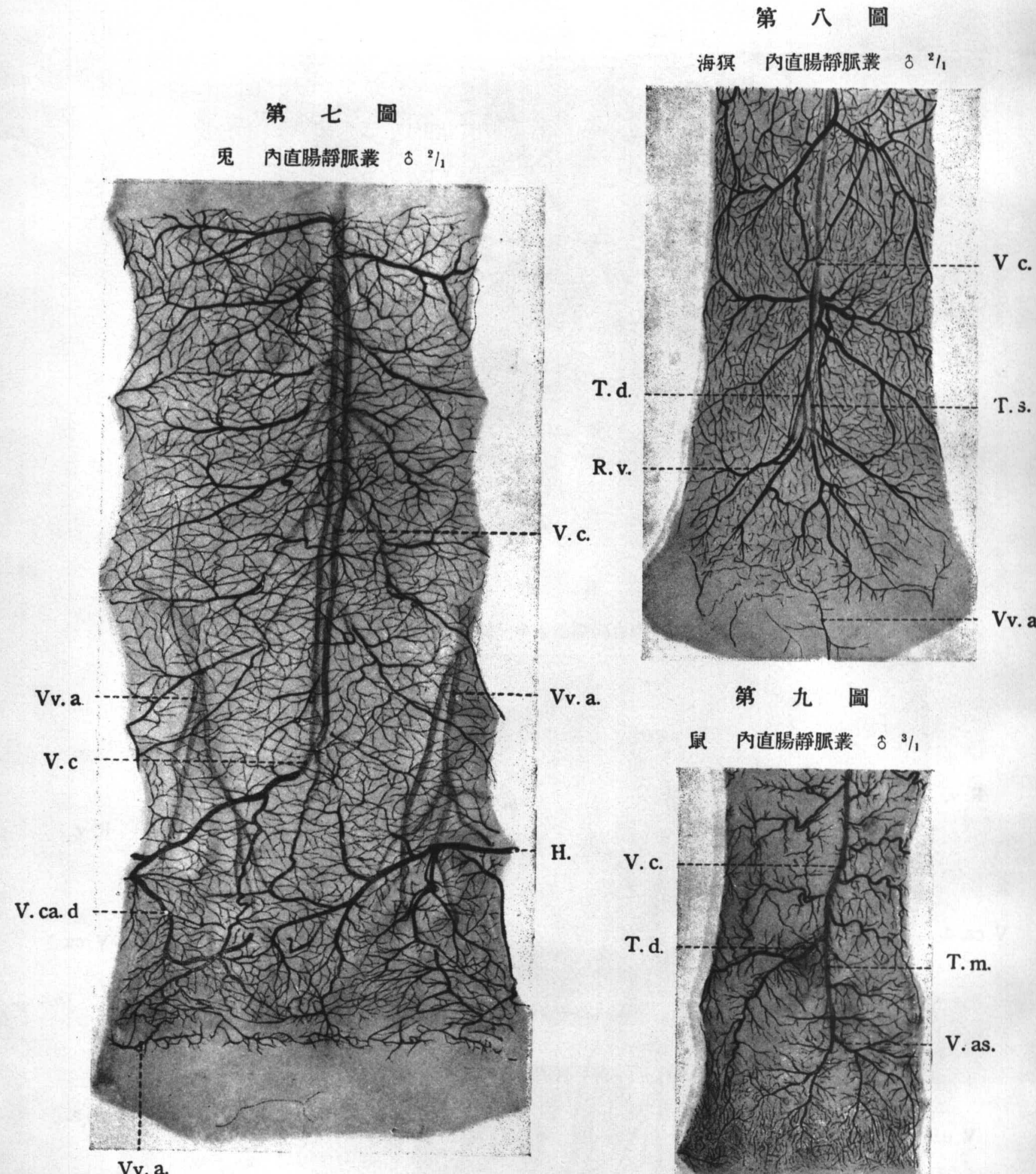

Vv. a.

第九 圖

鼠內直晹靜脈叢 $\delta 3 \%$

H.

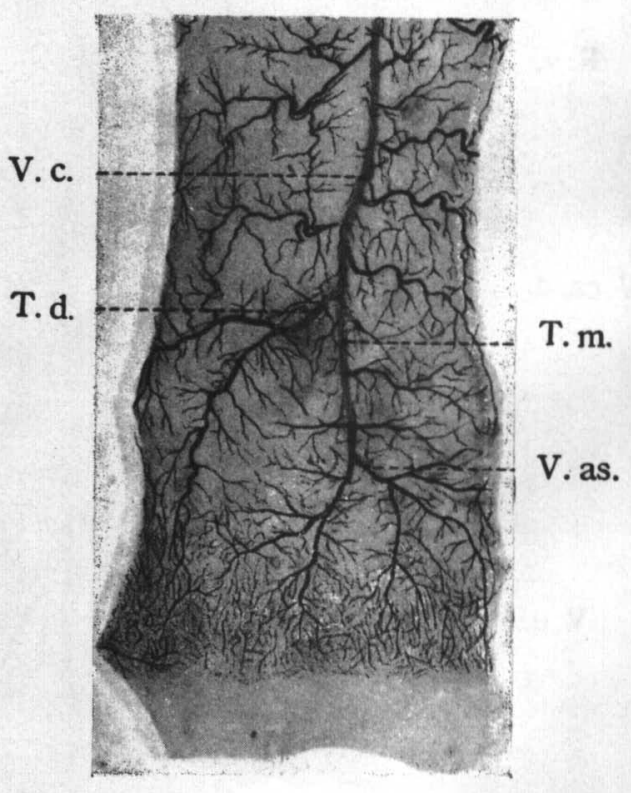



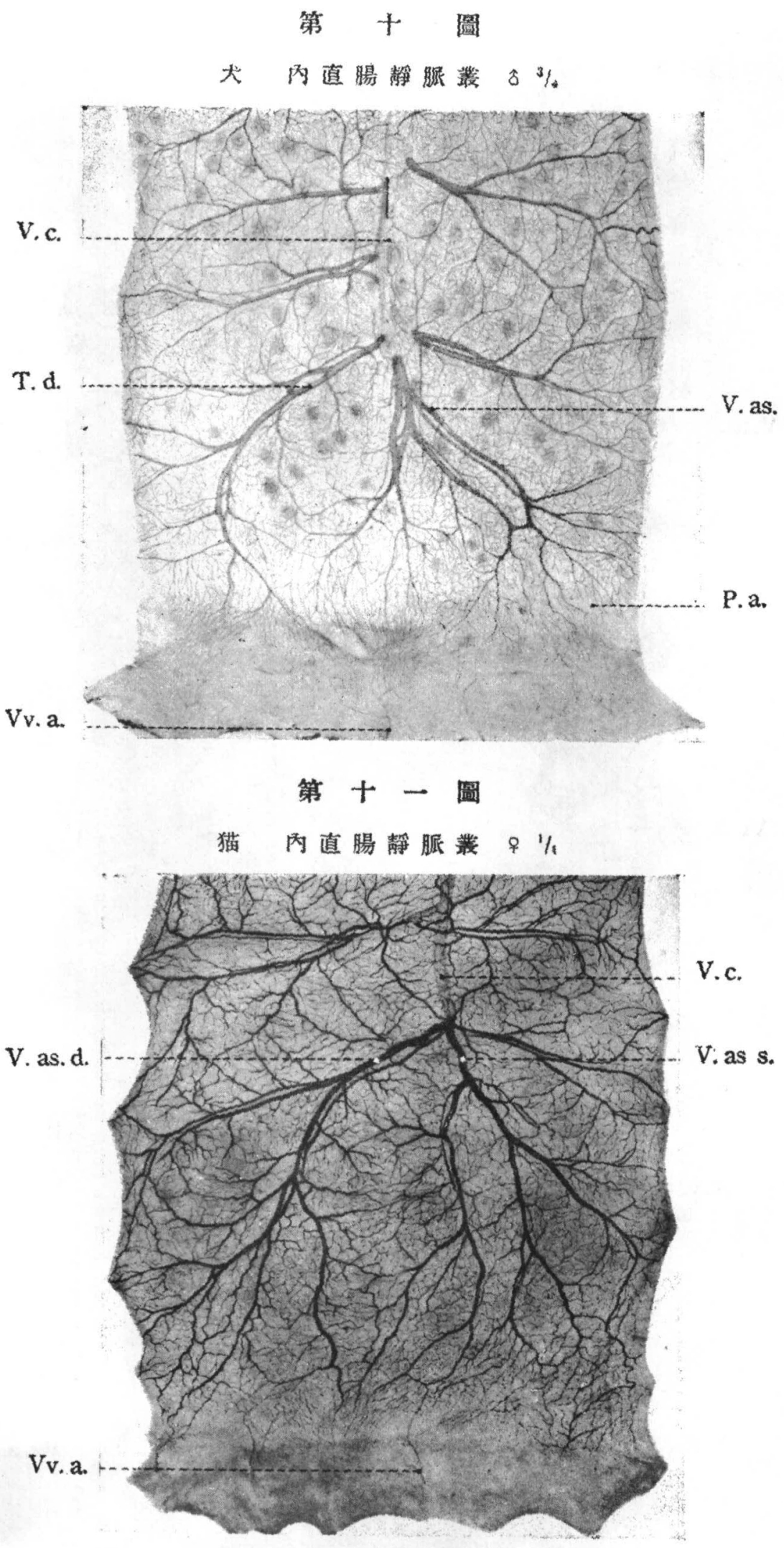


$$
\text { 第 十 二 圖 }
$$

虎內直腸靜脈對 $\delta 1 / 2$

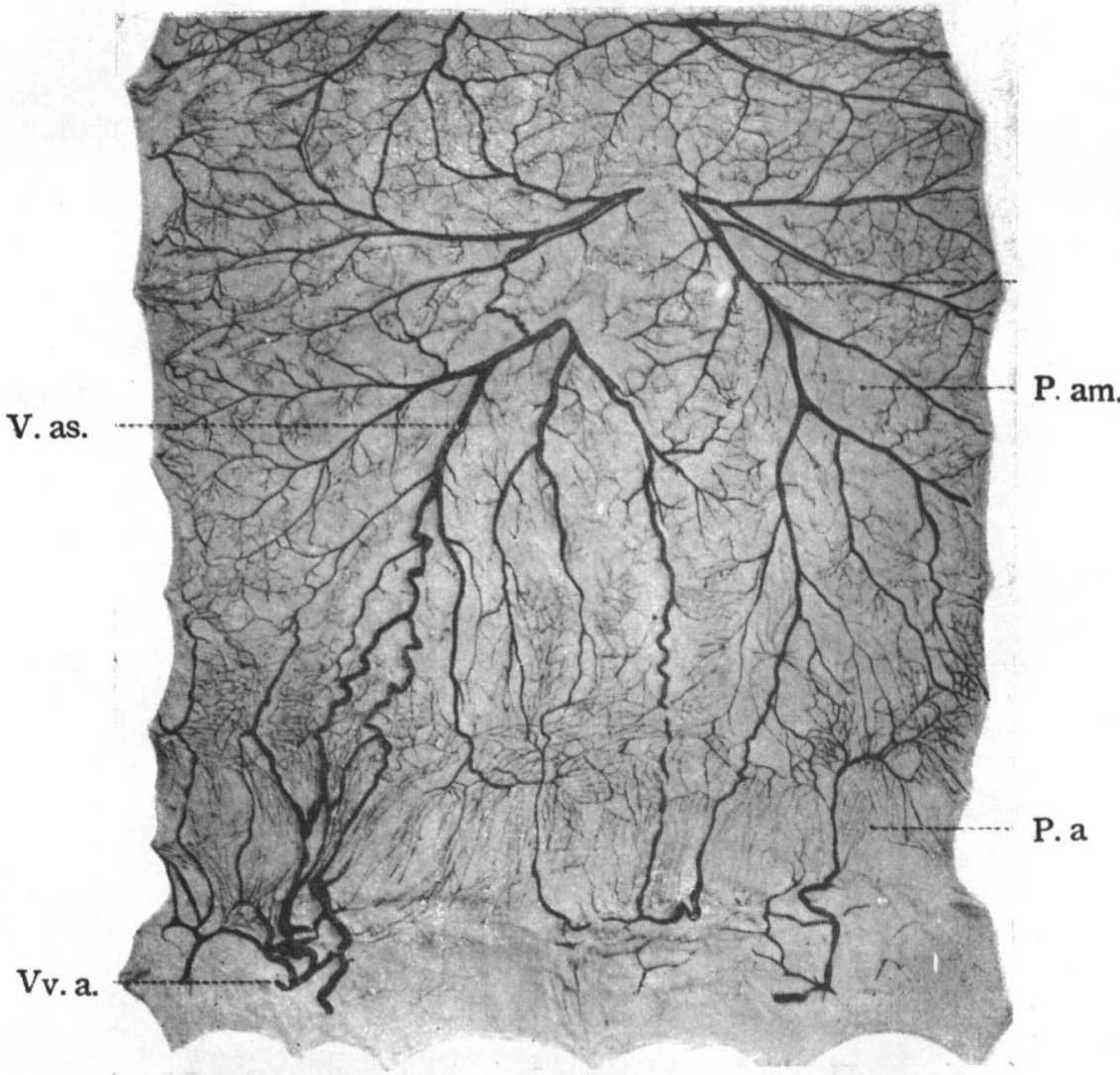

$$
\text { 第 } 十 \text { 三圖 }
$$

猿內直腸靜脈叢 $\hat{o} 1 \frac{1}{2}$

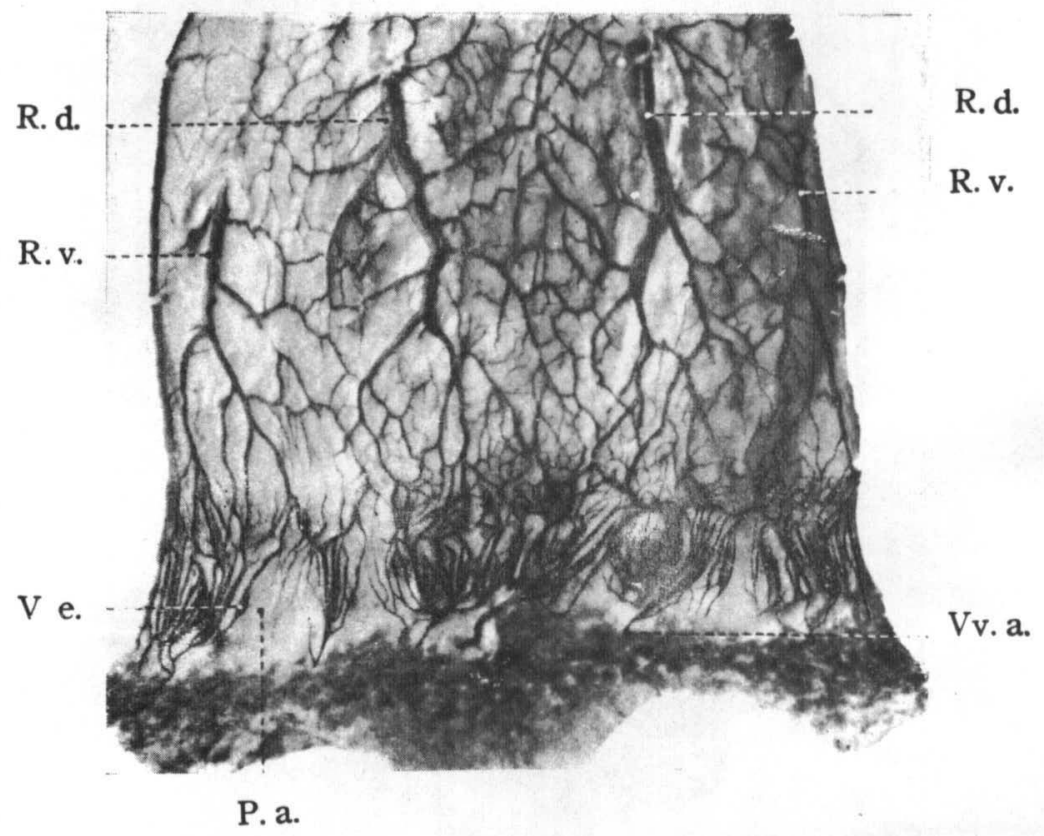




\section{Zeitschrift}

der

\section{Japanischen Proktologischen Gesellschaft}

Band I, Heft 2, Deż. 1940

Kurzer Auszüger aus den Originalmitteilungen

\section{Über den Plexus rectalis internus der Säugetiere, insbesodere die Dilatatio venosa haemorrhoidalis aggregata.}

Dr. Hatizi Yamamoto.

(Yamamoto-Byoin, Tokyo)

Das Resultat der Injektion von Teichmannscher variierter Loesung in die Venen des Rektums der verschiedenen Säugetieren laesst sich kurz wie folgt zusammenfassen:

1. Form des Rektums.

Da die Pars analis recti der. Saeugetiere im Durchmesser im allgemeinen etwas enger als Pars ampullaris ist, so sieht das Gesamtbild des Rektums zylindrisch oder spindelförmig aus.

2. Die Klappe der V. rectalis cranialis.

Dass es solche V. rectalis cranialis gibt, die mit der Klappe versehen ist, erst durch die Injektion zu meiner Kenntnis gekommen. Die Tiere, deren Venen mit Klappen versehen sind, soweit ich beobachtete, Ferissodactyla (Equus caballus); Artiodactyla (Cervus nippon und Sus leucomystax) und Carnivora (Felis tigris und Feris pardus). Und die Tiere, deren Venen ohne Klappen sind, hingenen Macropus giganteus von der Marsupialia, mytacoceti von der Cétacea; Bos taurus, Obis aries, Capra hircus, Sus scrofa var. domesticus von der Artiodactyla; Lepus brachyurus, Entamia asiticus, Cavia porcellus, Rattus norvegicus vön der Rodentia; Callotaria ursina, Zalophus lobatus von der Pinnipedea; Canis'familiaris, Vulpus japonicus, Nyctereutes procyonoides viverrinus; Mustela erminea nippon, Felis domestica von der Carnivora; und Simiae von den Primaten. Und was etwas unsicher ist, betrifft Erinaceus von der Insectivora; Lutra und Meles taxus von der Carnivora. Die Existenz der Klappen in dem Gebiet der V. rectalis cranialis, steht in Zusammenhang mit der Tierreihenfolge von niedriger 
Ordnung bis Primaten nicht. Vielmehr besteht sie unter den Tieren, die zur mittleren Ordnung gehören, während sie unter den Tieren niedriger Ordnung und von den Primaten nicht besteht.

Übrigens habe ich bei Injektion an 316 menschlichen Leichen niemals das Vorhandensein der Klapppen in der V. rectalis cranialis gefunden.

3. Plexus rectalis internus.

Der Plexus rectalis internus besteht im allgemeinen aus einem dichten venosen Plexus. Die Intensität und Form der Flexus sind mehr oder weniger verschieden nach der Tierarten. Es ist jedoch allen Tieren gemeinsam, dass der I lexus rectalis internus in der Pars analis recti etwas einen weidenzweigartigen und baumwurzelartigen Verlauf und der Flexus in der Pars ampullaris eine unregelmässige netzartige Form zeigt.

4. Vv. rectales.

a) V. rectalis cranialis. Nach meiner Untersuchung über das menschliche Material ist der Plexus rectalis internus ungefaehr in der Hälfte der Fälle aus den beiden Venen, V. rectalis cranialis und V. rectalis caudalis gebildet. Bei den Säugetieren hat die $V$. rectatis caudalis nur selten Teilnahme an der Bildung des Plexus rectalis internus. In fast allen Fällen ist derselbe anscheinend nur aus der $V$. rectalis cranialis gebildet. Und da die $V$. rectalis cranialis die groesste von den Venen des Mastdarmes ist, und andere Venen nur einen kleinen Teil des Plexus rectalis internus bildet, so könnte die $\mathrm{V}$. rectalis cranialis gleich die $\mathrm{Vv}$. rectales genannt werden.

Die V. rectalis cranialis in der Pars analis recti entstehen bei den Tieren weidenzweigförmig oder baumwurzelförmig, vereinigen sich bald zur V. ascendens von 2-8 Venen, im allgemeinen von 5 Venen. Dieselbe verlauft unter der Schleimhaut schraeg nach cranial und dorsalwärts bis sie die Muskelschicht in der Pars ampullaris durchbohrend aus dem Rektum heraus tritt. Und gleich darauf fliessen die Radices zum Truncus zusammen, und ferner fliessen die Truncus zum Hauptstamm zusammen.

Um von der groesseren Zahl von gleichen Typen der Reihe nach zu nennen, wie die Radix und Truncus der V. rectalis cranialis zusammenfliessen, so koennen sie in 10 Typen eingeteilt werden. Und bei den Primaten ist die Vereinigung verhaeltnismaessig verwickelt und zwar vereinigt sich der Radix ventralis mit dem Radix dorsalis je zum Truncus sinister oder Truncus dexter ferner vereinigt sich der Truncus. sinister mit dem Truncus dexter zum Hauptstamm der V. rectalis cranialis.

b) V. rectąlis caudalis. Die Vene entspringt meistens aus dem Plexus rectalis externus in der Pars ampullaris oder aus dem Plexus rectalis internus und externus, nur wenige derselben entspringen gleich wie der Ursprung der V. rectalis cranialis in der Pars analis recti, verlaufen na $h$ cranialwärts, treten die Muskelschicht durchbohrend aus dem Rektum heraus, Ferner nehmen sie die aus dem M. sphincter ani und dem M. levator ani kommenden Venen auf und fliessen in die V. ilica interna ein. Nach der Literatur die Angabe über das Vorhandensein der Vv. rectales craniales et caudales bei gewisse Ordnung der Tiere ganz fehlt, während bei anderen Tieren V. rectalis caudalis fehlt. 
Es erweckt deshalb den Eindruck, dass keine Aufmerksamkeit daruaf geschenkt worden ist. $\mathrm{Da}$ ich dachte, dass diese Venen eigentlich anatomisch sowie klinisch sehr interessant und sehr wichtig sei, so stellte ich Untersuchung darüber an. Dabei fand ich, dass sie bei jedem Tiere immer vorhanden ist. Gewisse Venen fliessen in die Venen der Bauchwand und des urogenitalen Crganes ein. Es finden sich manchmal auf einer Seite ihrer drei oder vier. Natürlich sind hierhei feine Venen nicht genau gezählt worden. Wenn solche feine Venen ausgenommen werden, so bleibt es nicht anders zu sagen, dass ihr Vorhandensein auf einer Seite oder auf beiden Seiten unbestimmt ist.

c) Vv. anales. Diese Venen entspringen in der Pars analis recti und bilden den Plexus venosus subcutaneus analis. Von da wenden sie sich lateral und erreichen die Fossa ischiorectalis. Hier vereinigen sie sich einerseits mit den Venen, die aus dem Plexus rectalis internus entspringen und gleich den $M$. sphincter ani durchbohren, zuweilen auch mit den Venen, die von dem caudalen Teil des Rektums entspringen, gewoehnlich zu zwei oder drei Venen ( 1 bis 4 ) und muenden in die V. pudendalis interna. Welche von ihnen fliessen auch in die $V$. caudalis lateralis superficialis oder in die V. glutaea inferior ein.

d) Ramus rectalis der V. sacralis media kommen nur selten bei Tieren vor. Wenn er vorhanden ist, so entspringt er meistens von dem dorso-caudalen Teil des Rektums, aber zuweilen aus dem Plexus rectalis internus, durchbohrt die Muskelschicht, wendet sich nach dorsalwärts und verbindet sich mit der V. sacralis. Aber bei meiner Untersuchung an menschlichen Leichen entspringt er obwohl wenige Fälle gleich wie der Verlauf der V. rectalis cranialis aus der Pars analis recti läuft eine Weile unter der Schleimhaut nach cranialwärts und tritt gleich den Muskelschicht durchbohrend aus dem Rektum heraus, wohingegen ich bei Tieren einen solchen Fall noch nicht getroffen habe.

\section{Anorectale Venenerwiterung.*}

Was das Vorhandensein der Venenerweiterung des Rectums bei Tieren betrifft, so hat 1892 ein Franzose Quenu in einer 'Abhandlung Etude sur les veines du rectum et de anis' angegeben, dass weder er bei Injection in die $V_{v}$. rectales des Pferdes und des Hundes noch sein Freund $M$. Lamothe in die $V_{v}$. rectales eines Hasen in dem Plexus rectalis eine Bildung wie die Venenerweiterung hat befinden koennen.

Aber nach meiner Untersuchung habe ich in dem Plexus rectalis internus bei Equus caballus von der Perissodactyla ( 3 mal unter 22 Fällen), bei Bos taurus von der Artiodactyla ( 8 mal unter 28 Fällen), bei Sus serofa ( 6 mal unter 18 Fällen), bei Canis familiaris ( 3 mal unter 21 Fällen), bei Fels domestica ( 2 mal unter 18 Fällen) von der Carnivora; und bei Simiae ( 3 mal 13 Fällen) von dem Primates die Venenerwniterung deutlich befunden. Bei den sonstigen Tieren wird zwar etwas der Venenerweiterung Aehnliches befunden, aber es ist noch nicht solches, das klar als Venenerweiterung anerkannt werden kann. Bei den Tieren, bei denen die Venenerweiterung vorhanden ist, zählt sie pro Stück wenigstens 2 und meistens 38 . Und

* oder Venenerweiterung des Rectums. 
sie findet sich in verschiedenen Formen, aber im allgemeinen bietet s'e eine längliche dünne Spindelform. Die Entstehungsvene ist fast alle die V. rectalis cranialis, nur selten entsteht sie in der $\mathrm{V}$. rectalis caudalis, die in der Pars analis recti entspringt, und in den sonstigen $V v$. rectales wird sie nicht befunden. Und was die Entstehungsstelle betrifft, so ist sie in der Pars analis recti bei den oben erwaehnten Venen, die als feine weidenzweig- oder baumwurzelförmig ursprünglich entstehen, aber besonders bei Equis caballus und Bos tau us habe ich sie je in einem Falle in dem Plexus rectalis intennus vorhanden gesehe.. In kurze Worten, kommt die Anorectale Venenerweiterung bei der Dactyla, der hoeheren Canirvola und den Primaten vor. Im allgemeinen entsteht Venenerweiterung bei den Tieren, deren V. rectalis cranialis keine Klappen hat, waehrend bei den Tieren, deren Plexus rectalis cranialis solche Klappen hat, die Tendenz herrscht, ihre Entstehung nicht zu zeigen.

6. Dilatatio venosa haemorrhoidalis aggregata.

Die von mir sogenannte Dilatatio venosa haemorrhoidalis aggregata, wobei die Venenerweiterungen aggregieren, hat sich bei Bos taurus von der Artiodactyla unter 28 Fällen nur ein einziges Mal gefunden und bəi den sonstigen Säugetieren hat sie gar nicht finden werden koennen. Dies, glaube ich, wuerde ein einziger Fall dafür sein, dass ich bei den Säugetieren zum ersten Mal ein spezifisches dilatatives Aggregat bestätigt habe. Und es besteht aus 4 an Zahl. Jedes Aggregat ist spatzeneigross, und stellt unebene süsse Kartoffelförmig dar. Ein Aggregat besteht gewoehnl:ch aus 7 Venenerweiterungen. Die Entstehungsvene ist nur die $V$ rectalis cranialis und die Entstehugistelle stimmt mit der Venenerweiterung in der Pars analis recti überein. 